Joelma Moura-Alvarez

Detecção molecular e diagnóstico diferencial de vírus entéricos em criações de perus comerciais 
Joelma Moura-Alvarez

\section{Detecção molecular e diagnóstico diferencial de vírus entéricos em criações de perus comerciais}

Dissertação apresentada ao Programa de PósGraduação em Patologia Experimental e Comparada da Faculdade de Medicina Veterinária e Zootecnia da Universidade de São Paulo para obtenção do título de Mestre em Ciências

Departamento:

Patologia

Área de concentração:

Patologia Experimental e Comparada

Orientador:

Prof. Dr. Antonio José Piantino Ferreira 
Autorizo a reproduçåo parcial ou total desta obra, para fins acadêmicos, desde que citada a fonte.

DADOS INTERNACIONAIS DE CATALOGAÇĂO-NA-PUBLICAÇĀO

(Blblioteca Virginie Buff o'Ápice da Faculdade de Medicina Veterinária e Zootecnla da Universidade de Sso Paula)

\begin{tabular}{|c|c|}
\hline \multirow[t]{5}{*}{$\begin{array}{l}\text { T.2439 } \\
\text { FMVZ }\end{array}$} & $\begin{array}{l}\text { Moura-Alvarez, Joelma } \\
\text { Deteç̧̃ó molecular e diagnóstico diferencial de vírus entéricos em } \\
\text { criaçốes de perus comerciais / Joelma Moura-Alvarez. - } 2011 \text {. } \\
118 \text { p. : il. }\end{array}$ \\
\hline & $\begin{array}{l}\text { Dissertação (Mestrado) - Universidade de Säo Paulo. Faculdade de } \\
\text { Medicina Veterinária e Zootecnia. Departamento de Patologia, São Paulo, } \\
\text { 2011. }\end{array}$ \\
\hline & $\begin{array}{l}\text { Programa de Pós-Graduação: Patologia Experimental e Comparada. } \\
\text { Área de concentraçăo: Patologia Experimental e Comparada. }\end{array}$ \\
\hline & Orientador. Prof Dr. Antonio José Piantino Ferreira. \\
\hline & $\begin{array}{l}\text { 1. Perus. 2. Virus. 3. Enterites. 4. Reação em cadeia por polimerase. } \\
\text { 5. Diagnóstico. I. Título. }\end{array}$ \\
\hline
\end{tabular}




\section{CERTIFICADO}

Certificamos que o Projeto intitulado "Detecção molecular e diagnóstico diferencial de vírus entéricos em perus comerciais", protocolado sob o $n^{\circ}$ 1943/2010, utilizando 78 (setenta e oito) amostras de intestino de peru, sob a responsabilidade do Prof. Dr. Antonio José Piantino Ferreira, está de acordo com os princípios éticos de experimentação animal da "Comissão de Ética no uso de animais" da Faculdade de Medicina Veterinária e Zootecnia da Universidade de São Paulo e foi aprovado em reunião de 26/05/2010.

We certify that the Research "Molecular detection of enteric viruses in commercial turkey flocks", protocol number 1943/2010, under the responsibility Prof. Dr. Antonio José Piantino Ferreira, agree with Ethical Principles in Animal Research adopted by "Ethic Committee in the use of animals" of the School of Veterinary Medicine and Animal Science of University of São Paulo and was approved in the meeting of day 05/26/2010.

São Paulo, 27 de maio de 2010

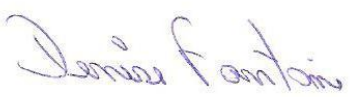

Profa. Dra. Denise Tabacchi Fantoni

Presidente 


\section{FOLHA DE AVALIAÇÃO}

Nome: MOURA-ALVAREZ, Joelma

Título: Detecção molecular e diagnóstico diferencial de vírus entéricos em criações de perus comerciais

Dissertação apresentada ao Programa de Pós-Graduação em Patologia Experimental e Comparada da Faculdade de Medicina Veterinária e Zootecnia da Universidade de São Paulo para obtenção do título de Mestre em Ciências

Aprovado em:

Banca Examinadora

Prof. Dr. Instituição:

Julgamento Assinatura:

Prof. Dr. Instituição:

Julgamento Assinatura:

Prof. Dr. Instituição:

Julgamento Assinatura: 


\section{DEDICATÓRIAS}

À Deus,
Pelo amor, luz, sabedoria e sustentação nos momentos de fraqueza.

Aos meus pais Joel e Nizete,

Por seu amor, confiança e apoio constante. Por me mostrarem o caminho e ainda ajudar a trilhar. Nada seria possível sem vocês.

Ao meu irmão Alexandre,

Pelo apoio emocional e cuidado. Obrigada pela amizade e carinho.

Ao meu marido Felipe,

Pela compreensão, carinho e conforto diários. Você é minha terra firme.

Ao meu filho Daniel,

Por ter nascido para me proporcionar um amor maior do que eu podia imaginar.

Obrigada por seus sorrisos diários e pelas noites de sono.

Você é a minha motivação, você é minha vida. 


\section{AGRADECIMENTOS}

Ao Prof. Dr. Antonio José Piantino Ferreira por me acolher no Laboratório de Ornitopatologia, demonstração constante de confiança, orientação científica, profissional e pessoal, e ainda pela enorme paciência em momentos de dificuldade.

À Dra. Elizabeth Santin que me despertou o interesse científico e me orientou o caminho a seguir na vida acadêmica e profissional.

Ao meu amigo Jorge que me transmitiu sem restrições todo o seu conhecimento científico, cujos conselhos foram muito valiosos, não somente no trabalho do laboratório, mas para a vida.

À Dra. Claudete por sua colaboração e total disponibilidade em sanar dúvidas, não somente neste estudo, mas em qualquer questão durante o trabalho no laboratório de Ornitopatologia.

Aos meus amigos e colegas do Laboratório de Ornitopatologia: Camila, Dennis, Elena, Lidiane, Liliana, Luciana Alegretti, Luciana Scanavini, Luís, Maria Eugênia, Gabriele e Maurício, pela convivência harmoniosa e colaboração.

Aos docentes da Faculdade de Medicina Veterinária e Zootecnia, Instituto de Ciências Biomédicas e Instituto de Matemática e Estatística pela contribuição para meu crescimento profissional e pessoal.

Às secretárias Cristina, Silvia, Cláudia, Dayse e Lázara pelo valioso apoio.

À Brasil Foods pelo envio das amostras utilizadas neste estudo.

À Dra. Erica Spackman pelo envio de amostras para auxílio no trabalho.

À todos aqueles que direta ou indiretamente colaboraram na realização deste projeto.

À Universidade Federal do Paraná

Pela minha formação e despertar o interesse científico.

À Universidade de São Paulo

Pelo acolhimento e oportunidade de iniciar este nova caminhada.

À Capes pelo auxílio financeiro cedido para a realização deste mestrado. 


\section{EPÍGRAFE}

"A patogênese de doenças virais entéricas é uma entidade complexa. Da mesma forma, a etiologia de uma doença entérica é igualmente complexa".

Donald L. Reynolds, 2003 


\section{RESUMO}

MOURA-ALVAREZ, J. Detecção molecular e diagnóstico diferencial de vírus entéricos em criações de perus comerciais. [Molecular detection and differential diagnostic of enteric viruses affecting commercial turkey flocks]. 2011. $118 \mathrm{f}$. Dissertação (Mestrado em Ciências) - Faculdade de Medicina Veterinária e Zootecnia, Universidade de São Paulo, São Paulo, 2011.

Setenta e seis amostras intestinais de lotes de perus apresentando ou não sinais clínicos de enterite foram avaliadas quanto à presença de adenovírus grupo 1 (TAV), vírus da enterite hemorrágica dos perus (HEV), astrovírus tipo 1 e 2 (TAstV-1 e TAstV-2), coronavírus dos perus (TCoV), reovírus, rotavírus e vírus da nefrite aviária (ANV) através da reação em cadeia da polimerase. Os resultados obtidos foram analisados quanto à região geográfica de origem das amostras, idade das aves e presença de sinais clínicos nos lotes. Foi detectada elevada positividade das amostras para pelo menos um vírus (93,4\%), e grande número de amostras com associações de mais de um vírus $(69,7 \%)$. Santa Catarina foi o estado com maior média de número de vírus detectados em associação nas amostras $(3,14)$ e Goiás o estado com menor média $(1,73)$. As amostras provenientes de aves em fase inicial de criação (1 a 4 semanas de idade) tiveram média de 3,20 vírus detectados por amostra, e $85 \%$ de detecção de TAstV-1 e TCoV (os mais frequentes), enquanto que na fase de terminação (5 a 18 semanas) foi observada menor média de vírus associados nas amostras $(2,41)$, e os agentes mais detectados foram TAstV-1 $(57,1 \%)$ e rotavírus $(51,8 \%)$, no entanto, todos os vírus apresentaram menor frequência na fase de terminação do que na inicial, com exceção do TAV e reovírus. Quando os sinais clínicos estavam presentes todos os vírus foram detectados em maior percentual (sendo TAstV-1, TAstV-2 e TCoV os mais frequentes) do que nos lotes sem sinais clínicos, onde TAstV-1 e rotavírus foram os mais frequentes. Estudos posteriores são necessários para a compreensão do papel de cada vírus no desenvolvimento de enterites.

Palavras-chave: Perus. Vírus. Enterites. Reação em cadeia por polimerase. 
MOURA-ALVAREZ, J. Molecular detection and differential diagnostic of enteric viruses affecting commercial turkey flocks. [Detecção molecular e diagnóstico diferencial de vírus entéricos em criações de perus comerciais]. 2011. $118 \mathrm{f}$. Dissertação (Mestrado em Ciências) - Faculdade de Medicina Veterinária e Zootecnia, Universidade de São Paulo, São Paulo, 2011.

Intestinal samples from seventy-six Brazilian turkey flocks affected or not with intestinal disorders were evaluated for the presence of Adenovirus group 1 (TAV), hemorrhagic enteritis virus (HEV), Astrovirus type 1 and 2 (TAstV-1 e TAstV-2), turkey Coronavirus (TCoV), Reovirus, Rotavirus and avian nephritis virus (ANV) using the polimerase chain reaction. Geographic location, age of the flocks and the presence of clinical signs were analyzed in order to find a relationship with the viral detection. A high frequency of positive samples for at least one virus was observed $(93,4 \%)$ and $69,7 \%$ of the samples showed an association of more than one agent. The highest average number of viruses detected in association $(3,14)$ was found in the state of Santa Catarina and Goias showed the lowest average $(1,73)$. An average of 3,20 viruses per sample was detected in poults in initial phase of the production cycle ( 1 to 4 weeks of age), and TAstV- 1 and TCoV were detected in $85 \%$ of the samples (the most frequent viruses), while the terminanting phase (5 to 18 weeks) showed lower average number of viruses in association $(2,41)$, and the most frequent viruses were TAstV-1 (57,1\%) and rotavírus $(51,8 \%)$. However, all the viruses were detected more frequently in the initial phase rather than in the terminating phase, in exception of TAV and reoviruses. A higher detection of the viruses was observed in poults with clinical signs (as TAstV-1, TAstV-2 and TCoV were the most frequent) compared to normal birds (as TAstV-1 and rotavirus were the most frequent). Furher researches should focus on the description and comprehension of the role of each virus, and the different combinations of viruses, in the development of enteric disease.

Keywords: Turkeys. Virus. Enteritis. Polimerase chain reaction. 


\section{LISTA DE FIGURAS}

Figura 1 - Eletroforese dos produtos de PCR correspondentes ao gene hexon do TAV. Coluna A: Amostra de campo; B: Controle positivo; C: Controle negativo; D: Padrão de peso molecular (Ladder 100 pb, LGC biotecnologia $\AA$ ).

Figura 2 - Eletroforese dos produtos de PCR correspondentes ao gene hexon do HEV. Coluna A: Amostra de campo negativa; B: Controle positivo; C: Controle negativo; D: Padrão de peso molecular (Ladder 100 pb, LGC biotecnologiaß).

Figura 3 - Eletroforese dos produtos de PCR correspondentes ao gene da polimerase do TAstV-1. Coluna A: Amostra de campo; B: Controle positivo; C: Controle negativo; D: Padrão de peso molecular (Ladder 100 pb, LGC biotecnologia $\AA$ ).

Figura 4 - Eletroforese dos produtos de PCR correspondentes ao gene da polimerase do TAstV-2. Coluna A: Padrão de peso molecular (Ladder 100 pb, LGC biotecnologia®); B: Controle positivo; C: Amostra de campo; D: Controle negativo.

Figura 5 - Eletroforese dos produtos de PCR correspondentes ao gene da polimerase do ANV. Coluna A: Padrão de peso molecular (Ladder 100 pb, LGC biotecnologia $\AA^{8}$ ); B: Amostra de campo; C: Controle positivo; D: Controle negativo.

Figura 6 - Eletroforese dos produtos de PCR correspondentes à região 3' UTR do TCoV. Coluna A: Amostra de campo; B: Controle positivo; C: Controle negativo; D: Padrão de peso molecular (Ladder 100 pb, LGC biotecnologia $\AA^{\circledR}$ ).

Figura 7 - Eletroforese dos produtos de PCR correspondentes ao gene S4 do Reovírus. Coluna A: Amostra de campo; B: Controle positivo; C: Controle negativo; D: Padrão de peso molecular (Ladder 100 pb, LGC biotecnologia ${ }^{\circledR}$ ).

Figura 8 - Eletroforese dos produtos de PCR correspondentes ao gene NSP4 do Rotavírus. Coluna A: Amostra de campo; B: Controle positivo; C: Controle negativo; D: Padrão de peso molecular (Ladder 100 pb, LGC biotecnologia $\AA$ ).

Figura 9 - Distribuição da produção brasileira de perus comerciais (\% de cabeças de perus por Estado produtor). Fonte: UBA, relatório anual 2009.

Figura 10 - Procedência das amostras de intestinos de perus enviadas ao laboratório de Ornitopatologia (USP). 


\section{LISTA DE GRÁFICOS}

Gráfico 1 - Percentual de positividade na detecção de vírus entéricos. 59

Gráfico 2 - Percentual de positividade de cada agente nas amostras analisadas

Gráfico 3 - Frequência de detecção de um ou mais vírus nas amostras estudadas $(n=76)$

Gráfico 4 - Distribuição das amostras quanto à positividade para um ou mais vírus, pela procedência da amostra.

Gráfico 5 - Boxplot da distribuição do número de vírus detectados por amostra, conforme a idade dos lotes em semanas. .......................... 70

Gráfico 6 - Percentual de detecção dos vírus estudados com relação à idade dos lotes........................................................................... 70

Gráfico 7 - Percentual da detecção dos vírus estudados com relação à presença de sinais clínicos nos lotes.

Gráfico 8 - Frequência do tipo de sinal clínico relatado e o número de vírus detectados por amostra. 


\section{LISTA DE QUADROS}

Quadro 1 - Detalhamento de amostras diferentes coletadas dentro do mesmo lote, no mesmo momento e daquelas com intervalo de uma (01) semana entre as coletas.

Quadro 2 - Sequência dos primers utilizados na amplificação de cada vírus, gene estudado e tamanho do fragmento amplificado. 48 


\section{LISTA DE TABELAS}

Tabela 1 - Distribuição das amostras de intestinos recebidas no laboratório de Ornitopatologia da Universidade de São Paulo, conforme o ano de coleta.

Tabela 2 - Condições de amplificação do Adenovírus aviário grupo 1 (TAV)

Tabela 3 - Condições de amplificação do Adenovirus aviário grupo 2 (HEV).

Tabela 4 - Condições de amplificação do TAstV-1 e ANV.

Tabela 5 - Condições de amplificação do TAstV-2 _..............................................4 44

Tabela 6 - Condições de amplificação do TCoV. ................................................. 45

Tabela 7 - Condições de amplificação do Reovirus................................................46

Tabela 8 - Condições de amplificação do Rotavírus. ............................................4 47

Tabela 9 - Distribuição da frequência (total e relativa) dos vírus detectados individualmente ou em associação na amostra.

Tabela 10 -Distribuição da frequência dos vírus detectados individualmente e as diferentes associações encontradas nas amostras estudadas, com relação à localidade e idade do lote.

Tabela 11 -Distribuição da frequência do número de vírus detectados em associação pela localidade (Estado) de procedência das amostras.

Tabela 12 -Distribuição das amostras positivas e negativas para vírus entéricos com relação ao Estado de origem das mesmas e estação do ano em que foi realizada a coleta.

Tabela 13 -Distribuição da frequência dos sinais clínicos relatados e número de vírus detectados nas amostras com relação à idade do lote.

Tabela 14 -Distribuição da frequência dos vírus detectados nas amostras e sinais clínicos relatados com relação à idade do lote.

Tabela 15 -Análise estatística da média do número de vírus detectados por amostra, pela idade das aves.

Tabela 16 -Distribuição da freqüência de detecção viral pela presença de sinais clínicos nos lotes.

Tabela 17 -Distribuição da frequência da detecção dos vírus estudados pela presença de sinais clínicos nos lotes. 
Tabela 18 -Relação entre os sinais clínicos relatados e o número de amostra com um ou mais vírus detectado........................................... 74 


\section{LISTA DE SIGLAS E ABREVIAÇÕES}

\begin{tabular}{|c|c|}
\hline ANV & vírus da nefrite aviária \\
\hline cDNA & ácido desoxirribonucleico complementar \\
\hline DNA & ácido desoxirribonucleico \\
\hline ELISA & ensaio imuno enzimático \\
\hline et al. & e colaboradores \\
\hline$g$ & grama \\
\hline HEV & enterite hemorrágica dos perus (grupo 2) \\
\hline IEM & immuno-microscopia eletrônica \\
\hline M & molar \\
\hline $\mathrm{ME}$ & microscopia eletrônica \\
\hline $\min$ & minutos \\
\hline $\mathrm{mL}$ & mililitro \\
\hline PAGE & eletroforese em gel de poliacrilamida \\
\hline $\mathrm{pb}$ & pares de bases \\
\hline PCR & reação em cadeia pela polimerase \\
\hline $\mathrm{pH}$ & potencial hidrogeniônico \\
\hline RNA & ácido ribonucleico \\
\hline rpm & rotações por minuto \\
\hline $\mathrm{RT}$ & transcrição reversa \\
\hline s & segundos \\
\hline TAstV-1 & astrovirus de perus tipo 1 \\
\hline TAstV-2 & astrovirus de perus tipo 2 \\
\hline TAV & adenovirus de perus (grupo 1) \\
\hline TCoV & coronavirus de perus \\
\hline TE & tampão Tris-EDTA \\
\hline$U$ & unidade \\
\hline$\mu \mathrm{L}$ & microlitro \\
\hline$\mu \mathrm{m}$ & micrômetro \\
\hline$X$ & vezes \\
\hline
\end{tabular}




\section{LISTA DE SÍMBOLOS}

$\begin{array}{ll}\stackrel{\circ}{C} & \text { graus Celsius } \\ { }_{\circledast} & \text { marca registrada } \\ \% & \text { porcentagem } \\ - & \text { negativo }\end{array}$




\section{SUMÁRIO}

INTRODUÇÃO. 20

FICHAS CLÍNICAS. .36

Sinais clínicos .36

3.2.4 Organização das amostras conforme a idade do lote 37

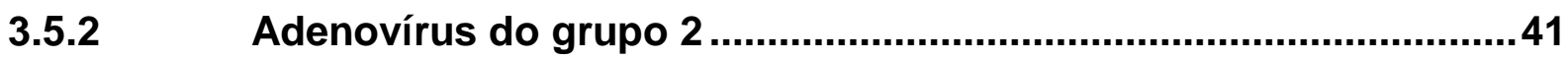

3.5.3 Astrovírus (TAstV-1, TAstV-2 e ANV) …..................................... 42

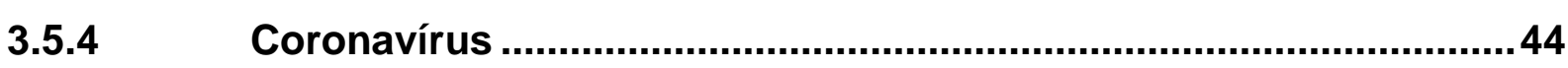

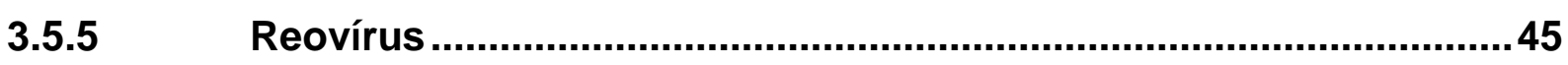

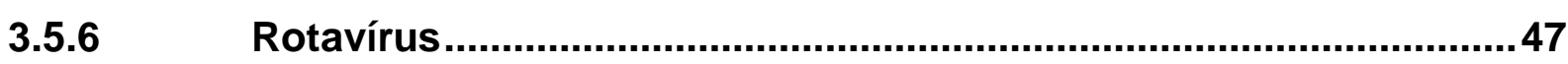




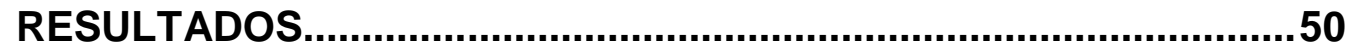

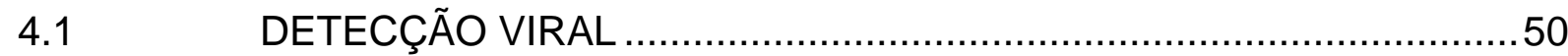

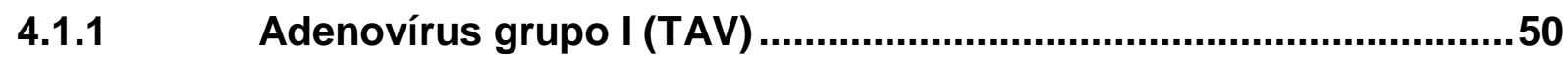

4.1.2 Adenovírus grupo II (HEV) .....................................................51

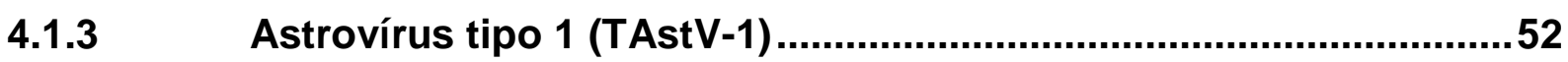

Astrovírus tipo 2 (TAstV-2) .................................................... 53

4.1.5 Vírus da nefrite aviária (ANV) ................................................ 54

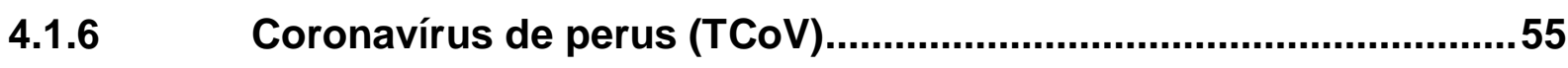

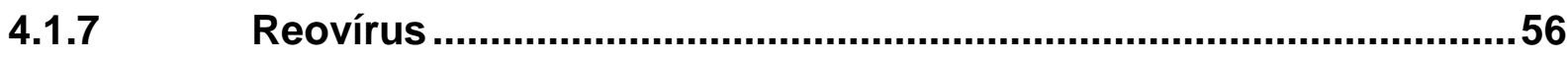

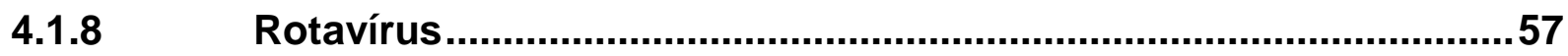

F.2 FREQUENCIA DE DETECTAÇÃO VIRAL $\ldots \ldots \ldots \ldots \ldots \ldots \ldots \ldots \ldots \ldots \ldots . \ldots \ldots$

DISTRIBUIÇÃO GEOGRÁFICA DAS AMOSTRAS $\ldots \ldots \ldots \ldots \ldots \ldots \ldots \ldots . \ldots . \ldots \ldots$

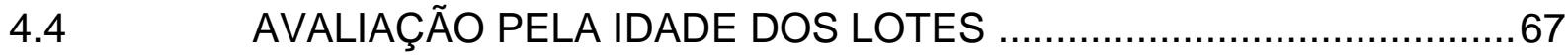

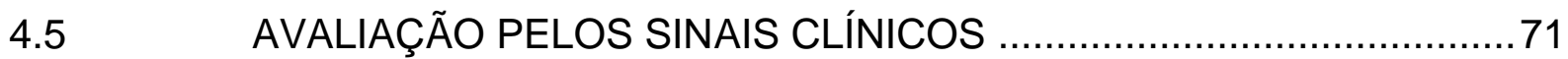

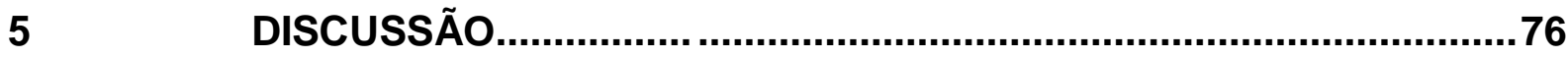

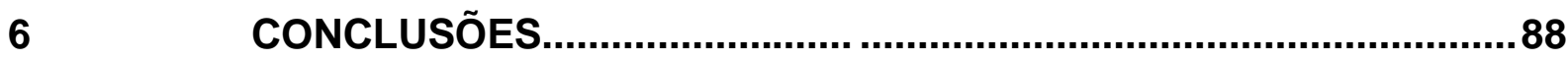

REFERÊNCIAS.........................................................................89

APÊNDICES............................................................................ 108 


\section{INTRODUÇÃO}

A avicultura brasileira tem grande destaque mundial. Segundo o Relatório Anual da União Brasileira de Avicultura (2009) a produção de carne de frango é a terceira maior do mundo, ficando atrás de Estados Unidos e China, com produção anual em 2009 de 10,090 milhões de toneladas (15,3\% da produção mundial), e o quarto maior consumidor desta carne $(11 \%$ do total mundial), atrás de Estados Unidos, China e União Europeia. O Brasil é também o terceiro maior produtor e consumidor de carne de peru (atrás dos Estados Unidos e União Europeia), e em 2009, sua produção de 466,29 mil toneladas, foi consumida em sua maioria no mercado interno, ou seja, 302,71 mil toneladas, o equivalente a $65 \%$, semelhante ao cenário encontrado no mercado de carne de frango (UNITED STATES DEPARTAMENT OF AGRICULTURE, 2010).

As aves são criadas em sistema intensivo de produção, onde pode haver fácil disseminação de um agente infeccioso para todo o lote, portanto, para permitir um contínuo crescimento do setor, são priorizadas técnicas preventivas para o controle de enfermidades nos lotes.

Dentre as doenças infecciosas que afetam as aves, aquelas que afetam o trato digestório de aves comerciais são importantes tanto em função das perdas econômicas que podem causar quanto pelo comprometimento de outros sistemas levando à diminuição da produtividade.

Uma grande variedade de agentes pode afetar o trato gastrointestinal das aves, como vírus, bactérias e parasitas. Sabe-se que os parasitas e bactérias, especialmente, Eimeria sp., Clostridium perfringens e Salmonella spp., estão comumente associados as enterites, causando sérios prejuízos a performance dos lotes. No entanto, pouco se conhece sobre a participação dos vírus entéricos, como: adenovírus, astrovírus, coronavírus, reovírus e rotavírus. Somente na ultima década a literatura tem apontado a importância destes agentes nos quadros que envolvem problemas entéricos (KOCl; SEAL; SCHULTZ-CHERRY, 2000a; YU et al., 2000; CARVER et al., 2001; VILLARREAL et al., 2006; PANTIN-JACKWOOD et al., 2007).

No Brasil, há uma grande lacuna no conhecimento sobre a ocorrência destes vírus assim como a sua associação com distúrbios entéricos em aves de produção, como frangos e perus. O diagnóstico destes agentes infecciosos é fundamental para 
a elaboração de medidas sanitárias que permitam a melhora dos plantéis avícolas brasileiros, tornando-os mais competitivos à exportação.

Este projeto teve como objetivo detectar os vírus entéricos: adenovírus, astrovírus, coronavírus, reovírus e rotavírus, a partir de material remetido por empresas avícolas ao laboratório, e associá-los a problemas entéricos em lotes de perus comerciais com relação à distribuição geográfica das amostras, idade dos lotes e presença de sinais clínicos nas aves. A detecção destes agentes foi realizada através de protocolos de reação em cadeia da polimerase previamente publicados.

O diagnóstico diferencial entre estes vírus através da utilização de métodos moleculares oferece diversas vantagens em relação aos métodos tradicionais, como: maior sensibilidade e especificidade, detecção de múltiplos agentes virais a partir de uma única amostra, ausência da necessidade de replicação viral, possibilidade de testar um grande número de amostras rapidamente e menor custo por amostra processada (PANTIN-JACKWOOD et al., 2008). 


\section{REVISÃO DE LITERATURA}

\subsection{ENTERITES VIRAIS EM PERUS}

As infecções entéricas, juntamente com as respiratórias, são as que mais contribuem para a redução no desempenho da ave e rendimento da carcaça, o que reflete em implicações econômicas no lote (TAMEHIRO; ALFIERI; ALFIERI, 2009). As doenças do trato digestório afetam o valor do lote pela redução no ganho de peso, utilização ineficiente do alimento, redução na uniformidade do lote, aumento da susceptibilidade a outras doenças e aumento dos custos com medicação (BARNES, 1997).

Nos primeiros relatos de enterites em perus, Pomeroy e Fenstermacher (1937) descreveram os sinais clínicos de uma enterite hemorrágica, e mais tarde, Peterson e Hymas (1951) relataram uma afecção entérica das aves com elevada mortalidade, intitulada de doença de Bluecomb. Diversos estudos foram realizados reproduzindo experimentalmente os sinais clínicos dessas enfermidades através da inoculação de suspensões filtradas de material fecal proveniente de aves doentes (POMEROY; SIEBURTH, 1953; SIEBURTH; JOHNSON, 1957; GROSS; MOORE, 1967).

A primeira visualização de um vírus como possível agente causal ocorreu em 1969 por Fujisaki, Kawamura e Anderson através de microscopia eletrônica (ME), onde observaram Reovírus nas fezes de perus afetados pela doença de Bluecomb. A partir de então, Adenovírus, Astrovírus, Coronavírus, Picornavírus e Rotavírus, puderam ser observados nas fezes de perus apresentando sinais entéricos utilizando-se ME (PANIGRAPHY; NAQI; HALL, 1973; CARLSON et al., 1974; TOLIN; DOMERMUTH, 1975; BERGELAND; MCADARAGH; STOTZ, 1977; IMADA; YAMAGUCHI; KAWAMURA, 1979; MCNULTY; CURRAN; MCFERRAN , 1980).

Uma grande variedade de outros agentes pode afetar o trato gastrointestinal das aves, como bactérias e parasitas. Dentre os patógenos entéricos, as bactérias que habitam em grande escala o trato gastrointestinal das aves são: Escherichia coli, Salmonella spp, Clostridium perfringens, Campylobacter sp, Listeria monocytogenes, Arcobacter sp, Serpulina sp e outras (PORTER, 1998). No entanto, 
na tentativa de se identificar um agente, diversos autores não puderam verificar a presença de bactérias nas aves acometidas por enterites, e ainda a doença pôde ser reproduzida pela inoculação de suspensões filtradas a $0,22 \mu \mathrm{m}$ e adicionadas de antibióticos, então denominadas de suspensões livres de bactérias (SIEBURTH; JOHNSON, 1957; DESHMUKH et al., 1969; HOFSTAD; ADAMS; FREY, 1969; ADAMS; HOFSTAD, 1971).

Os vírus podem induzir alteração da mucosa intestinal tornando esta uma porta de entrada para patógenos potenciais (GUY, 1998), já que tem como alvo as células epiteliais, com exceção do vírus da Enterite Hemorrágica que tem como alvo linfócitos B e macrófagos da lâmina própria (SURESH; SHARMA, 1996). Experimentos demonstraram que perus afetados com a doença de Bluecomb tiveram redução na motilidade gastrointestinal quando comparados a aves normais, e o alimento não pôde ser utilizado de forma eficiente devido à destruição dos enterócitos e vilosidades intestinais, induzindo a uma redução na absorção de glicose, íons e água. (DUKE; DZIUK; EVANSON, 1969; DZIUK; EVANSON; LARSEN, 1969).

De acordo com Guy (1998) estas alterações podem induzir deficiências nutricionais, especialmente aquelas relacionadas à absorção de vitaminas lipossolúveis e minerais. Estas deficiências podem causar alterações na ontogenia e formação de órgãos linfoides, particularmente na Bursa de Fabricius e timo, e os danos podem resultar em deficiências imunológicas e aumento da susceptibilidade a outras doenças infecciosas. O autor relata ainda que osteoporose e outras anormalidades esqueléticas eram frequentemente encontradas em frangos apresentando enfermidades gastrointestinais.

Além disso, após a eclosão, o sistema digestório dos perus é ainda imaturo (MORAN, 1985), e com limitada capacidade de absorção de carboidratos, lipídeos e proteínas (MORAN, 1985; PHELPS; EDENS; GILDERSLEEVE, 1987), sendo que nesse momento da vida as aves são vulneráveis à ação de vários agentes infecciosos e não infecciosos que as desafiam.

Dentre os vírus associados a doenças entéricas em perus podemos destacar Adenovírus, Astrovírus, Coronavírus, Reovírus, Rotavírus que podem ocorrer isoladamente ou em associação no organismo da ave (REYNOLDS; SAIF; THEIL, 1987a; SELLERS et al., 2004; DAY; SPACKMAN; PANTIN-JACKWOOD, 2007; PANTIN-JACKWOOD et al., 2008; JINDAL et al., 2010a). Os sinais clínicos e as 
lesões induzidas pelos diferentes vírus são similares, por tal motivo é difícil diagnosticar uma doença entérica e associá-la a um agente específico sem o apoio de técnicas moleculares para se determinar a presença deste agente. Além disso, a presença de mais de um vírus no trato intestinal das aves pode estar relacionada à manifestação de diferentes formas clínicas (SAIF, 2008).

Dentre as enfermidades e complexos entéricos, a Síndrome de Mortalidade Entérica das Aves (PEMS) é de grande destaque na criação de perus, pois é responsável por aumentar os índices de mortalidade nos plantéis (YU et al., 2000; CARVER et al., 2001). É considerada uma enfermidade multifatorial podendo estar associada a vírus e bactérias enteropatogênicos, sendo que a maioria dos estudos têm focado nos Astrovírus de perus (TAstV), Coronavírus de perus (TCoV) e Escherichia coli, no entanto outros agentes enterotrópicos com distribuição mundial podem estar associados à PEMS, causando grandes perdas econômicas a indústria avícola, como o Adenovírus, Reovírus, Rotavírus e Salmonella spp (BARNES; GUY, 2003).

Outra síndrome que acomete essas aves é conhecida como síndrome da enterite dos perus (PES), que diferentemente da PEMS não causa aumento de mortalidade, mas pode desencadear grandes perdas econômicas nas aves, como relatado por Jindal et al. (2009) levando uma redução de $31,8 \%$ no crescimento de aves acometidas.

Com o aprimoramento de técnicas de diagnóstico, diversas pesquisas foram conduzidas nas duas últimas décadas com o intuito de se detectar os agentes virais envolvidos nessas enterites. A técnica de Reação em Cadeia da Polimerase (PCR) permitiu vários estudos com o objetivo de se observar a prevalência desses agentes em lotes de perus. Algumas pesquisas epidemiológicas trouxeram informações importantes relacionadas à prevalência e distribuição desses vírus (VILLARREAL et al., 2006; PANTIN-JACKWOOD et al., 2007; JINDAL et al., 2008; PANTINJACKWOOD; SPACKMAN; DAY, 2008; JINDAL et al., 2010a). No entanto, no Brasil poucos estudos que abordam este tema foram publicados até o momento, sobretudo quando são consideradas doenças de etiologia viral. 


\subsection{ADENOVÍRUS}

Os adenovírus são vírus não envelopados, icosaédricos, com um diâmetro de 70 a 90 nm, seu genoma é composto por um DNA de dupla fita que possui de 26 a 45 Kb e sua replicação ocorre no núcleo (WIGAND et al., 1982; DAVISON; BENKO; HARRACH, 2003).

A família Adenoviridae é dividida em quatro gêneros: Mastadenovirus que compreende os adenovírus dos mamíferos; Aviadenovirus (antes denominado de adenovírus aviário grupo 1) que afetam aves; Siadenovirus (antes denominado adenovírus aviário grupo 2) do qual fazem parte os vírus causadores da enterite hemorrágica dos perus, da síndrome do baço marmóreo dos faisões e da esplenomegalia das galinhas; Atadenovirus (antes denominado adenovírus aviário grupo 3) que inclui o vírus da síndrome da queda de postura que afeta galinhas. Esta divisão é devido a grande diferença genotípica e fenotípica dos adenovírus (MCFERRAN, 1997; GUY, 1998; DAVISON; BENKO; HARRACH, 2003; ALVARADO et al., 2007).

Hexon é a principal proteína do capsídeo dos adenovírus e a sequência de nucleotídeos do gene hexon é importante na classificação em tipo e grupo dos adenovírus (PITCOVSKI et al., 1998). O gene hexon possui uma região conservada (não estrutural) e uma região variável (estrutural), sendo que através da região conservada é possível se fazer uma triagem, distinguindo os adenovírus dos demais vírus entéricos (HESS; RAUE; HAFEZ, 1999; MEULEMANS et al., 2001).

O vírus do gênero Aviadenovirus foi isolado no trato respiratório (SCOTT; MCFERRAN, 1972; BLALOCK et al., 1975; SIMMONS et al., 1976; SUTJIPTO et al., 1977), gastrointestinal e urinário (SCOTT; MCFERRAN, 1972) de perus apresentando redução no crescimento, conjuntivite, nefrite e aerossaculite, mas também foi encontrado em aves normais (SCOTT; MCFERRAN, 1972; CHO, 1976). $O$ agente foi detectado ainda no baço e intestinos de perus com quatro semanas de idade em lotes apresentando elevada mortalidade, através de ME (SHIVAPRASAD; WOOLCOCK; MCFARLAND, 2001).

O papel exato destes vírus no desenvolvimento de doenças nas aves ainda é desconhecido dificultando a definição das perdas econômicas relativas à sua presença (ADAIR; FITZGERALD, 2008). Em perus a presença de inclusões 
hepáticas foi relacionada a quadros de hepatite (SHIVAPRASAD; WOOLCOCK; MCFARLAND, 2001), enquanto que em frangos parece agir como um agente secundário em casos de anemia infecciosa das galinhas e doença infecciosa da Bursa (ADAIR; FITZGERALD, 2008).

O gênero Siadenovirus causa uma enterite hemorrágica aguda em perus de quatro ou mais semanas de idade que desenvolvem depressão, sangramento e morte (PIERSON; FITZGERALD, 2008). A enfermidade foi relatada em perus pela primeira vez em 1937 por Pomeroy e Fenstermacher, mas somente mais tarde adenovírus puderam ser visualizados por ME no intestino e baço de aves afetadas (CARLSON et al., 1974; TOLIN; DOMERMUTH, 1975).

O curso da doença é de 7 a 10 dias, e por se tratar de um vírus que pode levar a uma imunossupressão pode ocorrer o desenvolvimento de infecção secundária, estendendo a doença por até três semanas (PIERSON; FITZGERALD, 2008). O vírus se replica principalmente no baço e tonsilas cecais (lâmina própria) sendo capaz de causar imunossupressão nas aves afetadas devido a uma destruição dos linfócitos B e macrófagos (SURESH; SHARMA, 1996).

Testes de neutralização do vírus foram utilizados inicialmente por Domermuth e Gross (1975) para a prevenção e redução dos sinais clínicos em casos de enterite hemorrágica (HE) e para o estudo e detecção de diferentes sorotipos de adenovírus de perus do grupo 1 (SCOTT; MCFERRAN, 1972; MCFERRAN; ADAIR; CONNOR, 1975). Testes de precipitação como a difusão em gel de agar e microimmunodifusão foram utilizados para a detecção de anticorpos específicos contra HEV no baço de perus por Domermuth et al. (1972) e Domermuth, Gross e DuBose (1973), respectivamente.

Somente na década de 80 o ensaio imunoenzimático (ELISA) foi desenvolvido para a detecção de anticorpos contra adenovírus do grupo 1 em frangos (DAWSON et al., 1980) e contra HEV dos perus (SILIM; THORSEN, 1981).

Os adenovírus do grupo 1 de perus puderam ser isolados em culturas de células de rins de perus por Scott e McFerran (1972). Mais tarde, Cowen (1988) propagou adenovírus de frangos em embriões de galinhas demonstrando a via de inoculação do saco da gema como uma alternativa para a propagação de qualquer adenovírus do grupo 1, inclusive os de perus.

Em 1977, foi desenvolvida uma vacina viva avirulenta contra o vírus da enterite hemorrágica (HEV) utilizando-se o vírus da doença do baço marmóreo dos 
faisões (DOMERMUTH et al., 1977), que é inofensivo aos perus, mas que havia mostrado proteção cruzada com o HEV (DOMERMUTH et al., 1975). Mais tarde o vírus passou a ser propagado em culturas de células de leucócitos de perus que foram usadas para a produção de uma vacina atenuada, que demonstrou proteção contra estirpes virulentas do HEV (VAN DEN HURK, 1990). Em 1994, Sharma desenvolveu uma vacina contra a doença, propagando o vírus em células linfoides da doença de Marek (MDTC-RP19) que não demonstrou esplenomegalia nas aves vacinadas.

O desenvolvimento de técnicas moleculares permitiu tanto a sua utilização como ferramenta diagnóstica para a detecção rápida do agente nas aves, contribuindo para os estudos epidemiológicos (HESS; RAUE; HAFEZ, 1999; XIE et al., 1999) como para os estudos em relação à patogênese do vírus, utilizando-se técnicas de hibridização in situ e PCR (SURESH; SHARMA, 1996).

\subsection{ASTROVÍRUS}

Astrovírus são vírus pequenos, arredondados e não envelopados com diâmetro de 28 a 30nm, sendo seu genoma composto de RNA de fita simples de 6,4 a 7,3 Kb (MÉNDEZ; ARIAS, 2007). O nome é originário do grego "astron" que significa estrela, já que ao microscópio eletrônico na superfície do vírus projetam-se 5 a 6 pontas que the conferem o aspecto descrito (MADELEY; COSGROVE, 1975).

A família Astroviridae é dividida em dois gêneros: Mamastrovirus que afeta mamíferos; e Avastrovirus, que afeta aves, sendo que em perus são reconhecidos dois sorotipos (THE UNIVERSAL VIRUS DATABASE OF THE INTERNATIONAL COMMITTEE ON TAXONOMY OF VIRUSES, 2004). Já em 2005, Tang, Murgia e Saif detectaram através de analise filogenética astrovírus de perus (TAstV) e sugeriram a classificação um novo tipo, TAstV-3.

O genoma do vírus é organizado em três open reading frames que codificam proteínas não estruturais (ORF1a e ORF1b) e estruturais (ORF2) (MÉNDEZ; ARIAS, 2007). ORF1b codifica a tradução da proteína viral polimerase que é considerada altamente conservada dentro dos sorotipos, assim, primers específicos para a 
polimerase viral é capaz de detectar os diferentes sorotipos (KOCl; SEAL; SCHULTZ-CHERRY, 2000a).

Astrovírus foram observados pela primeira vez no intestino de perus jovens apresentando diarreia e mortalidade em 1980, através de microscopia eletrônica por McNulty, Curran e McFerran. Aves infectadas desenvolveram sinais clínicos com maior frequência entre a primeira e terceira semana de vida que persistiram por $10 \mathrm{a}$ 14 dias, estes incluem diarreia, emagrecimento, apatia, ingestão da cama, distúrbios de comportamento e baixa mortalidade (REYNOLDS; SAIF, 1986). Em 1990, imuno microscopia eletrônica (IEM) foi utilizada por Saif et al. para a detecção de anticorpos específicos contra astrovírus em perus apresentando sinais de enterite e diarreia.

Astrovírus foram propagados ovos embrionados de perus por Koci, Seal e Schultz-Cherry (2000b), mas não pôde ser propagado em culturas de células até o momento apesar das tentativas iniciais realizadas por McNulty, Curran e McFerran (1980).

Thouvenelle, Haynes e Reynolds (1995) detectaram que o vírus se replica e causa lesões em todo o intestino delgado, levando a um aumento na profundidade e área das criptas intestinais. Thouvenelle et al. (1995) observaram ainda que, um declínio significativo da atividade específica da maltase intestinal, apesar de passageiro, era capaz de promover má-digestão de dissacarídeos, resultando em diarreia osmótica em perus inoculados com Astrovírus. Em 2003, Koci et al. observaram que durante a infecção por Astrovírus ocorria um aumento na atividade do fator de transformação do crescimento (TGF- $\beta$ ) e sugeriram uma relação com a manutenção da integridade intestinal observada durante a infecção.

Em 1984, agentes similares ao picornavírus foram detectados em perus apresentando sinais respiratórios e entéricos (ANDRAL; TOQUIN, 1984), uma vez que esses "picornavírus" já haviam sido relatados anteriormente em frangos, passaram a ser denominados de vírus da nefrite aviária (ANV) por Imada, Yamaguchi e Kawamura (1979). Mais tarde, Connor et al. (1987) e Nicholas, Goddard e Luff. (1988) demonstraram a presença de anticorpos específicos contra o ANV em criações de perus comerciais utilizando testes de imunofluorescência. $E$, somente em 2000, esses agentes foram classificados como pertencentes à família Astroviridae através de sequenciamento do seu genoma completo, demonstrando similaridade com os astrovírus de perus (IMADA et al., 2000). 
Em geral, astrovírus de perus e ANV vêm sendo detectados no intestino de perus acometidos por enterites ao longo dos anos através de ME (REYNOLDS; SAIF; THEIL, 1987a) e RT-PCR (KOCI; SEAL; SCHULTZ-CHERRY, 2000a; VILLARREAL et al., 2006; PANTIN-JACKWOOD et al., 2007; JINDAL et al., 2008; SILVA et al., 2008). Sendo que a maioria desses autores relata a associação de astrovírus com outros agentes entéricos, como coronavírus de perus, rotavírus e reovírus.

\subsection{CORONAVÍRUS}

O coronavirus é um vírus envelopado com tamanho entre 50 e 160 nm (RITCHIE et al., 1973; SPAAN et al., 2005), com projeções em sua superfície que conferem um aspecto de coroa (NAGARAJA; POMEROY, 1997). Seu genoma é composto por uma fita simples de RNA com tamanho de 27 a $32 \mathrm{~Kb}$, sendo o maior entre os vírus RNA não segmentados (HOLMES; LAI, 1996; SPAAN et al., 2005).

O vírus pertence à família Coronaviridae, da ordem Nidovirales e o gênero Coronavirus é dividido em três grupos (1, 2 e 3), de acordo com a semelhança antigênica, sendo que o coronavírus de perus (TCoV) se insere no grupo 3, junto ao vírus da Bronquite Infecciosa das Galinhas (GUY, 2000; GOMMA et al., 2008).

Os coronavírus do grupo 3 possuem três proteínas de membrana conhecidas como: Spike glycoprotein (S); Membrane protein (M); Small envelope protein (E) e ainda a proteína do nucleocapsideo $(\mathrm{N})$. Nos terminais 5' e 3'do genoma viral existem regiões não traduzidas (UTR), e entre elas há cerca de 6 a 14 ORFs (SPAAN et al., 2005). Pela presença de regiões bem conservadas entre diferentes isolados de coronavírus de faisões, perus e vírus da bronquite infecciosa, as UTR são utilizadas para a detecção desse agente nas aves (CAVANAGH et al., 2002).

Os primeiros sinais, descritos em 1951, de uma enfermidade entérica foram enterite catarral, perda de peso e baixa mortalidade, então denominada de doença de Bluecomb em perus (PETERSON; HYMAS, 1951). Durante os anos que se seguiram diversos autores realizaram inoculações experimentais de filtrados intestinais para a reprodução desta enfermidade (POMEROY; SIEBURTH, 1953; SIEBURTH; JOHNSON, 1957; TRUSCOTT, 1968; DESHMUKH et al., 1969; 
HOFSTAD; ADAMS; FREY, 1969). No entanto, somente em 1973 agentes semelhantes aos coronavírus puderam ser visualizados em ME no intestino de aves inoculadas com filtrados intestinais originados de aves acometidas pela doença (PANIGRAPHY; NAQI; HALL, 1973; RITCHIE et al., 1973).

Os estudos iniciais na década de 50 puderam verificar o efeito neutralizante do soro originário de aves recuperadas da doença quando administrado a aves inoculadas com filtrados intestinais com o agente (SIEBURTH; JOHNSON, 1957; TUMLIN; POMEROY, 1958). Mas somente em 1973 iniciou-se estudos para a detecção específica de anticorpos contra TCoV através de IEM (RITCHIE et al., 1973), inibição da hemaglutinação (DEA et al., 1986), imunofluorescência direta (PATEL; DESHMUKH; POMEROY, 1975) imunofluorescência indireta (PATEL et al., 1976) e ELISA (DEA; TIJSSEN, 1989).

Embora o agente causador da doença de Bluecomb tenha sido propagado em ovos embrionados de galinhas por Sieburth e Pomeroy em 1955, somente em 1971, Adams e Hofstad puderam reproduzir a doença utilizando o agente propagado. $O$ coronavírus não pôde ser propagado com sucesso em cultura de células de rins de galinha, peru ou codorna, células intestinais embrionárias de perus e intestinais de codornas por Deshmukh, Larsen e Pomeroy (1973). Apenas em 1989, que Dea, Garzon e Tijssen conseguiram propagar o vírus em linhagem de células contínuas de adenocarcinoma retal humano adicionado de tripsina, demonstrando a manutenção do efeito citopático e a patogenicidade em perus após cinco (05) passagens em cultura celular.

Aves inoculadas com TCoV desenvolveram diarreia e depressão do crescimento dos três aos sete dias após a inoculação e os intestinos apresentavam distensão, conteúdo líquido e parede fina, já as aves com quatro semanas de idade apesar de positivas para TCoV sob IEM não apresentavam sinais clínicos ou lesões intestinais, demonstrando que a idade do lote é relevante para a patogenicidade do agente (ISMAIL; TANG; SAIF, 2003). Os autores demonstraram ainda que o TCoV é capaz de se replicar no intestino de frangos mas não é patogênico nessas aves.

TCOV é conhecido como um dos principais agentes envolvidos na PEMS, elevando os níveis de mortalidade nos plantéis (GUY et al., 2000; YU et al., 2000; CARVER et al., 2001). São comuns coinfecções por TAstV e TCoV em perus, sendo responsáveis por grandes perdas nas funções absortivas no intestino dessas aves e relacionadas a PEMS (BARNES; GUY, 1997; ISMAIL; TANG; SAIF, 2003). Além 
disso, esses agentes podem predispor o organismo da ave ao surgimento de infecções oportunistas por outros patógenos, como E. coli (BARNES; GUY, 1999; GUY et al., 2000; QURESHI; YU; SAIF, 2000).

Na última década o RT-PCR foi amplamente utilizado para a detecção do TCoV no intestino das aves por diversos autores tanto para fins de diagnóstico como estudos epidemiológicos (SELLERS et al., 2004; VILLARREAL et al., 2006; PANTINJACKWOOD; SPACKMAN; DAY, 2008; BUNGER et al., 2009; SILVA et al., 2009).

\subsection{REOVÍRUS}

O reovírus aviário não possui envelope e seu genoma é composto por dupla fita de RNA (dsRNA) com peso molecular aproximado de $18 \mathrm{~Kb}$ e 10 segmentos lineares de RNA (SHATKLIN; SIPE; LOH, 1968; GOUVEA; SCHNITZER, 1982a; ROSENBERG; OLSON, 1997), sendo três segmentos grande ou large na língua inglesa ( $L 1, L 2$ e L3), três médio ou medium (M1, M2 e M3) e quatro pequeno ou small (S1, S2, S3 e S4) classificados de acordo com a sua mobilidade na eletroforese em gel de poliacrilamida (PAGE).

O vírus Avian orthoreovirus, subgrupo 2, pertence ao gênero Orthoreovirus, e a família Reoviridae (KAPCZYNSKI et al., 2002; CHAPPELL et al., 2005). Há pelo menos onze sorotipos de reovírus aviário classificados através da reação de neutralização viral (KAWAMURA et al., 1965; SAHU; OLSON, 1975; WOOD et al., 1980).

O gene S4 é responsável pela codificação da proteína não estrutural $\sigma N S$, que é altamente conservada (GOUVEA; SCHNITZER, 1982b; SCHNITZER, 1985) e apresenta a menor variabilidade entre as espécies aviárias em PAGE dentre os genes S (GOUVEA; SCHNITZER, 1982b), sendo, assim, mais eficaz na detecção de amostras variantes de reovírus aviário em comparação aos testes direcionados aos genes S1 ou S3 (SPACKMAN; KAPCZYNSKI; SELLERS, 2005).

Em 1969, reovírus foram observados através de ME por Fujisaka, Kawamura e Anderson (1969) e por Deshmukh et al. (1969) no conteúdo intestinal de aves acometidas pela doença de Bluecomb. Além disso, Fujisaka, Kawamura e Anderson (1969) observaram os efeitos do agente em cultura de células de rins de galinha e 
perus, os efeitos em embriões de galinha, nos testes de neutralização viral e a presença de anticorpos no soro. Também em 1969, Deshmukh et al. e Wooley e Gratzek isolaram reovírus de lotes de perus afetados pela doença, mas na tentativa de reproduzi-la com o material isolado somente Wooley e Gratzek obtiveram sucesso.

Testes de neutralização viral foram amplamente utilizados na demonstração de diferentes sorotipos do vírus que podem afetar as aves (KAWAMURA et al., 1965; SAHU; OLSON, 1975; WOOD et al., 1980). Em seguida, PAGE foi amplamente utilizado para a detecção e estudo de reovírus por diversos autores (GOUVEA; SCHNITZER, 1982a; REYNOLDS; SAIF; THEIL, 1987a; LOZANO et al., 1992) para se observar diferenças de padrões de migração dos segmentos do RNA viral.

Em 1983, Hieronymus, Villegas e Kleven, isolaram três sorotipos diferentes do vírus em frangos acometidos pela síndrome da má-absorção, e observaram que somente um deles apresentava semelhança antigênica com o vírus vacinal S1133, demonstrando que a vacina inativa não é eficiente contra variantes do vírus.

Em infecções experimentais, reovírus promoveram aumento na motilidade intestinal, sendo que a fase aguda da infecção ocorreu entre uma e duas semanas da inoculação, e após esse período os sinais clínicos foram discretos (GOODWIN et al., 1984 a, b). Reovírus foram capazes de causar atrofia da Bursa de Fabricius e aumento do baço (MONTOGOMERY et al., 1985), linfopenia, hiperplasia de linfócitos e degeneração de células linfoides na Bursa (KERR; OLSON, 1969) . Essas alterações, apesar de transientes, mostram que o vírus é capaz de alterar estruturalmente componentes do sistema imune da ave.

Como resultado da depressão do sistema imune da ave, foi demonstrado que o reovírus aumentava a patogenicidade de outros agentes infecciosos incluindo coccídios (RUFF; ROSENBERGER, 1985), Cryptosporidium spp (GUY et al., 1987) e Escherichia coli (ROSENBERGER et al., 1986). Além disso, reovírus foram isolados de amostras de fezes de perus acometidos com PEMS, porém o papel deste agente no desenvolvimento da doença ainda não é conhecido (YU et al., 2000; HEGGENPEAY et al., 2002).

Técnicas moleculares (RT-PCR) foram utilizadas primeiramente em estudos de patogenicidade do reovírus em frangos por Liu e Giambrone (1997) aliados à hibridização in situ para a detecção do agente nos tecidos. No mesmo ano reações 
de Nested-RT-PCR e sequenciamento do vírus foram consideradas sensíveis e precisas para a detecção e diferenciação de reovírus aviários (LIU; GIAMBRONE; NIELSEN, 1997). Desde então, diversos autores vêm utilizando a técnica de RTPCR para a detecção do agente no conteúdo intestinal das aves e em estudos epidemiológicos (SPACKMAN; KAPCZYNSKI; SELLERS, 2005; PANTINJACKWOOD et al., 2007; JINDAL et al., 2008; PANTIN-JACKWOOD; SPACKMAN; DAY, 2008; JINDAL et al., 2010a).

\subsection{ROTAVÍRUS}

Rotavírus são vírus não envelopados, esféricos, com um diâmetro de aproximadamente $100 \mathrm{~nm}$ e seu genoma é composto de 11 segmentos lineares de RNA de dupla fita (MCNULTY, 1997; RAMIG et al., 2005; ESTES; KAPIKIAN, 2007).

O vírus é classificado como um gênero separado dentro da família Reoviridae e são classificados em sete grupos distintos (de $A$ até $G$ ), mas somente os grupos $A$, $D, F$ e $G$ foram descritos em plantéis de aves comerciais (ALFIERI et al., 1989; DEVITT; REYNOLDS, 1993; ITO et al., 2001; WANI et al., 2003; RAMIG et al., 2005; OTTO et al., 2006).

O gene NSP4 codifica uma proteína não estrutural e é bem conservado entre os diferentes isolados do vírus, portanto não é específico na detecção de cada grupo do vírus, não permitindo, assim, a diferenciação de cada grupo (ESTES; KAPIKIAN, 2007; PANTIN-JACKWOOD et al., 2007).

Os primeiros relatos de detecção de rotavírus nas fezes de perus jovens afetados por diarreia e aumento de mortalidade, datam de 1977 por Bergeland, McAdaragh e Stotz, e de 1978 por McNulty, Allan e Stuart, com o uso de ME. McNulty et al. (1979) propagaram o vírus em cultura de células de rins de galinha e de fígados de embriões de galinhas, e em 1992, Castro et al. propagaram o vírus em ovos embrionados de galinha de perus apresentando aumento de mortalidade, descargas hemorrágicas e retenção de gema.

PAGE foi utilizada na detecção de rotavírus em frangos (MCNULTY et al., 1981; OTTO et al., 2006) e perus (SAIF; SAIF; THEIL, 1985; REYNOLDS; SAIF; THEIL, 1987a; LOZANO et al., 1992) e de acordo com o padrão de migração do 
agente no gel de poliacrilamida foram identificados diferentes perfis eletroforéticos que definiram grupos ou tipos de vírus (KANG; NAGARAJA; NEWMAN, 1986; TODD; MCNULTY, 1986).

Yason e Schat (1986) detectaram a presença de lesões do epitélio intestinal em todos os segmentos intestinais e redução na capacidade absortiva, sugerindo que a diarreia causada pelo vírus é osmótica. Em 2006, Otto et al. demonstraram que em frangos, rotavírus poderiam induzir a uma atrofia da vilosidade intestinal, hiperplasia de criptas com presença de epitélio cuboide, demonstrando a imaturidade das células de reposição, e assim, demonstrando uma possível causa da má-absorção intestinal já relatada.

Rotavirus têm sido frequentemente encontrados nas fezes de aves acomentidas com síndromes entéricas através de RT-PCR e ainda nas fezes de aves saudáveis (MCNULTY, 2003; OTTO et al., 2006; DAY; SPACKMAN; PANTINJACKWOOD, 2007; JINDAL et al., 2008; PANTIN-JACKWOOD et al., 2008). No Brasil, foi detectado em galinhas apresentando diarreia, retardo de crescimento, e ainda em aves assintomáticas pela técnica de PAGE e isolamento em cultura celular (UILIANA et al., 2006).

O objetivo deste trabalho foi analisar a frequência dos Adenovírus (grupo 1 e 2), Astrovírus (tipo 1, 2 e ANV), Coronavírus, Reovírus e Rotavírus em amostras de fezes de perus em criações comerciais de diferentes regiões do Brasil bem como as diferentes associações de vírus que podem ser encontradas nessas amostras, e a relação com a idade das aves, presença de sinais clínicos nos lotes e distribuição geográfica das amostras. 


\section{MATERIAL E MÉTODOS}

\subsection{AMOSTRAGEM}

O conteúdo entérico de aves comerciais de estabelecimentos de produção avícola de alguns dos principais Estados brasileiros produtores de perus foram coletados de aves em granjas de produção de perus no Brasil, onde existia a ocorrência de diarreia e com comprometimento dos índices zootécnicos, nas diferentes faixas etárias de produção, e também de lotes sadios. As amostras foram coletadas por empresas de produção avícola conforme a sua disponibilidade. Foi coletado o intestino de cinco aves de cada galpão as quais foram sacrificadas na própria granja, congeladas e enviadas ao laboratório de Ornitopatologia da Universidade de São Paulo para diagnóstico. O conteúdo intestinal de cada grupo de cinco aves do mesmo galpão foi reunido e analisado como uma amostra, sendo que no total foram analisadas 76 amostras.

Após a chegada do material ao laboratório foi realizada a maceração do material para a análise ou armazenamento da amostra a $-20^{\circ} \mathrm{C}$ para posterior análise.

A constituição das amostras conforme o ano de coleta está demonstrado na tabela 1.

Tabela 1 - Distribuição das amostras de intestinos recebidas no laboratório de Ornitopatologia da Universidade de São Paulo, conforme o ano de coleta

\begin{tabular}{lc}
\hline Ano de coleta & Número de amostras $(\mathbf{n})$ \\
\hline 2004 & 17 \\
2005 & 3 \\
2006 & 2 \\
2007 & 11 \\
2008 & 7 \\
2009 & 36 \\
\hline TOTAL & 76 \\
\hline
\end{tabular}




\subsection{FICHAS CLÍNICAS}

As amostras eram, em sua maioria, acompanhadas de fichas clínicas com informações detalhadas do lote, como número de identificação, idade, localidade e sinais clínicos encontrados. No apêndice B constam as informações fornecidas nas fichas clínicas.

\subsubsection{Localidade}

As amostras foram organizadas pela origem geográfica, agrupando-as pelo Estado de procedência.

\subsubsection{Sinais clínicos}

Os sinais clínicos relatados foram organizados, para uma melhor análise dos dados, da seguinte forma:

> Sinais entéricos: presença de diarreia, fezes com muco e fezes sanguinolentas;

> Alterações zootécnicas: mortalidade, redução do ganho de peso, diminuição do consumo de ração e presença de aves refugas;

> Alterações comportamentais: apatia, agitação e prostração;

> Outras alterações: claudicação e cabeça inchada.

\subsubsection{Organização das amostras por lote}

Dentre as 76 amostras recebidas no laboratório, somente uma não continha informações sobre o lote. Houve cinco casos de coleta no mesmo lote com intervalo 
de uma (01) semana entre a primeira e a segunda coleta, totalizando dez (10) amostras, e somente um caso onde foi realizada a coleta de duas (02) amostras no mesmo galpão, em pontos diferentes do galpão, no mesmo momento (Quadro 1). 0 restante das amostras foi proveniente de lotes independentes.

\begin{tabular}{|ccccc|}
\hline Amostra & Lote & Idade & Localidade & Ano da coleta \\
\hline P2 173 B & 5603 & 6 & SC & 2004 \\
P2 173 A & 5603 & 7 & SC & 2004 \\
P4 Am.B & 1204 & 1 & SC & 2004 \\
P4 Am.D & 1204 & 2 & SC & 2004 \\
P9 16P fêmeas & 1804 & 7 & SC & 2004 \\
P10 17P fêmeas & 1804 & 8 & SC & 2004 \\
P9 16P machos & 1904 & 7 & SC & 2004 \\
P10 17P machos & 1904 & 8 & SC & 2004 \\
239-2 & 2807 & 2 & SC & 2007 \\
239-4 & 2807 & 3 & SC & 2007 \\
\hline \multicolumn{7}{c}{ Coleta de 2 amostras no mesmo lote no mesmo dia } \\
\hline 264-1 e 264-2 & 7007 & 8 & SC & 2007 \\
\hline
\end{tabular}

\subsubsection{Organização das amostras conforme a idade do lote}

As amostras foram ainda organizadas conforme a idade do lote, sendo dividas em dois grupos conforme a fase de crescimento, sendo: fase inicial (uma a quatro semanas) e fase de terminação (cinco a dezoito semanas). 


\subsection{AMOSTRAS DE REFERÊNCIA}

Para a realização da técnica de PCR, foram utilizadas como controles positivos amostras de diferentes origens:

- Adenovírus do grupo 1 (TAV): amostra de campo diagnosticada previamente no Laboratório de Ornitopatologia da Universidade de São Paulo (FMVZ-USP) como positiva para Aviadenovirus nos testes de PCR e também no sequenciamento do DNA (número de acesso do GenBank FJ360748);

- Adenovírus do grupo 2 (HEV): amostra vacinal atenuada Dindoral SPF® gentilmente cedida pela empresa Merial Saúde Animal, Brasil.

- Astrovírus do tipo 1 (TAstV-1): amostra de campo diagnosticada previamente no Laboratório de Ornitopatologia (FMVZ-USP) como positiva para TAstV-1 nos testes de RT-PCR e também no sequenciamento do DNA complementar (cDNA), número de acesso do GenBank HQ157559;

- Astrovírus do tipo 2 (TAstV-2): amostra de campo diagnosticada previamente no Laboratório de Ornitopatologia (FMVZ-USP) como positiva para TAstV-2 nos testes de RT-PCR e também no sequenciamento do cDNA (a ser publicada no GenBank);

- Vírus da nefrite aviária (ANV): amostras de campo positivas gentilmente cedidas pela Dra. Erica Spackman do Southeast Poultry Research Laboratory, USDA, Agricultural Research Service, Athens, Georgia. Remetida ao laboratório em cartões FTA $^{\circledR}$ (Whatman Itd., GE Healthcare,USA).

- Coronavírus (TCoV): amostra vacinal atenuada MASS® I SPF H120, contra a Bronquite infecciosa das galinhas, gentilmente cedida pela empresa Fort Dodge Saúde Animal, Brasil.

- Rotavírus: amostras de campo positivas gentilmente cedidas pela Dra. Erica Spackman do Southeast Poultry Research Laboratory, USDA, Agricultural Research Service, Athens, Georgia. Remetida ao laboratório em cartões FTA ${ }^{\circledR}$ (Whatman Itd., GE Healthcare,USA).

- Reovírus: vacina viva atenuada de reovírus aviário, cepa 1133, produzida em cultura de tecidos de embriões SPF, NOBILIS ${ }^{\circledR}$ REO 1133 (Laboratório Intervet Schering-Plough Animal Health, Brasil).

Em todas as reações foi utilizada água ultra pura (milliQ® - Millipore) como controle negativo. 


\subsection{EXTRAÇÃO DE DNA E RNA}

A partir do conteúdo intestinal foi feita uma suspensão na concentração de $20 \%$, ou seja, $250 \mu \mathrm{L}$ de amostra macerada para $1000 \mu \mathrm{L}$ de tampão Tris/cálcio (Tris/HCl 0,1 M; $\mathrm{CaCl}_{2} 1,5 \mathrm{mM} ; \mathrm{pH}$ 7,3). Após a diluição a amostra foi mantida em temperatura ambiente por 30 minutos com agitações manuais periódicas, em seguida, centrifugada a $5900 \times$ g por 15 minutos ou $8000 \times$ g por 10 minutos. Foram coletados $250 \mu \mathrm{L}$ do sobrenadante para a extração imediata ou foi mantido a - $20^{\circ} \mathrm{C}$ até o processamento da extração (MUNFORD, 2007).

Os reagentes necessários à extração estão descritos no apêndice $A$. A extração de RNA para a detecção do TAstV-1, TAstV-2, ANV, TCoV, Reovírus e Rotavírus foi realizada com o reagente Brazol® (LGC Biotecnologia, Brasil) de acordo com as recomendações do fabricante, a partir de $250 \mu$ l do sobrenadante da suspensão:

1) Adicionar $750 \mu \mathrm{L}$ de Brazol para $250 \mu \mathrm{L}$ de amostra (3:1) e homogeneizar;

2) Incubar por 5 minutos a temperatura ambiente 15 a $30^{\circ} \mathrm{C}$;

3) Adicionar $150 \mu \mathrm{L}$ de clorofórmio, homogeneizar (com as mãos) e incubar a temperatura ambiente por 15 minutos;

4) Centrifugar a $12000 \times \mathrm{g}$ por 15 minutos a $4^{\circ} \mathrm{C}$;

5) Transferir o sobrenadante em novos tubos (manter o precipitado a $-20^{\circ} \mathrm{C}$ para posterior extração do DNA);

6) Completar os tubos com $500 \mu \mathrm{L}$ de isopropanol;

7) Incubar a temperatura ambiente por 10 minutos;

8) Centrifugar a $12000 \times \mathrm{g}$ por 10 minutos a $4^{\circ} \mathrm{C}$;

9) Remover o sobrenadante;

10) Adicionar $750 \mu \mathrm{L}$ de etanol $75 \%$ e homogeneizar;

11) Centrifugar a $7500 \times$ g por 5 minutos a $4^{\circ} \mathrm{C}$;

12) Descartar o sobrenadante e deixar secar os tubos virados no papel por 10 minutos;

13) Dissolver o RNA em $20 \mu \mathrm{L}$ de DPEC e incubar na placa a $56^{\circ} \mathrm{C}$ por 10 minutos;

14) Armazenar a $-80^{\circ} \mathrm{C}$. 
Extração de DNA com kit Brazol® (LGC Biotecnologia, Brasil), continuação a partir da 5 fase da extração do RNA:

1) Remover a fase aquosa restante sobre a interfase e precipitar o DNA da interfase e da fase orgânica com etanol;

2) Adicionar $225 \mu \mathrm{L}$ de etanol $100 \%$ e homogeneizar por inversão (com as mãos);

3) Incubar as amostras em temperatura ambiente por 2 a 3 minutos;

4) Centrifugar no máximo $2000 \mathrm{~g}$ por 5 minutos a $4^{\circ} \mathrm{O}$;

5) Remover o sobrenadante de fenol e etanol;

6) Homogeneizar o pellet de DNA com $750 \mu \mathrm{L}$ de solução de etanol $10 \%$ contendo $0,1 \mathrm{M}$ de citrato de Sódio e deixe incubar por 30 minutos a temperatura ambiente;

7) Centrifugar a $2000 \mathrm{~g}$ por 5 minutos a $4^{\circ} \mathrm{C}$;

8) Repetir os passos 5 a 7 (uma vez) e descartar o sobrenadante;

9) Ressuspender o pellet de DNA em $1125 \mu \mathrm{L}$ de etanol $75 \%$;

10) Deixar em temperatura ambiente por 10 a 20 minutos com homogeneizações periódicas;

11) Centrifugar a $2000 \mathrm{~g}$ por 5 minutos a $4^{\circ} \mathrm{C}$;

12) Descartar o sobrenadante e deixar secar os tubos virados no papel por 10 minutos;

13) Dissolver o DNA em $30 \mu \mathrm{L}$ de $\mathrm{NaOH} 8 \mathrm{M}$ e incubar na placa a $56^{\circ} \mathrm{C}$ por $10 \mathrm{~min}$;

14) Armazenar a $-20^{\circ} \mathrm{C}$.

\subsection{TÉCNICA DA REAÇÃO EM CADEIA DA POLIMERASE (PCR)}

Para o diagnóstico molecular foi utilizada a técnica de reação em cadeia da polimerase com primer e protocolos específicos para todos os vírus estudados, conforme descrito nos itens abaixo. 


\subsubsection{Adenovírus do grupo 1}

A detecção de Adenovírus do grupo 1 (TAV) foi realizada pela prova de PCR utilizando-se primers que amplificam um fragmento do gene hexon dos adenovírus, de acordo com Alvarado et al. (2007), sem reação cruzada com os adenovírus de mamíferos (Quadro 2).

PCR: $5 \mu \mathrm{L}$ do DNA extraído foram adicionados ao mix de PCR contendo 1 x PCR Buffer (Invitrogen $\AA$ ), 0,2 mM de cada dNTP, 0,5 $\mu \mathrm{M}$ de cada primer (Hexon A e Hexon B, Quadro 2), $\mathrm{MgCl}_{2}$ 1,5 mM e 2,5U de Taq DNA polimerase (Invitrogen®) para um volume final de $50 \mu \mathrm{L}$. Para a amplificação do DNA foi utilizado o programa descrito na tabela 2.

Tabela 2 - Condições de amplificação do Adenovírus aviário grupo 1 (TAV)

\begin{tabular}{ccc}
\hline Temperatura & Tempo & Ciclos \\
\hline $94^{\circ} \mathrm{C}$ & $5 \mathrm{~min}$ & 1 ciclo (Desnaturação) \\
\hline $94^{\circ} \mathrm{C}$ & $1 \mathrm{~min}$ & \\
$52^{\circ} \mathrm{C}$ & $45 \mathrm{~s}$ & 35 ciclos (Hibridização) \\
$72^{\circ} \mathrm{C}$ & $1 \mathrm{~min} 30 \mathrm{~s}$ & \\
\hline $72^{\circ} \mathrm{C}$ & $10 \mathrm{~min}$ & 1 ciclo (Extensão final) \\
\hline \hline
\end{tabular}

Os produtos do PCR foram analisados em gel de agarose a 1,5 \% imerso em tampão Tris-Borato-EDTA (Tris-Borato 0,045 M, EDTA $1 \mathrm{mM}$ ). Foram consideradas positivas para TAV as amostras que resultaram na banda de 897 pares de base (pb) em gel de agarose a 1,5\% corado com BlueGreen® (LGC Biotecnologia) através de visualização sob transiluminação do gel em luz ultravioleta.

\subsubsection{Adenovírus do grupo 2}

A detecção de adenovírus do grupo 2 (HEV), causadores da enterite hemorrágica dos perus foi realizada pela prova de PCR utilizando-se primers 
(Quadro 2) que amplificam um fragmento do gene codificador do hexon dos adenovírus, de acordo com Hess, Raue e Hafez (1999).

PCR: $5 \mu \mathrm{L}$ do DNA extraído foram adicionados ao mix de PCR contendo 1 x PCR Buffer (Invitrogen ${ }^{\circledR}$ ), 0,2 mM de cada dNTP, 0,5 $\mu \mathrm{M}$ de cada primer (HEV1F e HEV1R, quadro 2), $\mathrm{MgCl}_{2} 2 \mathrm{mM}$ e $4 \mathrm{U}$ de Taq DNA polimerase (Invitrogen®) para um volume final de $50 \mu \mathrm{L}$. Para a amplificação do DNA foi utilizado o programa descrito na tabela 3.

Tabela 3 - Condições de amplificação do Adenovirus aviário grupo 2 (HEV)

\begin{tabular}{ccc}
\hline Temperatura & Tempo & Ciclos \\
\hline $94^{\circ} \mathrm{C}$ & $3 \mathrm{~min}$ & 1 ciclo (Desnaturação) \\
\hline $94^{\circ} \mathrm{C}$ & $1 \mathrm{~min}$ & \\
$55^{\circ} \mathrm{C}$ & $1 \mathrm{~min}$ & 40 ciclos (Hibridização) \\
$72^{\circ} \mathrm{C}$ & $1 \mathrm{~min} 30 \mathrm{~s}$ & \\
\hline $72^{\circ} \mathrm{C}$ & $10 \mathrm{~min}$ & 1 ciclo (Extensão final) \\
\hline \hline
\end{tabular}

Os produtos do PCR foram analisados em gel de agarose a 1,5\% imerso em tampão Tris-Borato-EDTA (Tris-Borato 0,045 M, EDTA $1 \mathrm{mM}$ ). Foram consideradas positivas para HEV as amostras que resultaram na banda de 1647 pb em gel de agarose a 1,5\% corado com BlueGreen® (LGC Biotecnologia) através de visualização sob transiluminação do gel em luz ultravioleta.

\subsubsection{Astrovírus (TAstV-1, TAstV-2 e ANV)}

Os Astrovírus foram detectados pela reação de transcrição reversa seguida pela PCR (RT-PCR), utilizando-se primers que amplificam um fragmento do gene da polimerase, específicos para cada tipo do vírus.

Para a detecção de Astrovírus do tipo 1 foram utilizados os primers T1polF e T1polR de acordo com Day, Spackman e Pantin-Jackwood (2007). Para a detecção de Astrovírus do tipo 2 foram utilizados os primers MKpol 10 e Mkpol 11 de acordo 
com Koci, Seal e Schultz-Cherry (2000a), e para ANV os primers ANV-F e ANV-R de acordo com Pantin-Jackwood et al. (2008). A sequencia dos primers encontra-se no quadro 2.

Síntese de DNA complementar (cDNA) através de transcrição reversa: Para os três Astrovírus estudados a reação de transcrição reversa foi a mesma. Foram desnaturados $7 \mathrm{~mL}$ do RNA extraído a $95^{\circ} \mathrm{C}$ por 5 minutos e adicionados ao mix da transcrição reversa contendo 1 x First Strand Buffer (Invitrogen®), $1 \mathrm{mM}$ de cada dNTP, DTT 10mM, $1 \mu \mathrm{M}$ de cada primer (conforme o tipo viral estudado) e $200 \mathrm{U}$ MMLV Transcriptase reversa (Invitrogen®) para uma reação final de $20 \mu \mathrm{L}$. A transcrição reversa foi realizada a $45^{\circ} \mathrm{C}$ por 60 minutos, seguidos de 10 minutos a $72^{\circ} \mathrm{C}$.

PCR para a detecção de TAstV-1 e ANV individualmente: $4 \mu \mathrm{L}$ do cDNA foram adicionados ao mix de PCR contendo 1 x PCR Buffer (Invitrogen®), 0,2 mM de cada dNTP, 0,6 $\mu \mathrm{M}$ de cada primer (T1pol 1F, T1pol 1R, ANV-F e ANV-R, conforme o vírus estudado), $\mathrm{MgCl}_{2} 2 \mathrm{mM}$ e $5 \mathrm{U}$ de Taq DNA polimerase (Invitrogen®) para um volume final de $50 \mu \mathrm{L}$. Para a amplificação do cDNA foi utilizado o programa descrito na tabela 4.

Tabela 4 - Condições de amplificação do TAstV-1 e ANV

\begin{tabular}{ccc}
\hline Temperatura & Tempo & Ciclos \\
\hline $95^{\circ} \mathrm{C}$ & $5 \mathrm{~min}$ & 1 ciclo (Desnaturação) \\
\hline $94^{\circ} \mathrm{C}$ & $30 \mathrm{~s}$ & \\
$55^{\circ} \mathrm{C}$ & $30 \mathrm{~s}$ & 35 ciclos (Hibridização) \\
$72^{\circ} \mathrm{C}$ & $1 \mathrm{~min}$ & \\
\hline $72^{\circ} \mathrm{C}$ & $10 \mathrm{~min}$ & 1 ciclo (Extensão final) \\
\hline \hline
\end{tabular}

Os produtos do PCR foram analisados em gel de agarose a 1,5 \% imerso em tampão Tris-Borato-EDTA (Tris-Borato 0,045 M, EDTA $1 \mathrm{mM}$ ). Foram consideradas positivas as amostras que resultaram na banda de 251 pb para TAstV-1 e 473 pb para ANV, em gel de agarose a 1,5\% corado com BlueGreen® (LGC Biotecnologia) através de visualização sob transiluminação do gel em luz ultravioleta. 
PCR para a detecção de TAstV-2: $4 \mu \mathrm{L}$ do cDNA foram adicionados ao mix de PCR contendo $1 \times$ PCR Buffer (Invitrogen $\AA$ ), 0,2 $\mathrm{mM}$ de cada dNTP, 0,5 $\mu \mathrm{M}$ de cada primer (Mkpol 10 e Mkpol11), $\mathrm{MgCl}_{2}, 1,5 \mathrm{mM}$ e 2,5U de Taq DNA polimerase (Invitrogen $\AA$ ) para um volume final de $50 \mu \mathrm{L}$. Para a amplificação do cDNA foi utilizado o programa descrito na tabela 5 .

Tabela 5 - Condições de amplificação do TAstV-2

\begin{tabular}{ccc}
\hline Temperatura & Tempo & Ciclos \\
\hline $94^{\circ} \mathrm{C}$ & $3 \mathrm{~min}$ & 1 ciclo (Desnaturação) \\
\hline $94^{\circ} \mathrm{C}$ & $30 \mathrm{~s}$ & \\
$56^{\circ} \mathrm{C}$ & $1 \mathrm{~min}$ & 35 ciclos (Hibridização) \\
$72^{\circ} \mathrm{C}$ & $2 \mathrm{~min}$ & \\
\hline $72^{\circ} \mathrm{C}$ & $10 \mathrm{~min}$ & 1 ciclo (Extensão final) \\
\hline \hline
\end{tabular}

Os produtos do PCR foram analisados em gel de agarose a 1,5\% imerso em tampão Tris-Borato-EDTA (Tris-Borato 0,045 M, EDTA $1 \mathrm{mM}$ ). Foram consideradas positivas para TAstV-2 as amostras que resultaram na banda de $802 \mathrm{pb}$ em gel de agarose a 1,5\% corado com BlueGreen® (LGC Biotecnologia) através de visualização sob transiluminação do gel em luz ultravioleta.

\subsubsection{Coronavírus}

Para se detectar o Coronavírus de perus (TCoV) nas amostras foi utilizada uma reação de Nested RT-PCR que amplifica um segmento da região 3'UTR (região não traduzida 3') dos coronavírus, utilizando primers específicos UTR 41, UTR 11 e UTR 31 (Quadro 2) em condições de reação descritas por Cavanagh et al. (2002).

Síntese de cDNA através de transcrição reversa: Foram desnaturados $7 \mathrm{~mL}$ do RNA extraído a $95 \stackrel{\circ}{\circ}$ por 5 minutos e adicionados ao mix da transcrição reversa contendo $1 \times$ First Strand Buffer (Invitrogen $\AA$ ), $1 \mathrm{mM}$ de cada dNTP, DTT $10 \mathrm{mM}, 1 \mu \mathrm{M}$ de cada primer (UTR 41 e UTR 11) e 200 U M-MLV Transcriptase reversa (Invitrogen $\AA$ ) 
para uma reação final de $20 \mu \mathrm{L}$. A transcrição reversa foi realizada a $45^{\circ} \mathrm{C}$ por 60 minutos, seguidos de 10 minutos a $72^{\circ} \mathrm{C}$.

PCR: $5 \mu \mathrm{L}$ do cDNA foram adicionados ao mix do PCR contendo 1 x PCR Buffer (Invitrogen $\AA$ ), 0,2 mM de cada dNTP, 0,5 $\mu \mathrm{M}$ de cada primer (UTR 41 e UTR 11), $\mathrm{MgCl}_{2}$ 1,5 mM e 2,5 U de Taq DNA polimerase (Invitrogen®) para uma reação final de $50 \mu \mathrm{L}$. Para a amplificação do cDNA foi utilizado o programa descrito na tabela 6.

Tabela 6 - Condições de amplificação do TCoV

\begin{tabular}{ccc}
\hline Temperatura & Tempo & Ciclos \\
\hline $94^{\circ} \mathrm{C}$ & $3 \mathrm{~min}$ & 1 ciclo (Desnaturação) \\
\hline $94^{\circ} \mathrm{C}$ & $1 \mathrm{~min}$ & \\
$48^{\circ} \mathrm{C}$ & $1 \operatorname{min~e~} 30 \mathrm{~s}$ & 35 ciclos (Hibridização) \\
$72^{\circ} \mathrm{C}$ & 1 min e $30 \mathrm{~s}$ & \\
\hline $72^{\circ} \mathrm{C}$ & $10 \mathrm{~min}$ & 1 ciclo (Extensão final) \\
\hline \hline
\end{tabular}

NESTED: $5 \mu \mathrm{L}$ do produto de PCR foram adicionados ao mix do nested contendo $1 \mathrm{x}$ PCR Buffer (Invitrogen®), 0,2 mM de cada dNTP, 0,5 $\mu \mathrm{M}$ de cada primer (UTR $41 \mathrm{e}$ UTR 31), $\mathrm{MgCl}_{2}$ 1,5mM e 2,5 U de Taq DNA polimerase (Invitrogen®) para uma reação final de $50 \mu \mathrm{L}$ e submetido ao mesmo ciclo de amplificação utilizado na reação de PCR.

Os produtos do PCR foram analisados em gel de agarose a 1,5 \% imerso em tampão Tris-Borato-EDTA (Tris-Borato 0,045 M, EDTA $1 \mathrm{mM}$ ). Foram consideradas positivas para TCoV as amostras que resultaram na banda de 179 pb em gel de agarose a 1,5\% corado com BlueGreen® (LGC Biotecnologia) através de visualização sob transiluminação do gel em luz ultravioleta.

\subsubsection{Reovírus}

A detecção do Reovírus nas amostras foi realizada através de uma reação de RT-PCR que amplifica um segmento de 1120 pb do gene S4, utilizando primers 
específicos Reo-F e Reo-R (Quadro 2) em condições de reação descritos por Pantin-Jackwood et al. (2008).

Síntese de cDNA através de transcrição reversa: Foram desnaturados $7 \mathrm{~mL}$ do RNA extraído a $95 \stackrel{\circ}{\circ}$ por 5 minutos e adicionados ao mix da transcrição reversa contendo $1 \mathrm{x}$ First Strand Buffer (Invitrogen®), $1 \mathrm{mM}$ de cada dNTP, DTT 10mM, $1 \mu \mathrm{M}$ de cada primer (Reo-F e Reo-R) e 200U M-MLV Transcriptase reversa (Invitrogen®) para uma reação final de $20 \mu \mathrm{L}$. A transcrição reversa foi realizada a $45^{\circ} \mathrm{C}$ por 60 minutos, seguidos de 10 minutos a $72^{\circ} \mathrm{C}$.

PCR: $4 \mu \mathrm{L}$ do cDNA foram adicionados ao mix de PCR contendo 1 x PCR Buffer (Invitrogen $\AA$ ), 0,2mM de cada dNTP, 0,6 $\mu \mathrm{M}$ de cada primer (Reo-F e Reo-R), 1 $\mathrm{MgCl}_{2}, 5 \mathrm{mM}$ e $5 \mathrm{U}$ de Taq DNA polimerase (Invitrogen®) para um volume final de 50 $\mu \mathrm{L}$. Para a amplificação do cDNA foi utilizado o programa descrito na tabela 7.

Tabela 7 - Condições de amplificação do Reovirus

\begin{tabular}{ccc}
\hline Temperatura & Tempo & Ciclos \\
\hline $95^{\circ} \mathrm{C}$ & $5 \mathrm{~min}$ & 1 ciclo (Desnaturação) \\
\hline $94^{\circ} \mathrm{C}$ & $30 \mathrm{~s}$ & \\
$58^{\circ} \mathrm{C}$ & $30 \mathrm{~s}$ & 35 ciclos (Hibridização) \\
$72^{\circ} \mathrm{C}$ & $1 \mathrm{~min}$ & \\
\hline $72^{\circ} \mathrm{C}$ & $10 \mathrm{~min}$ & 1 ciclo (Extensão final) \\
\hline \hline
\end{tabular}

Os produtos do PCR foram analisados em gel de agarose a 1,5 \% imerso em tampão Tris-Borato-EDTA (Tris-Borato 0,045 M, EDTA $1 \mathrm{mM}$ ). Foram consideradas positivas para Reovírus as amostras que resultaram na banda de 1120 pb em gel de agarose a 1,5\% corado com BlueGreen® (LGC Biotecnologia) através de visualização sob transiluminação do gel em luz ultravioleta. 


\subsubsection{Rotavírus}

A detecção do Rotavírus nas amostras foi realizada através de uma reação de RT-PCR que amplifica um segmento de 630 pb do gene NSP4, utilizando primers específicos NSP4-F e NSP4-R (Quadro 2) em condições de reação descritos por Pantin-Jackwood et al. (2008).

Síntese de cDNA através de transcrição reversa: Foram desnaturados $7 \mathrm{~mL}$ do RNA extraído a $95{ }^{\circ} \mathrm{C}$ por 5 minutos e adicionados ao mix da transcrição reversa contendo $1 \mathrm{x}$ First Strand Buffer (Invitrogen®), $1 \mathrm{mM}$ de cada dNTP, DTT $10 \mathrm{mM}, 1 \mu \mathrm{M}$ de cada primer (NSP4-F e NSP4-R) e 200U M-MLV Transcriptase reversa (Invitrogen®) para uma reação final de $20 \mu \mathrm{L}$. A transcrição reversa foi realizada a $45^{\circ} \mathrm{C}$ por 60 minutos, seguidos de 10 minutos a $72^{\circ} \mathrm{C}$.

PCR: $4 \mu \mathrm{L}$ do cDNA foram adicionados ao mix de PCR contendo 1 x PCR Buffer (Invitrogen $\AA$ ), 0,2mM de cada dNTP, 0,6 $\mu \mathrm{M}$ de cada primer (NSP4-F e NSP4-R), $\mathrm{MgCl}_{2}$ 1,5 mM e $5 \mathrm{U}$ de Taq DNA polimerase (Invitrogen®) para um volume final de $50 \mu \mathrm{L}$. Para a amplificação do cDNA foi utilizado o programa descrito na tabela 8.

Tabela 8 - Condições de amplificação do Rotavírus

\begin{tabular}{ccc}
\hline Temperatura & Tempo & Ciclos \\
\hline $95^{\circ} \mathrm{C}$ & $5 \mathrm{~min}$ & 1 ciclo (Desnaturação) \\
\hline $94^{\circ} \mathrm{C}$ & $30 \mathrm{~s}$ & \\
$58^{\circ} \mathrm{C}$ & $30 \mathrm{~s}$ & 35 ciclos (Hibridização) \\
$72^{\circ} \mathrm{C}$ & $1 \mathrm{~min}$ & \\
\hline $72^{\circ} \mathrm{C}$ & $10 \mathrm{~min}$ & 1 ciclo (Extensão final) \\
\hline \hline
\end{tabular}

Os produtos do PCR foram analisados em gel de agarose a 1,5 \% imerso em tampão Tris-Borato-EDTA (Tris-Borato 0,045 M, EDTA $1 \mathrm{mM}$ ). Foram consideradas positivas para Rotavírus as amostras que resultaram na banda de 630 pb em gel de agarose a 1,5\% corado com BlueGreen® (LGC Biotecnologia) através de visualização sob transiluminação do gel em luz ultravioleta. 


\begin{tabular}{|c|c|c|c|}
\hline Vírus estudado & $\begin{array}{c}\text { Gene } \\
\text { estudado }\end{array}$ & Sequências dos primers & $\begin{array}{c}\text { Fragmento } \\
\text { Amplificado (pb) }\end{array}$ \\
\hline $\begin{array}{c}\text { Adenovírus grupo } \\
1(\mathrm{TAV})\end{array}$ & Hexon & $\begin{array}{l}\text { Hexon A: 5'CAA RTT CAG RCA GAC } \\
\text { GGT 3' } \\
\text { Hexon B: 5'TAG TGA TGM CGS GAC } \\
\text { ATC AT 3' }\end{array}$ & 897 \\
\hline $\begin{array}{c}\text { Adenovírus grupo } \\
2(\mathrm{HEV})\end{array}$ & Hexon & $\begin{array}{l}\text { HEV1F: 5'TAC TGC TGC TAT TTG TTG } \\
\text { TG 3' } \\
\text { HEV2R: 5'TCA TTA ACT CCA GCA ATT } \\
\text { GG 3' }\end{array}$ & 1647 \\
\hline $\begin{array}{c}\text { Coronavírus } \\
\text { (TCoV) }\end{array}$ & 3، UTR & $\begin{array}{c}\text { UTR 11: } \\
\text { 5'GCTCTAACTCTATACTAGCCTA 3' } \\
\text { UTR 31: } \\
\text { 5'GGGCGTCCAAGTGCTGTACCC 3' } \\
\text { UTR 41: } \\
\text { 5'ATGTCTATCGCCAGGGAAATGTC 3' }\end{array}$ & 179 \\
\hline $\begin{array}{l}\text { Astrovírus tipo I } \\
\text { (TAstV-1) }\end{array}$ & Polimerase & $\begin{array}{l}\text { T1polf: 5'AGC TYA TGM GGT TCT TTC } \\
\text { TTC TYG 3' } \\
\text { T1polR: 5'GAT GGT GGG TAG CCT ATT } \\
\text { GTG TTC 3' }\end{array}$ & 251 \\
\hline $\begin{array}{c}\text { Astrovírus tipo II } \\
\text { (TAstV-2) }\end{array}$ & Polimerase & $\begin{array}{l}\text { MKpol10: 5'TGG CGG CGA ACT CCT } \\
\text { CAA CA 3' } \\
\text { Mkpol11: 5' AAT AAG GTC TGC ACA } \\
\text { GGT CG 3' }\end{array}$ & 802 \\
\hline Reovírus & S4 & $\begin{array}{l}\text { S4-F13: 5'GTG GGT GTT GGA GTT TCC } \\
\text { CG 3' } \\
\text { S4R1133: 5'TAC GCC ATC CTA GCT } \\
\text { GGA 3' }\end{array}$ & 1120 \\
\hline Rotavírus & NSP4 & $\begin{array}{l}\text { NSP4-F30: 5'GTG CGG AAA GAT GGA } \\
\text { GAA C 3' } \\
\text { NSP4-R660: 5'GTT GGG GTA CCA GGG } \\
\text { ATT AA 3' }\end{array}$ & 630 \\
\hline $\begin{array}{l}\text { Vírus da Nefrite } \\
\text { Aviária (ANV) }\end{array}$ & Polimerase & $\begin{array}{l}\text { ANV-F: 5'GYT GGG CGC YTC YTT YGA } \\
\text { YAC 3' } \\
\text { ANV-R: 5' CRT TTG CCC KRT ART CTT } \\
\text { TRT 3' }\end{array}$ & 473 \\
\hline
\end{tabular}

Quadro 2 - Sequência dos primers utilizados na amplificação de cada vírus, gene estudado e tamanho do fragmento amplificado 


\subsection{ANÁLISE ESTATÍSTICA DOS RESULTADOS}

Os resultados foram analisados através de estatística descritiva quanto à frequência de positividade encontrada para cada agente estudado, relacionando-se com as informações descritas nas fichas clínicas encaminhadas com as amostras. Além disso, quando aplicável foi realizada a análise de variância (ANOVA) e se significativo submetido a testes de comparação de médias (TUKEY), ao nível de significância 0,05 $(p<0,05)$.

As análises estatísticas foram realizadas utilizando o programa Minitab® 16.1.0 (versão 2010). 


\section{RESULTADOS}

Os resultados demonstram a frequência de detecção viral individual e as associações dos diferentes agentes nas amostras, bem como a relação com a distribuição geográfica, idade das aves e presença de sinais clínicos nos lotes, conforme descrito nos itens abaixo.

\subsection{DETECÇÃO VIRAL}

A visualização das amostras de PCR em gel de agarose 1,5\% para os vírus entéricos produziu fragmentos de tamanhos específicos para cada agente.

\subsubsection{Adenovírus grupo I (TAV)}

A técnica de PCR utilizada foi capaz de detectar o DNA do TAV produzindo um fragmento de 897 pb, observado após a eletroforese em gel de agarose 1,5\% (Figura 1). 


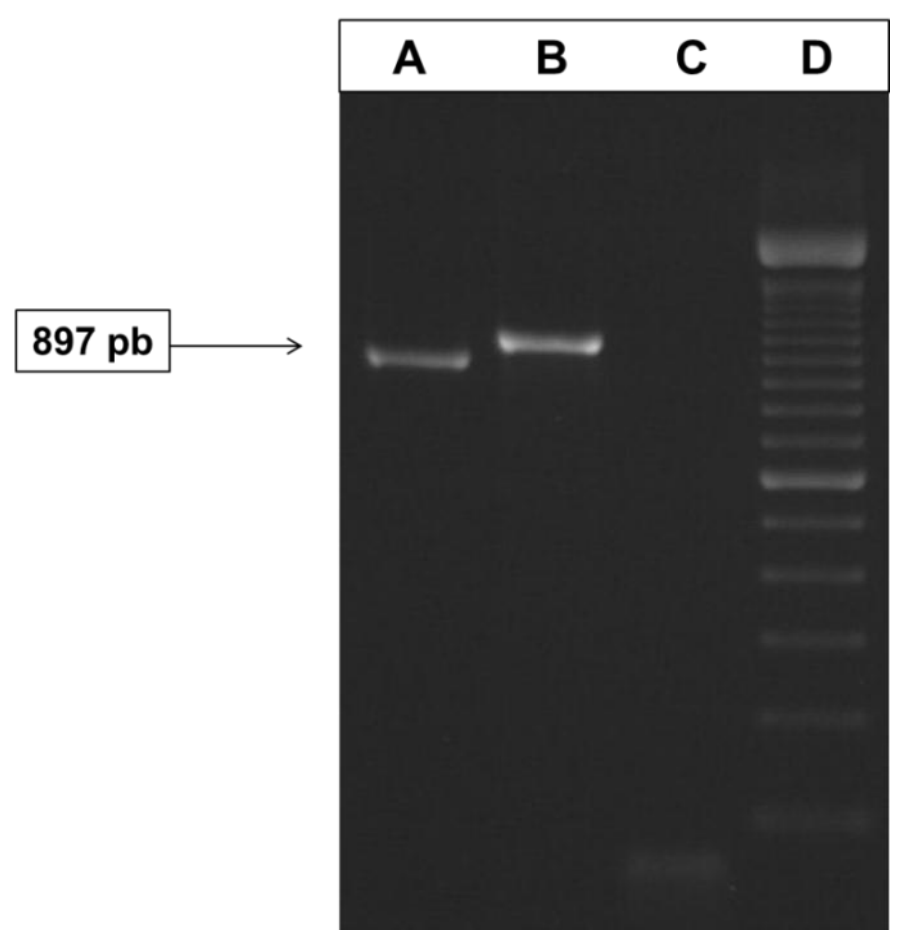

Figura 1 - Eletroforese dos produtos de PCR correspondentes ao gene hexon do TAV. Coluna A: Amostra de campo; B: Controle positivo; C: Controle negativo; D: Padrão de peso molecular (Ladder 100 pb, LGC biotecnologia $\AA^{\circledR}$ )

\subsubsection{Adenovírus grupo II (HEV)}

A técnica de PCR utilizada foi capaz de detectar o DNA do HEV produzindo um fragmento de 1647 pb, observado após a eletroforese em gel de agarose 1,5\% (Figura 2). 


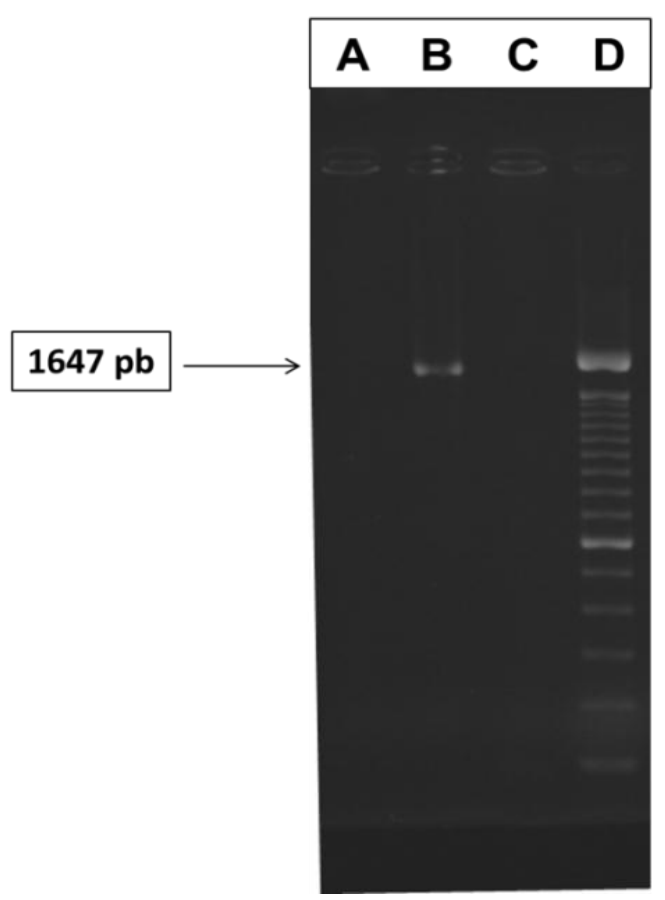

Figura 2 - Eletroforese dos produtos de PCR correspondentes ao gene hexon do HEV. Coluna A: Amostra de campo negativa; B: Controle positivo; C: Controle negativo; D: Padrão de peso molecular (Ladder 100 pb, LGC biotecnologia ${ }^{\circledR}$ )

\subsubsection{Astrovírus tipo 1 (TAstV-1)}

A técnica de PCR utilizada foi capaz de detectar o DNA do TAstV-1 produzindo um fragmento de 251 pb, observado após a eletroforese em gel de agarose $1,5 \%$ (Figura 3). 


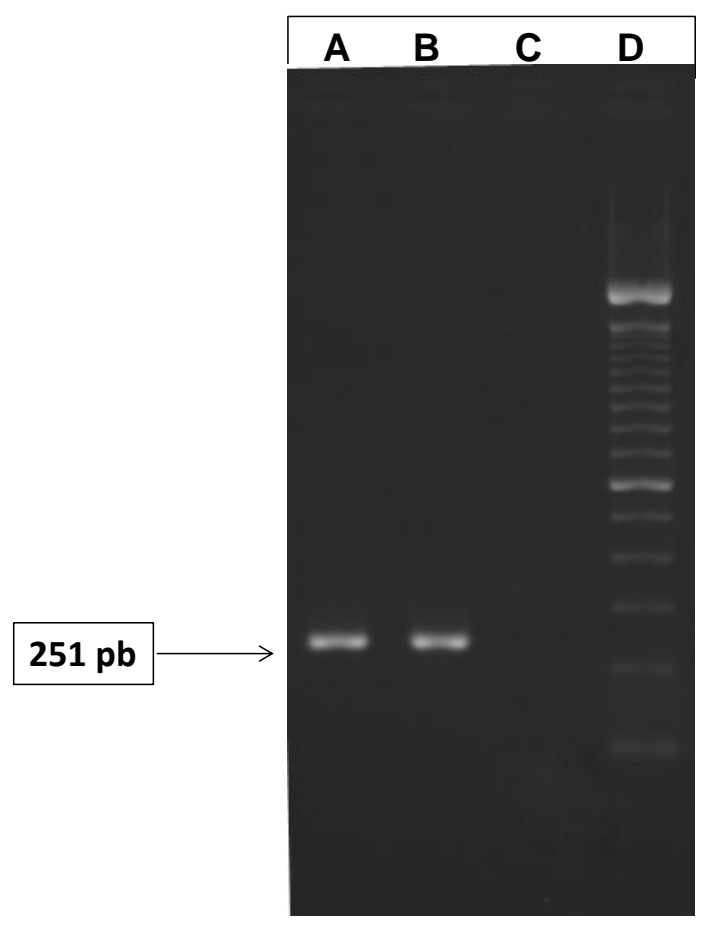

Figura 3 - Eletroforese dos produtos de PCR correspondentes ao gene da polimerase do TAstV-1. Coluna A: Amostra de campo; B: Controle positivo; C: Controle negativo; D: Padrão de peso molecular (Ladder 100 pb, LGC biotecnologiaß)

\subsubsection{Astrovírus tipo 2 (TAstV-2)}

A técnica de PCR utilizada foi capaz de detectar o DNA do TAstV-2 produzindo um fragmento de 802 pb, observado após a eletroforese em gel de agarose $1,5 \%$ (Figura 4). 


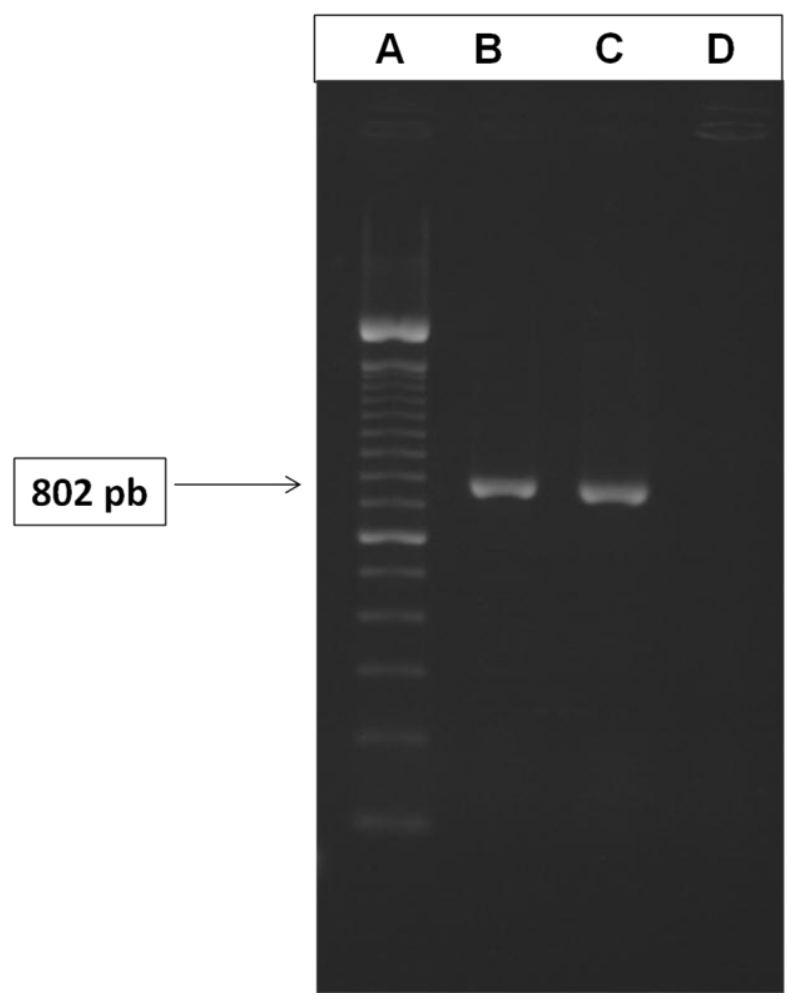

Figura 4 - Eletroforese dos produtos de PCR correspondentes ao gene da polimerase do TAstV-2. Coluna A: Padrão de peso molecular (Ladder 100 pb, LGC biotecnologiaß); B: Controle positivo; C: Amostra de campo; D: Controle negativo

\subsubsection{Vírus da nefrite aviária (ANV)}

A técnica de PCR utilizada foi capaz de detectar o DNA do ANV produzindo um fragmento de 473 pb, observado após a eletroforese em gel de agarose 1,5\% (Figura 5). 


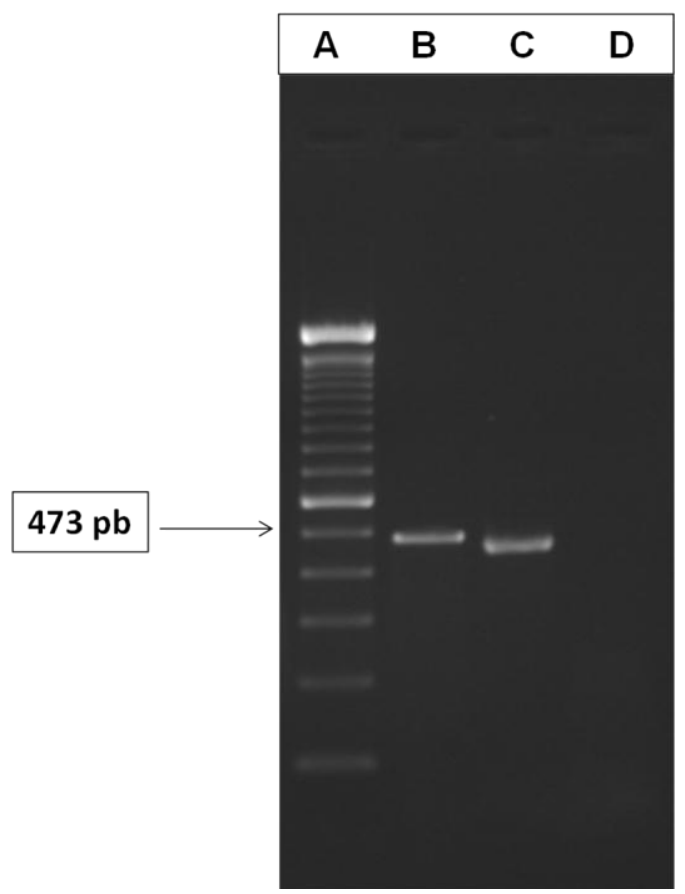

Figura 5 - Eletroforese dos produtos de PCR correspondentes ao gene da polimerase do ANV. Coluna A: Padrão de peso molecular (Ladder 100 pb, LGC biotecnologia®); B: Amostra de campo; C: Controle positivo; D: Controle negativo

\subsubsection{Coronavírus de perus (TCoV)}

A técnica de PCR utilizada foi capaz de detectar o DNA do TCoV produzindo um fragmento de 179 pb, observado após a eletroforese em gel de agarose 1,5\% (Figura 6). 


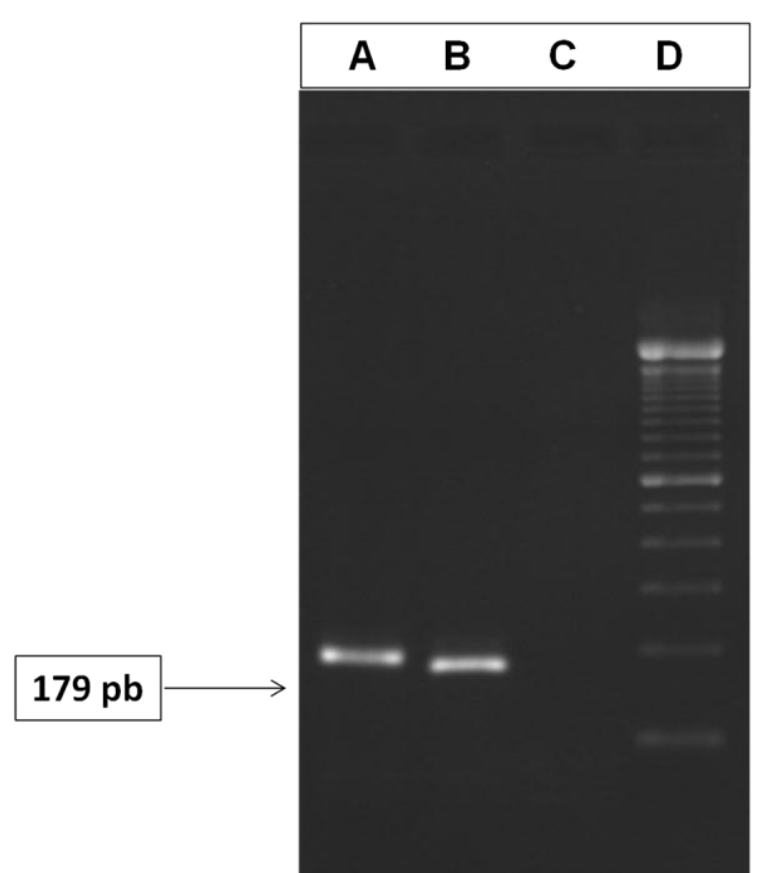

Figura 6 - Eletroforese dos produtos de PCR correspondentes à região 3' UTR do TCoV. Coluna A: Amostra de campo; B: Controle positivo; C: Controle negativo; D: Padrão de peso molecular (Ladder 100 pb, LGC biotecnologiaß)

\subsubsection{Reovírus}

A técnica de PCR utilizada foi capaz de detectar o DNA do Reovírus produzindo um fragmento de 1120 pb, observado após a eletroforese em gel de agarose $1,5 \%$ (Figura 7 ). 


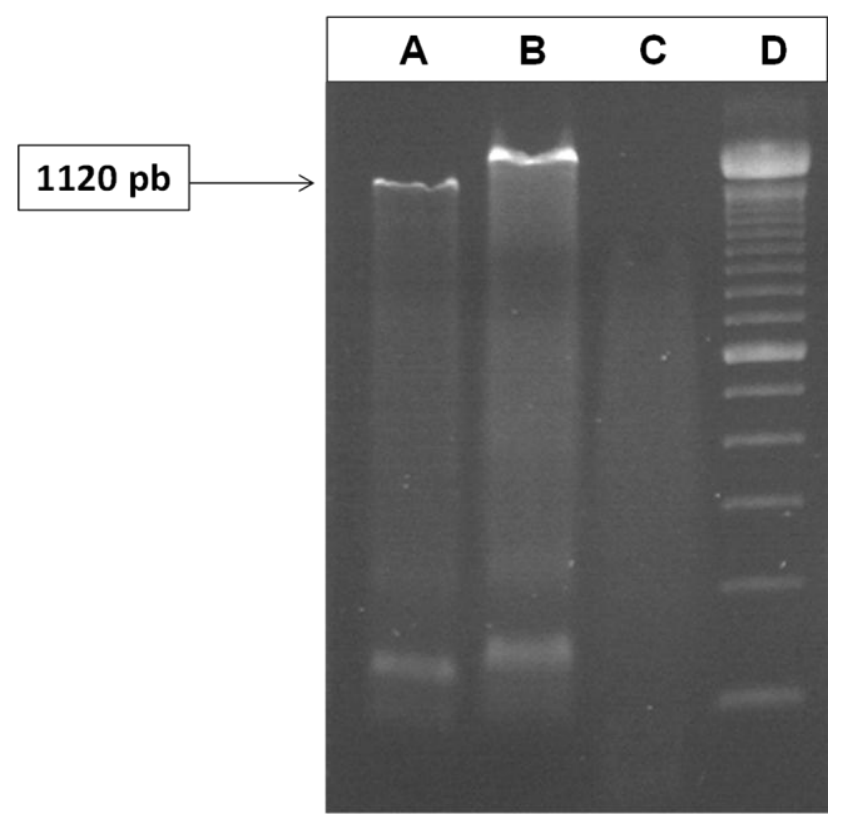

Figura 7 - Eletroforese dos produtos de PCR correspondentes ao gene S4 do Reovírus. Coluna A: Amostra de campo; B: Controle positivo; C: Controle negativo; D: Padrão de peso molecular (Ladder 100 pb, LGC biotecnologia ${ }^{\circledR}$ )

\subsubsection{Rotavírus}

A técnica de PCR utilizada foi capaz de detectar o DNA do Rotavírus produzindo um fragmento de 630 pb, observado após a eletroforese em gel de agarose $1,5 \%$ (Figura 8 ). 


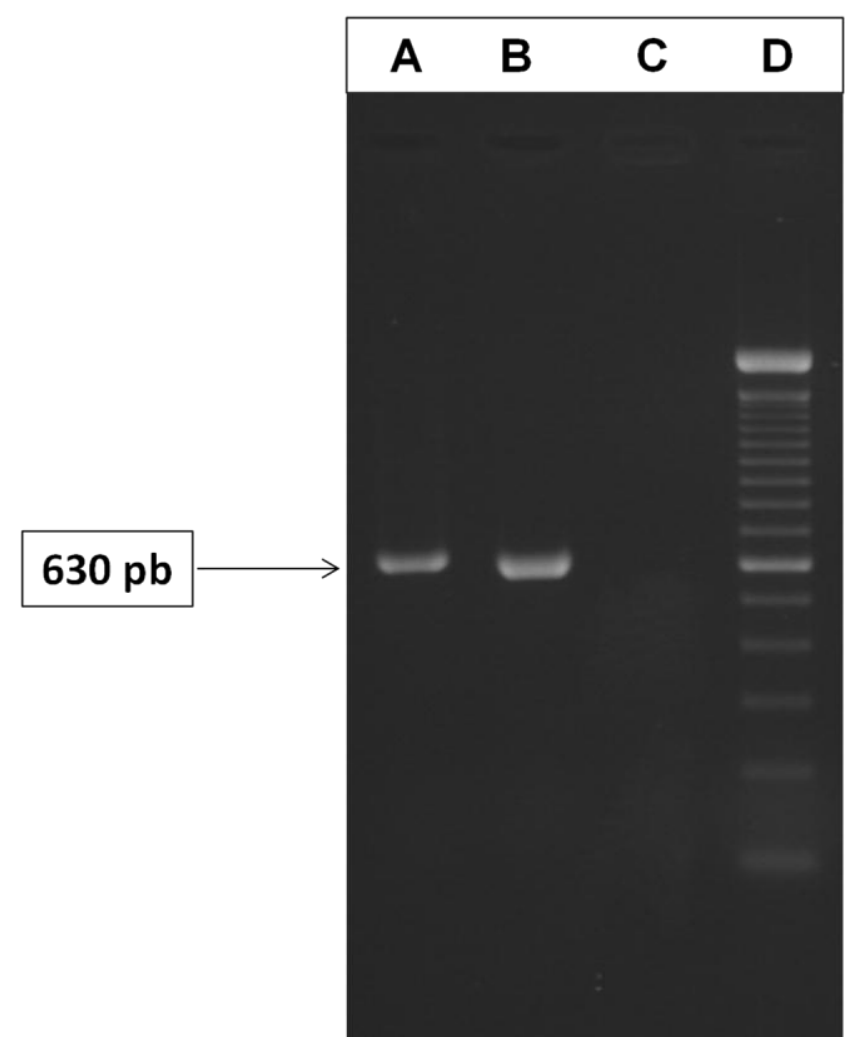

Figura 8 - Eletroforese dos produtos de PCR correspondentes ao gene NSP4 do Rotavírus. Coluna A: Amostra de campo; B: Controle positivo; C: Controle negativo; D: Padrão de peso molecular (Ladder 100 pb, LGC biotecnologia $\AA$ )

\subsection{FREQUÊNCIA DE DETECTAÇÃO VIRAL}

Foram analisadas, através da técnica de PCR, 76 amostras de intestino para a detecção de vírus entéricos. Determinou-se que 71 amostras (93,4\%) foram positivas para um ou mais vírus estudados e cinco (05) amostras $(6,6 \%)$ foram negativas. O gráfico 1 ilustra estes resultados. Os resultados de detecção individual para cada vírus constam no apêndice $B$. 


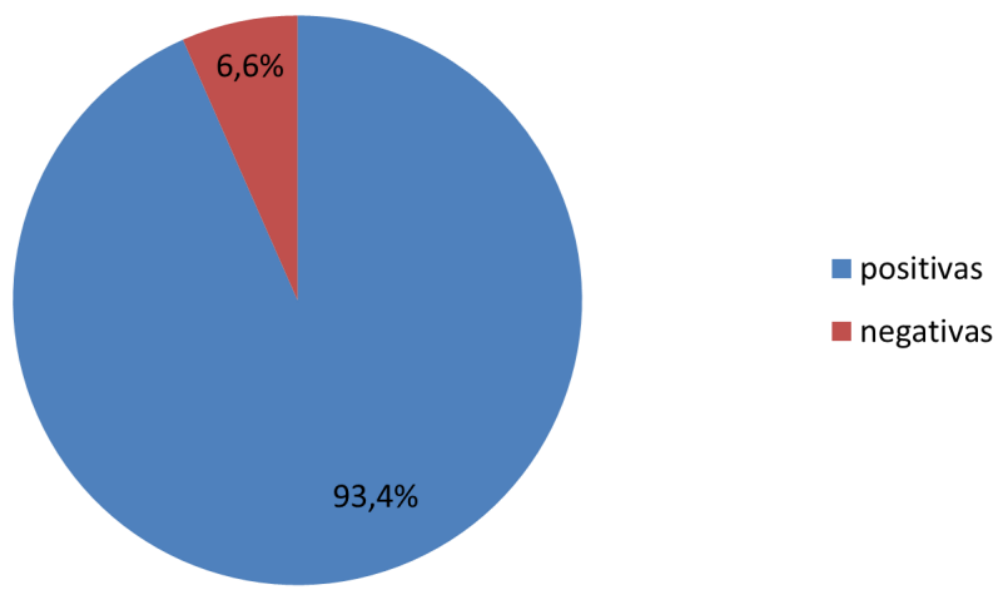

Gráfico 1 - Percentual de positividade na detecção de vírus entéricos

Em algumas amostras houve a deteç̧ão de um vírus isoladamente (com a exceção do TAV, HEV e Reovírus), mas em outras ocorreram associações de dois a seis vírus. A presença de vírus em associação foi mais frequente, principalmente a ocorrência de três e quatro vírus por amostra. Nas 76 amostras de fezes o TAstV-1 foi o vírus mais encontrado $(64,5 \%)$, o TCoV foi detectado em segundo $(55,3 \%)$ e o Rotavírus em terceiro $(52,6 \%)$, sendo ainda o vírus mais detectado isoladamente nas amostras (6/76 amostras). TAstV-2 e ANV estiveram presentes em 44,7\% e $35,5 \%$ das amostras, respectivamente, enquanto que os menos detectados foram Reovírus $(7,9 \%)$ e TAV (5,3\%). Nenhuma amostra apresentou HEV. Os dados da frequência de detecção dos vírus estudados pelo total de amostras $(n=76)$ e a presença destes em associação estão demonstrados na tabela 9. O gráfico 2 ilustra o percentual de cada vírus detectado em ordem decrescente. 
Tabela 9 - Distribuição da frequência (total e relativa) dos vírus detectados individualmente ou em associação na amostra

\begin{tabular}{|c|c|c|c|c|c|c|c|c|}
\hline $\begin{array}{c}\text { Número de vírus } \\
\text { detectados }\end{array}$ & TAV & HEV & TAstV-1 & TAstV-2 & ANV & TCoV & Reovírus & Rotavírus \\
\hline Um vírus & 0 & 0 & 3 & 4 & 2 & 3 & 0 & 6 \\
\hline Dois vírus & 0 & 0 & 8 & 5 & 1 & 3 & 0 & 5 \\
\hline Três vírus & 0 & 0 & 14 & 7 & 5 & 10 & 3 & 9 \\
\hline Quatro vírus & 2 & 0 & 16 & 11 & 11 & 18 & 1 & 13 \\
\hline Cinco vírus & 0 & 0 & 6 & 5 & 6 & 6 & 2 & 5 \\
\hline Seis vírus & 2 & 0 & 2 & 2 & 2 & 2 & 0 & 2 \\
\hline $\begin{array}{l}\text { Total absoluto de } \\
\text { amostras } \\
\text { positivas }\end{array}$ & 4 & 0 & 49 & 34 & 27 & 42 & 6 & 40 \\
\hline $\begin{array}{l}\text { \% de cada vírus } \\
\text { no total de } \\
\text { amostras }(n=76)\end{array}$ & 5,3 & 0 & 64,5 & 44,7 & 35,5 & 55,3 & 7,9 & 52,6 \\
\hline
\end{tabular}

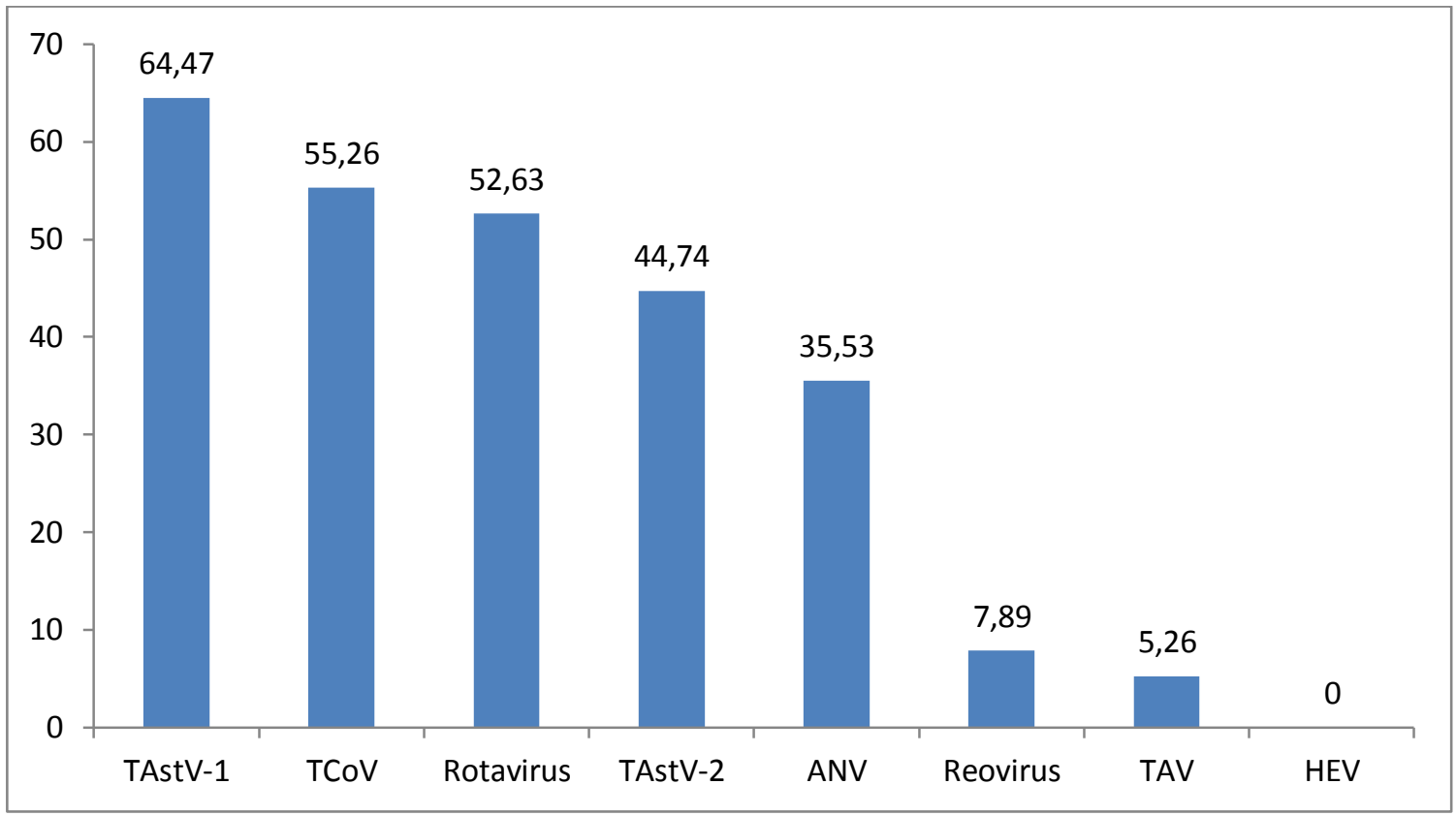

Gráfico 2 - Percentual de positividade de cada agente nas amostras analisadas

Verificou-se que, entre as 76 amostras estudadas, somente $18(23,7 \%)$ eram positivas para um vírus e $53(69,7 \%)$ tiveram a presença de mais de um agente e se verificou que Astrovírus (TAstV-1, TAstV-2 ou ANV) estiveram presentes em todas as amostras com associação de mais de um vírus. Com relação às associações, as mais frequentes foram:

- TAstV-1,TAstV-2,TCoV e Rotavírus (6/76);

- TAstV-1, ANV, TCoV e Rotavírus (5/76);

- TAstV-1 e Rotavírus (5/76);

- TAstV-1, TCoV e Rotavírus (4/76);

- TAstV-1, TAstV-2, ANV, TCoV e Rotavírus (4/76). 
Com relação à origem das amostras, se verificou que eram procedentes de Santa Catarina $(n=43)$, do Estado de Goiás $(n=26)$ e apenas sete $(n=07)$ amostras eram de Minas Gerais. Quanto à idade dos lotes se observou que 56 amostras eram de lotes na fase de terminação (5 a 18 semanas) e apenas 20 amostras eram de lotes em fase inicial de criação (1 a 4 semanas). A figura 10 ilustra a procedência destas amostras.

A frequência dos vírus detectados isoladamente e das diferentes associações encontra-se na tabela 10, assim como, a localidade e a idade dos lotes. 0 gráfico 3 mostra a frequência de detecção de um ou mais vírus nas amostras estudadas.

Os dados encontrados, com respeito ao número de vírus em associação, determinaram uma curva com distribuição normal, onde houve maior concentração de amostras com a detecção de um (01), três (03) ou quatro (04) vírus. 
Tabela 10 - Distribuição da frequência dos vírus detectados individualmente e as diferentes associações encontradas nas amostras estudadas, com relação à localidade e idade do lote

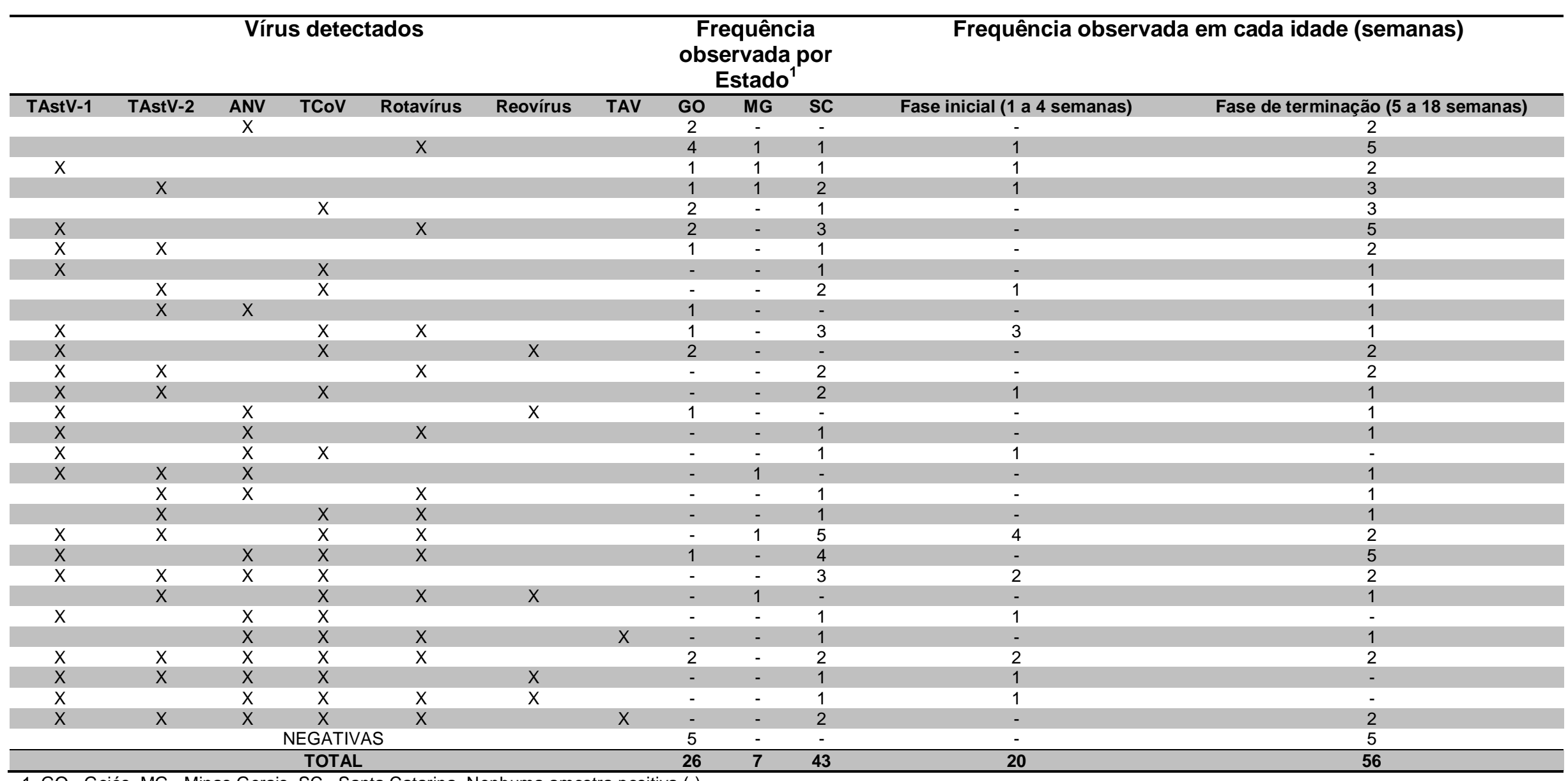




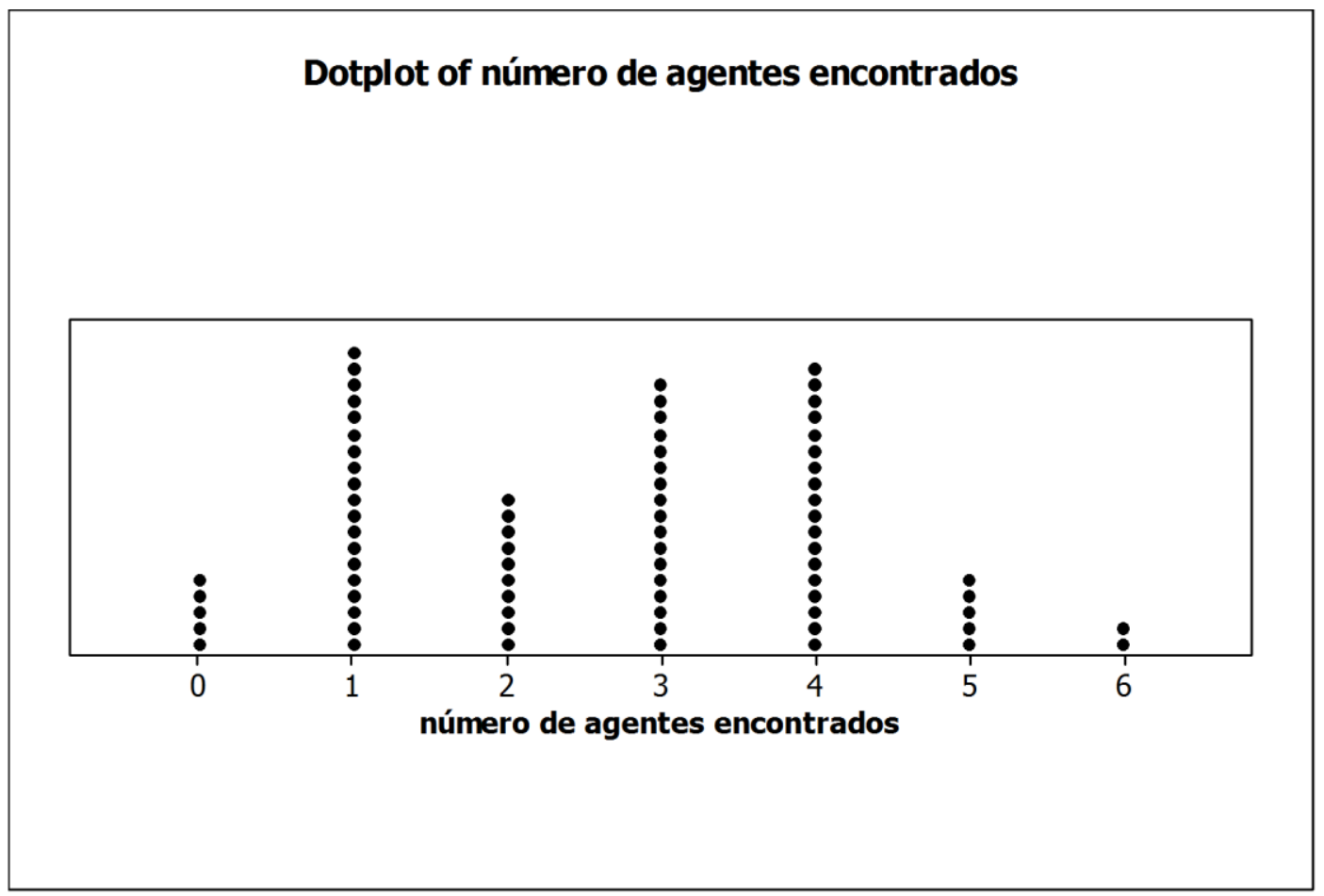

Gráfico 3 - Frequência de detecção de um ou mais vírus nas amostras estudadas ( $n=76$ )

\subsection{DISTRIBUIÇÃO GEOGRÁFICA DAS AMOSTRAS}

De acordo com o relatório, do ano de 2009, da União Brasileira de Avicultura (UBA), a maior produção de perus de corte ocorreu no Estado do Paraná, sendo esta de $46 \%$ da produção brasileira. Nos Estados de Santa Catarina e Minas Gerais esta foi de $16 \%$ e nos Estados de Goiás e Rio Grande do Sul estas foram, respectivamente, 13 e 9\%. A figura 9 ilustra a distribuição da produção brasileira de perus comerciais por Estados produtores, enquanto a figura 10 demonstra a procedência das amostras enviadas ao laboratório de Ornitopatologia da USP. 


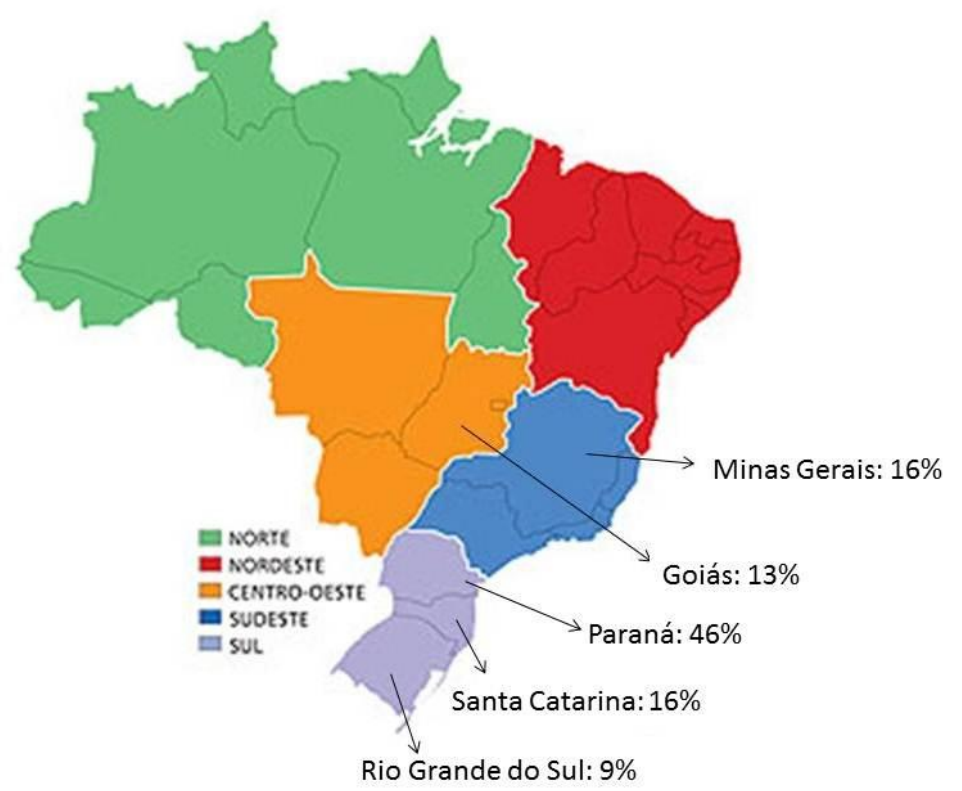

Figura 9 - Distribuição da produção brasileira de perus comerciais (\% de cabeças de perus por Estado produtor). Fonte: UBA, relatório anual 2009

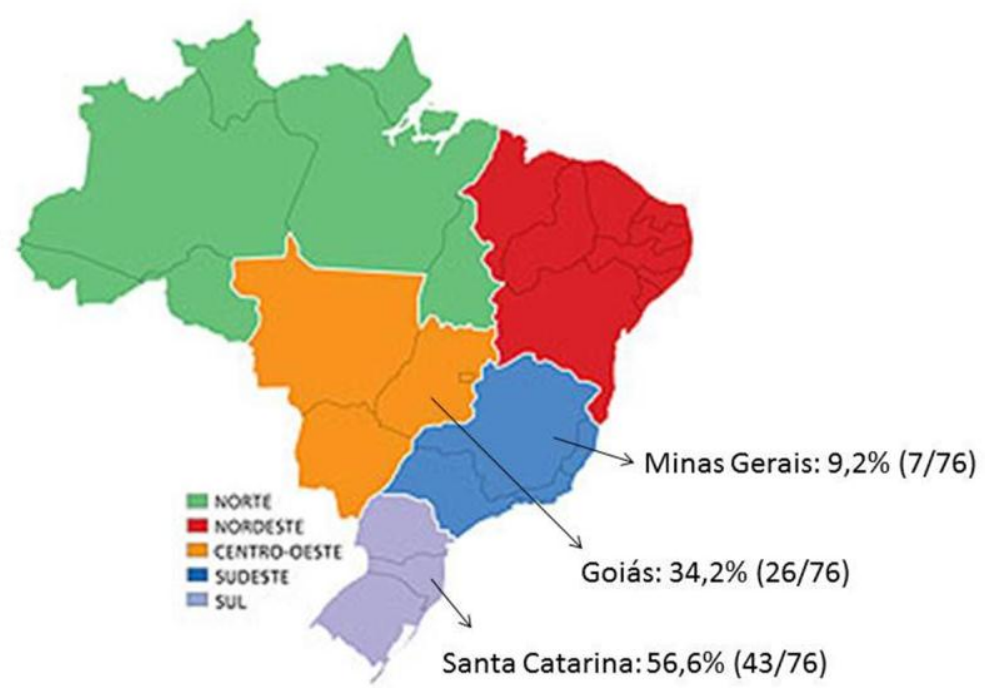

Figura 10 - Procedência das amostras de intestinos de perus enviadas ao laboratório de Ornitopatologia (USP) 
Considerando o número de agentes detectados por Estado produtor, a análise estatística mostrou que o Rotavírus ocorreu com maior frequência (4/26) em Santa Catarina $(p<0,05)$, sendo este o local onde houve também a maior frequência de detecção de um único agente $(p<0,05)$. As amostras provenientes deste Estado também apresentaram média de número de vírus detectados por amostra significativamente maior do que aquelas encontradas no Estado de Goiás $(p<0,05)$. Apenas no Estado de Goiás ocorreram amostras negativas (5/26).

Em Santa Catarina foi observada uma alta frequência de amostra com três ou quatro vírus, sendo as associações mais frequentes: TAstV-1,TAstV-2, TCoV e Rotavírus (5/43) e TAstV-1, ANV, TCoV e Rotavírus (4/43). Não foi possível se determinar a frequência de um vírus ou de associação de vírus entre as amostras provenientes de Minas Gerais. A tabela 11 apresenta a frequência de vírus de acordo com a origem da amostra, assim como o resultado da análise estatística das mesmas. O gráfico 4 ilustra essa distribuição.

Tabela 11 - Distribuição da frequência do número de vírus detectados em associação pela localidade (Estado) de procedência das amostras

\begin{tabular}{ccccccccc}
\hline $\begin{array}{c}\text { Localidades } \\
\text { (Estado) }\end{array}$ & \multicolumn{9}{c}{ Número de vírus detectados em associação } & & $\begin{array}{c}\text { Número de vírus } \\
\text { detectados (média } \pm \\
\text { desvio padrão) }\end{array}$ \\
\cline { 2 - 8 } & Negativa & Um & Dois & Três & Quatro & Cinco & Seis & \\
\hline Goiás & 5 & 10 & 4 & 4 & 1 & 2 & 0 & $1,73 \pm 1,48 \mathrm{~b}$ \\
Minas Gerais & 0 & 3 & 0 & 1 & 3 & 0 & 0 & $2,57 \pm 1,51$ ab \\
Santa Catarina & 0 & 5 & 7 & 11 & 14 & 4 & 2 & $3,14 \pm 1,33 \mathrm{a}$ \\
\hline Total & 5 & 18 & 11 & 16 & 18 & 6 & 2 & \\
\hline
\end{tabular}

Letras diferentes na coluna indicam diferença estatística significativa $(p<0,05)$. 


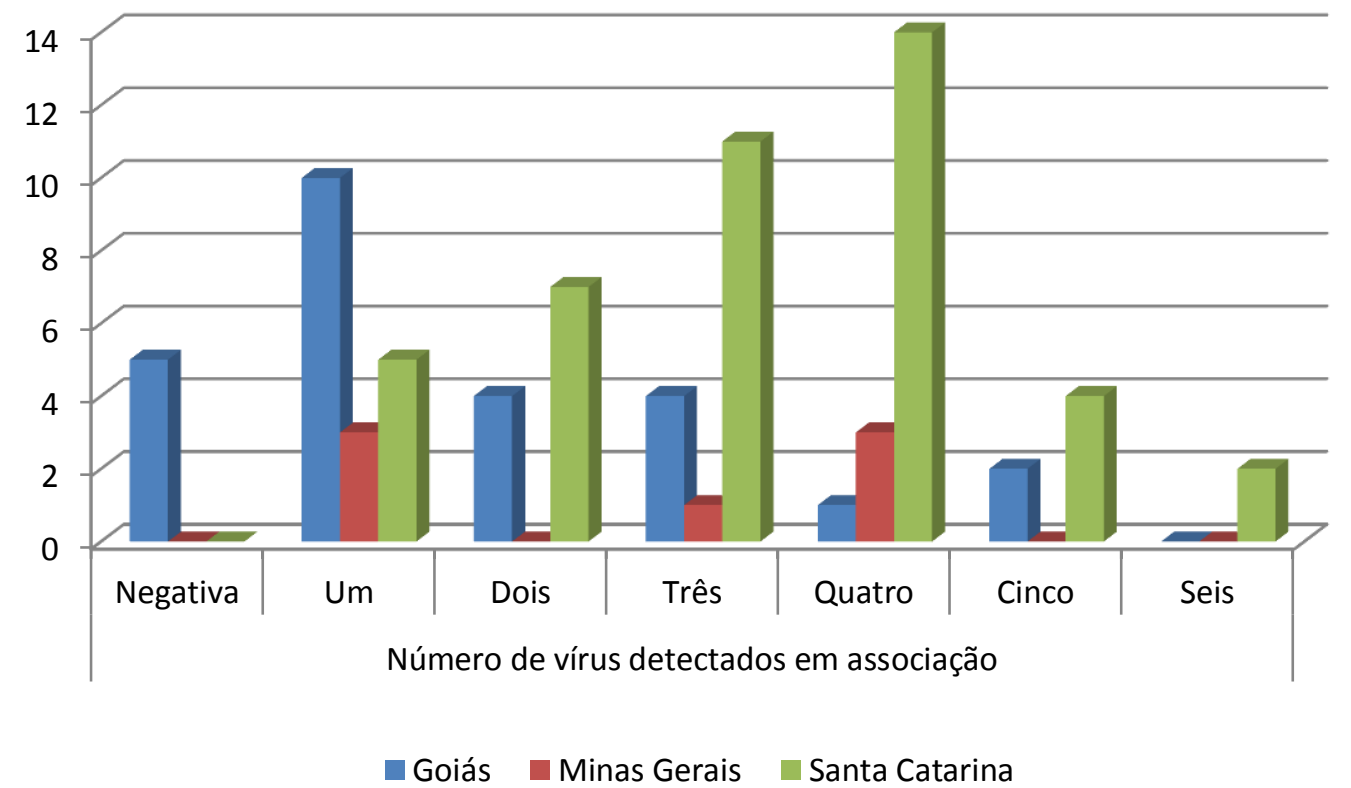

Gráfico 4 - Distribuição das amostras quanto à positividade para um ou mais vírus, pela procedência da amostra

Com relação a época do ano em que houve a coleta das amostras bem como a relação de positividade com o Estado de procedência, verificou-se a presença de grande número de amostras coletadas durante as estações de Outono (30 amostras) e Inverno (24 amostras), sendo que no caso do Outono a maioria tinha a procedência de Santa Catarina (19 amostras), enquanto que apenas oito (8, sendo 7 positivas para pelo menos um vírus e 1 negativa) eram de Goiás e três (3) de Minas Gerais. Já no Inverno as amostras procedentes de Goiás foram a maioria (14 amostras positivas e 4 negativas) e seis (6) amostras positivas de Santa Catarina. Nos meses de Verão houve detecção viral em 15 amostras, sendo onze (11) de Santa Catarina e quatro (4) de Minas Gerais, e nos meses de primavera somente sete amostras positivas foram observadas no Estado de Santa Catarina. A tabela 12 mostra esses resultados. 
Tabela 12 - Distribuição das amostras positivas e negativas para vírus entéricos com relação ao Estado de origem das mesmas e estação do ano em que foi realizada a coleta

\begin{tabular}{|c|c|c|c|c|c|c|c|}
\hline \multirow{3}{*}{$\begin{array}{c}\text { Estações } \\
\text { do ano }\end{array}$} & \multicolumn{6}{|c|}{ Localidade (Estado) } & \multirow{3}{*}{ Total } \\
\hline & \multicolumn{2}{|c|}{ Goiás } & \multicolumn{2}{|c|}{ Minas Gerais } & \multicolumn{2}{|c|}{ Santa Catarina } & \\
\hline & Positivas & Negativas & Positivas & Negativas & Positivas & Negativas & \\
\hline Primavera & 0 & 0 & 0 & 0 & 7 & 0 & 7 \\
\hline Verão & 0 & 0 & 4 & 0 & 11 & 0 & 15 \\
\hline Outono & 7 & 1 & 3 & 0 & 19 & 0 & 30 \\
\hline Inverno & 14 & 4 & 0 & 0 & 6 & 0 & 24 \\
\hline Total & 21 & 5 & 7 & 0 & 43 & 0 & 76 \\
\hline
\end{tabular}

\subsection{AVALIAÇÃO PELA IDADE DOS LOTES}

Os sinais entéricos e alterações zootécnicas foram relatados em todos os lotes em fase inicial (1 a 4 semanas), e não houve nenhum lote sem sinal clínico. Considerando o número de vírus detectados, houve maior detecção de três, quatro ou cinco vírus, sendo TAstV-1 e TCoV os que ocorreram com maior frequência.

Quando os dados referentes à fase de terminação (5 a 18 semanas) foram analisados, verificou-se que $50 \%$ das amostras (28/56) eram de lotes sem sinais clínicos e três amostras eram provenientes de lotes sem informação sobre o estado de saúde. Nas amostras com relatos de sinais clínicos (25/56) os sinais entéricos e alterações zootécnicas foram os mais relatados (17 e 19 relatos, respectivamente), porém, estes ocorreram com menor frequência do que na fase inicial (1 a 4 semanas), onde todas as amostras tinham relato desses sinais. Verificou-se alta frequência de detecção de um vírus (15/56), sendo detectados com maior frequência, TAstV-1, TCoV e Rotavírus. Comparando-se as duas fases de crescimento se observa que todos os vírus foram detectados com menor frequência na fase de terminação do que na inicial, exceto o TAV que ocorreu com uma frequência maior entre 5 e 18 semanas. As tabelas 13 e 14 e o gráfico 6 apresentam estes resultados.

No gráfico 5 se encontra a distribuição do número de vírus detectados por amostra, com relação às diferentes idades ou fases de crescimento, enquanto o gráfico 6 mostra a distribuição da frequência de detecção de cada agente nestas fases. 
Através de análise de variância destes dados, seguida do teste de Tukey para a comparação das médias, foi verificada diferença estatística significativa entre as duas fases de crescimento $(p=0,047)$, ao nível de significância $5 \%$, onde o número de vírus detectados em associação foi maior para aves de 1 a 4 semanas (na fase inicial) com média de $3,41 \pm 1,36$ do que em aves com 5 a 18 semanas $(2,41 \pm$ 1,55). A tabela 15 apresenta estes resultados. 
Tabela 13 - Distribuição da frequência dos sinais clínicos relatados e número de vírus detectados nas amostras com relação à idade do lote

\begin{tabular}{|c|c|c|c|c|c|c|c|c|c|c|c|c|c|c|}
\hline \multirow[t]{2}{*}{ Idades } & \multirow{2}{*}{$\begin{array}{l}\text { Número } \\
\text { de lotes }\end{array}$} & \multicolumn{6}{|c|}{$\begin{array}{c}\text { Número de lotes com sinais } \\
\text { clínicos }^{1}\end{array}$} & \multicolumn{7}{|c|}{ Número de vírus detectados por amostra (\%) ${ }^{2}$} \\
\hline & & TGI & $\mathbf{A Z}$ & $A C$ & $O A$ & SS & SI & $\begin{array}{l}\text { Amostras } \\
\text { negativas }\end{array}$ & Um & Dois & Três & Quatro & Cinco & Seis \\
\hline $\begin{array}{c}1 \text { a } 4 \\
\text { semanas }\end{array}$ & 20 & 20 & 20 & 11 & 2 & 0 & 0 & $0(0 \%)$ & $3(15 \%)$ & $1(5 \%)$ & $5(25 \%)$ & $7(35 \%)$ & $4(20 \%)$ & $0(0 \%)$ \\
\hline $\begin{array}{c}5 \text { a } 18 \\
\text { semanas }\end{array}$ & 56 & 17 & 19 & 11 & 8 & 28 & 3 & $5(8,92 \%)$ & $\begin{array}{c}15 \\
(26,8 \% \%)\end{array}$ & $\begin{array}{c}10 \\
(17,9 \%)\end{array}$ & $\begin{array}{c}11 \\
(19,6 \%)\end{array}$ & $\begin{array}{c}11 \\
(19,6 \%)\end{array}$ & $2(3,6 \%)$ & $2(3,6 \%)$ \\
\hline TOTAL & 76 & 37 & 39 & 22 & 10 & 28 & 3 & 5 & 18 & 11 & 16 & 18 & 6 & 2 \\
\hline
\end{tabular}

1.TGl= sinais entéricos; $\mathrm{AZ}=$ alterações zootécnicas; $\mathrm{AC}=$ alterações comportamentais; $\mathrm{OA}=$ outras alterações; $\mathrm{SS}=$ sem sinais clínicos; $\mathrm{Sl=sem}$ informação; 2 . $\mathrm{O}$ percentual foi calculado com base no número de lotes.

Tabela 14 - Distribuição da frequência dos vírus detectados nas amostras e sinais clínicos relatados com relação à idade do lote

\begin{tabular}{|c|c|c|c|c|c|c|c|c|c|c|c|c|c|c|}
\hline \multirow{2}{*}{$\begin{array}{l}\text { Idades } \\
\text { em } \\
\text { semanas }\end{array}$} & \multirow{2}{*}{$\begin{array}{l}\text { Número } \\
\text { de lotes }\end{array}$} & \multicolumn{6}{|c|}{$\begin{array}{c}\text { Número de lotes com sinais } \\
\text { clínicos }^{1}\end{array}$} & \multicolumn{7}{|c|}{ Vírus detectados $(\%)^{2}$} \\
\hline & & TGI & $\mathbf{A Z}$ & AC & OA & SS & SI & TAV & TAstV-1 & TAstV-2 & ANV & TCoV & Reovírus & Rotavírus \\
\hline 1 a 4 & 20 & 20 & 20 & 11 & 2 & 0 & 0 & $1(5 \%)$ & $17(85 \%)$ & $12(60 \%)$ & $8(40 \%)$ & $17(85 \%)$ & $2(10 \%)$ & $11(55 \%)$ \\
\hline 5 a 18 & 56 & 17 & 19 & 11 & 8 & 28 & 3 & $3(5,4 \%)$ & $\begin{array}{c}32 \\
(57,1 \%)\end{array}$ & $\begin{array}{c}22 \\
(39,3 \%)\end{array}$ & $\begin{array}{c}19 \\
(33,9 \%)\end{array}$ & $\begin{array}{c}25 \\
(44,6 \%)\end{array}$ & $4(7,1 \%)$ & $\begin{array}{c}29 \\
(51,8 \%)\end{array}$ \\
\hline TOTAL & 76 & 37 & 39 & 22 & 10 & 28 & 3 & 4 & 49 & 34 & 27 & 42 & 6 & 40 \\
\hline
\end{tabular}

1.TGI= sinais entéricos; $A Z=$ alterações zootécnicas; $A C=$ alterações comportamentais; $\mathrm{OA}=$ outras alterações; $\mathrm{SS}=$ sem sinais clín icos; $\mathrm{SI}=$ sem informação; 2 . O percentual foi calculado com base no número de lotes. 
Boxplot do número de vírus detectados por amostra

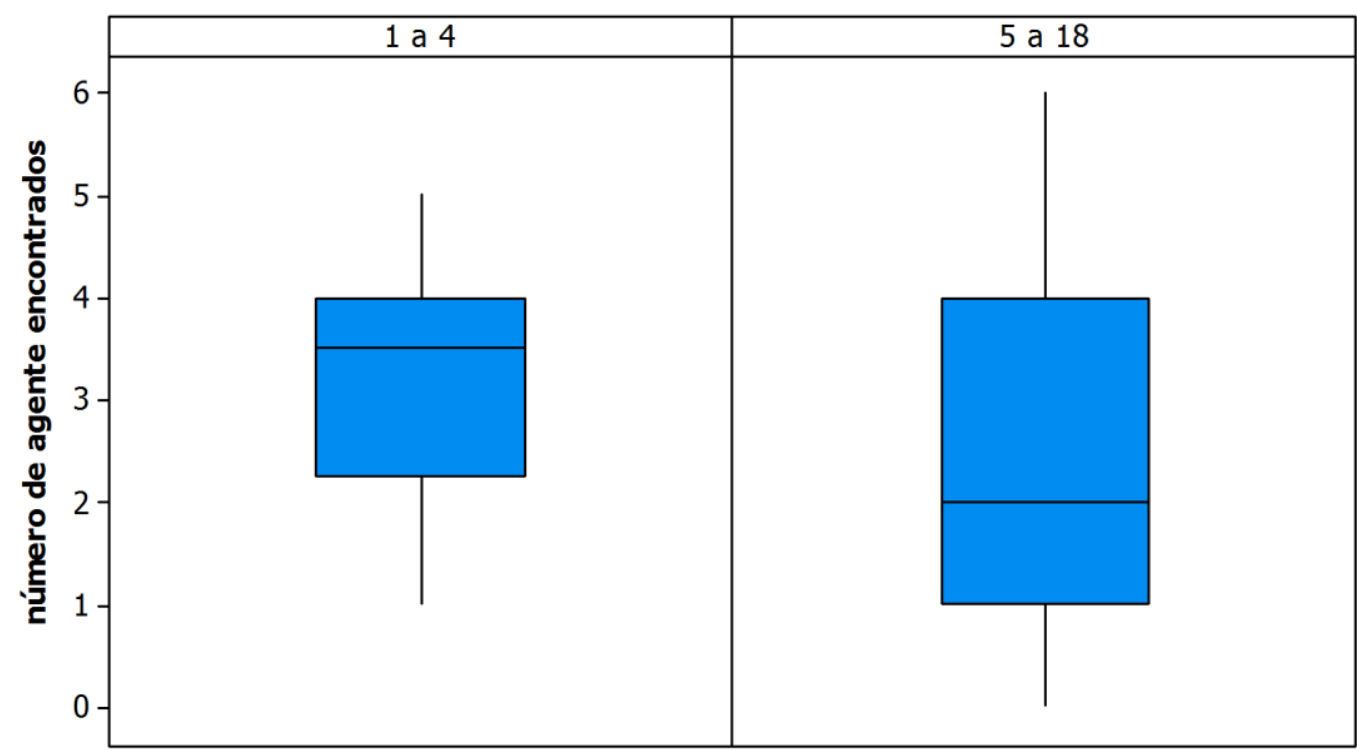

Variável: Idade (semanas)

Gráfico 5 - Boxplot da distribuição do número de vírus detectados por amostra, conforme a idade dos lotes em semanas

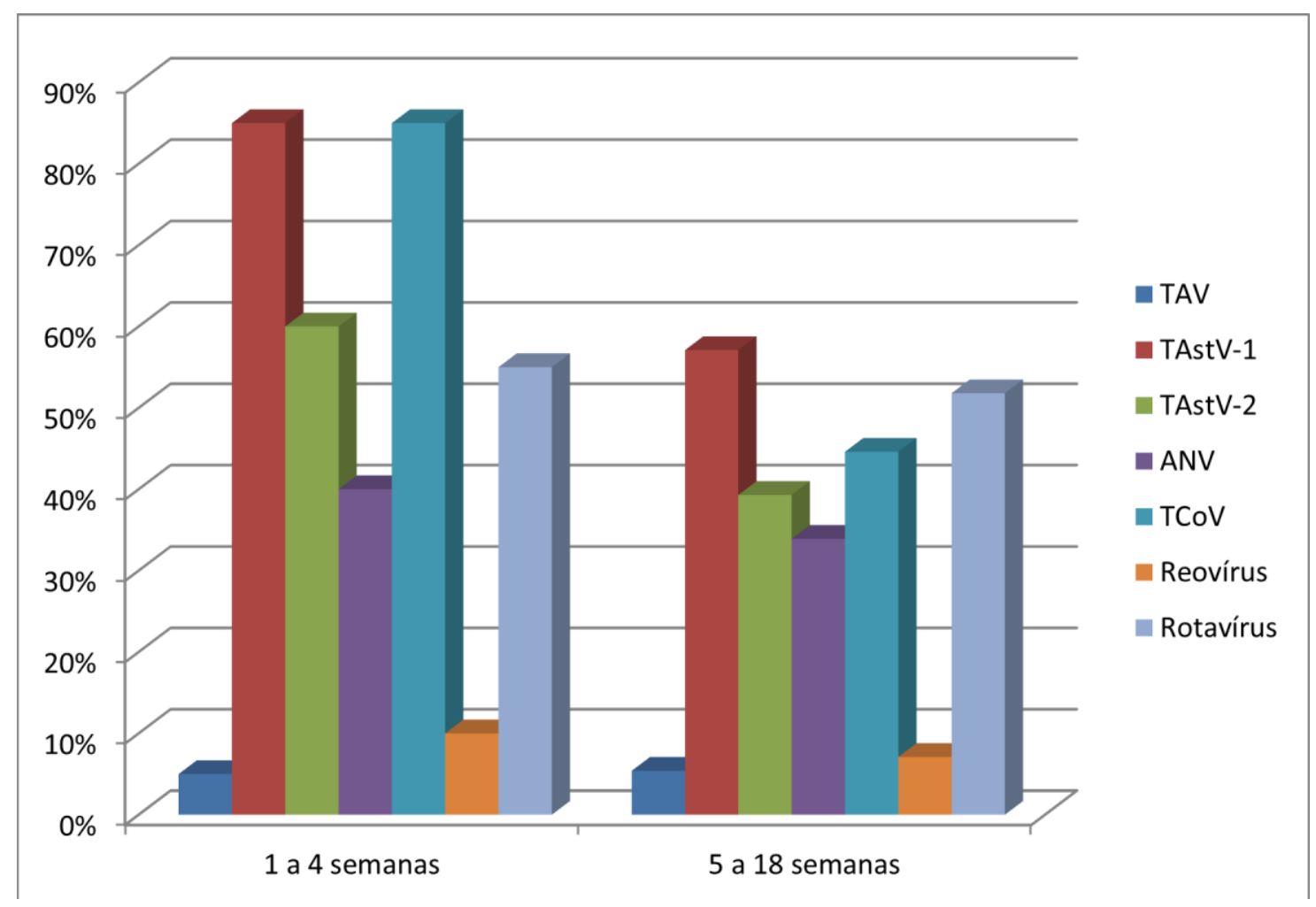

Gráfico 6 - Percentual de detecção dos vírus estudados com relação à idade dos lotes 
Tabela 15 - Análise estatística da média do número de vírus detectados por amostra, pela idade das aves

\begin{tabular}{ccc}
\hline Idades em semanas & Número de lotes & $\begin{array}{c}\text { Média do número de vírus } \\
\text { detectados em associação } \\
\text { (média } \pm \text { desvio padrão) }\end{array}$ \\
\hline 1 a 4 & 20 & $3,20 \pm 1,36$ a \\
5 a 18 & 56 & $2,41 \pm 1,55 \mathrm{~b}$ \\
\hline
\end{tabular}

Letras diferentes na coluna indicam diferença estatística significativa $(p<0,05)$.

\subsection{AVALIAÇÃO PELOS SINAIS CLÍNICOS}

Do total de amostras $(n=76)$ estudadas, 45 tiveram relato de algum sinal clínico no lote, 28 eram amostras de lotes sem sinais clínicos e três amostras não continham informação sobre o estado de saúde do lote.

Verificou-se que todas as amostras estudadas com relatos de sinais clínicos nos lotes $(n=45)$ foram positivas para pelo menos um dos vírus estudados, enquanto que as amostras provenientes de lotes sem sinais clínicos $(n=28)$, cinco foram negativas e 23 positivas para pelo menos um vírus. Esses dados estão descritos na tabela 16 que mostra a relação entre a presença de sinais clínicos no lote e a detecção de vírus na amostra.

Houve maior frequência de TAstV-1 (73,3\%), TCoV (71,1\%), TAstV-2 (64,4\%) e Rotavírus $(57,8 \%)$ nas amostras com sinais clínicos (45), enquanto naquelas sem sinais clínicos os vírus mais frequentes foram TAstV-1 (46,4\%) e Rotavírus (39,3\%). TAV somente foi detectado em aves com sinais clínicos. Em ambos os casos o TAstV-1 foi o mais frequente. Todos os vírus foram detectados com menor frequência nas amostras sem sinais clínicos, embora o Reovírus tenha sido uma exceção. Ocorreu menor detecção de TAstV-2 e TCoV entre as amostras sem sinais clínicos e quando estas foram comparadas com aquelas que apresentavam estes sinais, se verificou uma diminuição em $40 \%$ na detecção desses vírus. Três lotes não tinham informações sobre o estado de saúde das aves. Os dados de frequência absoluta e relativa da detecção de todos os vírus com relação aos sinais clínicos estão demonstrados na tabela 17 e no gráfico 7 . 
Tabela 16 - Distribuição da freqüência de detecção viral pela presença de sinais clínicos nos lotes

\begin{tabular}{lrrr}
\hline Sinais clínicos & $\begin{array}{l}\text { Detecção positiva de } \\
\text { pelo menos um vírus }\end{array}$ & $\begin{array}{r}\text { Nenhum agente } \\
\text { detectado }\end{array}$ & Total \\
\hline Presentes & 45 & 0 & $\mathbf{4 5}$ \\
Ausentes & 23 & 5 & $\mathbf{2 8}$ \\
Sem informação & 3 & 0 & $\mathbf{3}$ \\
\hline Total & $\mathbf{7 1}$ & $\mathbf{5}$ & $\mathbf{7 6}$ \\
\hline
\end{tabular}

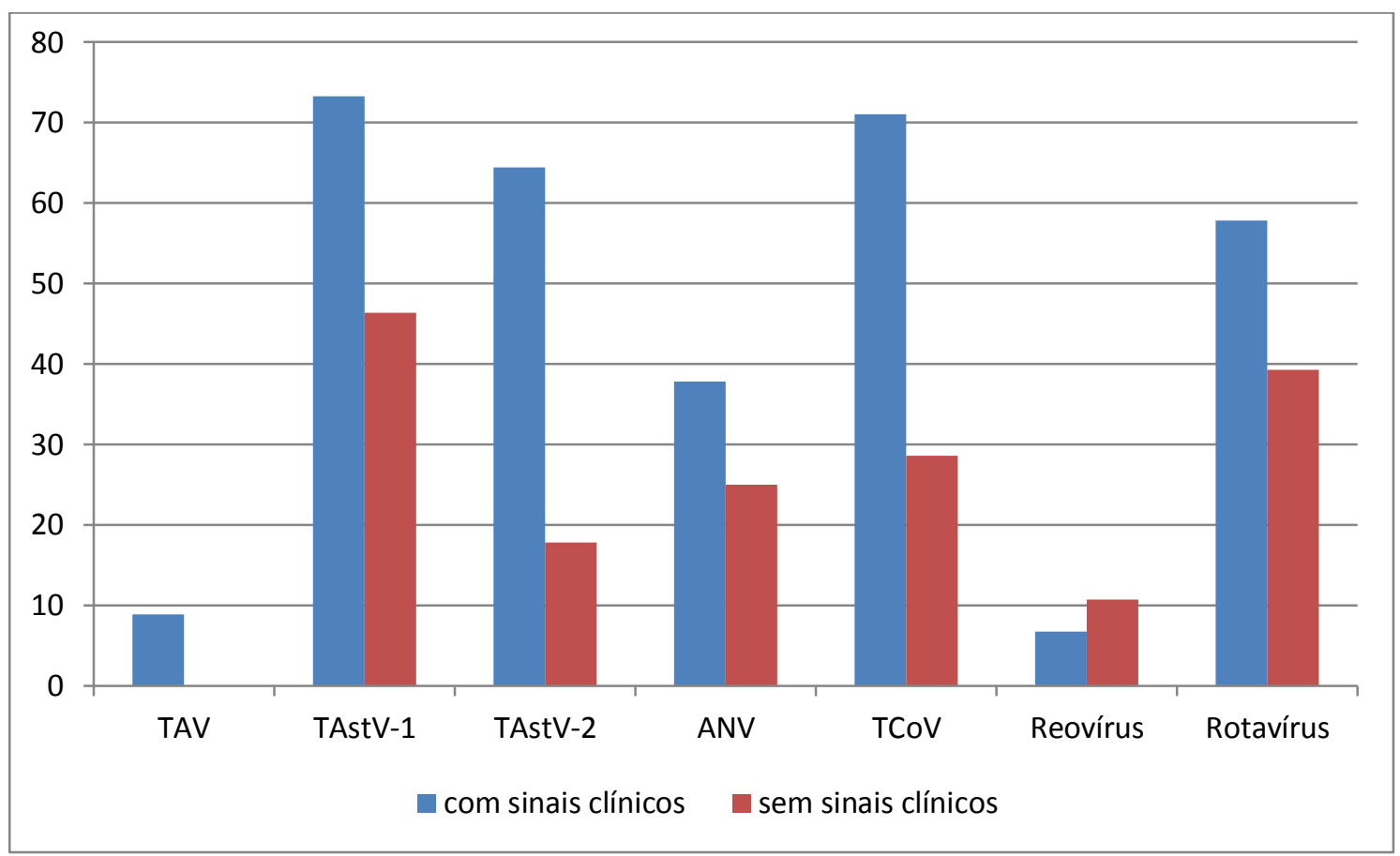

Gráfico 7 - Percentual da detecção dos vírus estudados com relação à presença de sinais clínicos nos lotes 
Tabela 17 - Distribuição da frequência da detecção dos vírus estudados pela presença de sinais clínicos nos lotes

\begin{tabular}{ccccccccc}
\hline \multirow{2}{*}{$\begin{array}{c}\text { Sinais } \\
\text { clínicos }\end{array}$} & $\begin{array}{c}\text { Número de } \\
\text { lotes }\end{array}$ & TAV & TAstV-1 & TAstV-2 & ANV & TCoV & Reovírus & Rotavírus \\
\cline { 3 - 9 }$y$ & 45 & $4(8,9 \%)$ & $33(73,3 \%)$ & $29(64,4 \%)$ & $17(37,8 \%)$ & $32(71,1 \%)$ & $3(6,7 \%)$ & $26(57,8 \%)$ \\
Presentes & 45 & $0(0 \%)$ & $13(46,4 \%)$ & $5(17,8 \%)$ & $7(25 \%)$ & $8(28,6 \%)$ & $3(10,7 \%)$ & $11(39,3 \%)$ \\
Ausentes & 28 & $0(0 \%)$ & $3(100 \%)$ & $0(0 \%)$ & $3(100 \%)$ & $2(66,7 \%)$ & $0(0 \%)$ & $3(100 \%)$ \\
$\begin{array}{c}\text { Sem } \\
\text { informação }\end{array}$ & 3 & $\mathbf{4}$ & $\mathbf{4 9}$ & $\mathbf{3 4}$ & $\mathbf{2 7}$ & $\mathbf{4 2}$ & $\mathbf{6}$ & $\mathbf{4 0}$ \\
\hline TOTAL & $\mathbf{7 6}$ & $\mathbf{4}$ & & & & &
\end{tabular}


Como mostra a tabela 18 , que descreve a relação entre o número de vírus detectados com os tipos de sinais clínicos relatados, os sinais entéricos (TGI) e alterações zootécnicas (AZ) foram os mais relatados no total de amostras (37 e 39 relatos, respectivamente) e apresentaram frequências semelhantes. Entre as 19 amostras onde ocorreu a detecção de um único agente, em onze não haviam relatos de sinais clínicos e as demais apresentavam alterações zootécnicas (AZ), sendo que seis apresentaram sinais entéricos (TGl) e em três ocorreram alterações comportamentais (AC). Nas amostras onde houve a detecção de quatro vírus $(\mathrm{n}=18)$, apenas uma amostra não apresentava sinal clínico, e entre as 17 amostras, 14 e 13 tinham relatos de TGI e AZ, respectivamente. Em doze que apresentavam sinais clínicos, verificou-se a presença de três vírus, sendo que em nove existiram relatos de TGI e AZ. Além disso, dentre as amostras com a detecção de cinco ou seis vírus todas aquelas que tiveram relatos de sinais clínicos apresentaram TGI, AZ e AC. O gráfico 8 ilustra a relação entre os sinais clínicos e o número de vírus detectados por amostra.

Tabela 18 - Relação entre os sinais clínicos relatados e o número de amostra com um ou mais vírus detectado

\begin{tabular}{|c|c|c|c|c|c|c|c|}
\hline \multirow{2}{*}{$\begin{array}{l}\text { Números de } \\
\text { vírus em } \\
\text { associação }\end{array}$} & \multirow{2}{*}{$\begin{array}{l}\text { Número } \\
\text { de lotes }\end{array}$} & \multicolumn{6}{|c|}{ Sinais clínicos ${ }^{\top}$} \\
\hline & & TGI & $\mathbf{A Z}$ & AC & OA & SS & SI \\
\hline Negativa & 5 & 0 & 0 & 0 & 0 & 5 & 0 \\
\hline Um vírus & 19 & 6 & 8 & 3 & 0 & 11 & 0 \\
\hline Dois vírus & 10 & 3 & 4 & 2 & 0 & 4 & 0 \\
\hline Três virus & 17 & 9 & 9 & 7 & 3 & 5 & 1 \\
\hline Quatro virus & 18 & 14 & 13 & 5 & 5 & 1 & 2 \\
\hline Cinco vírus & 6 & 4 & 4 & 4 & 1 & 2 & 0 \\
\hline Seis virus & 1 & 1 & 1 & 1 & 1 & 0 & 0 \\
\hline Total & 76 & 37 & 39 & 22 & 10 & 28 & 3 \\
\hline
\end{tabular}

1. TGI= sinais entéricos; $\mathrm{AZ}=$ alterações zootécnicas; $\mathrm{AC}=$ alterações comportamentais; $\mathrm{OA}=$ outras alterações; $\mathrm{SS}=$ sem sinais clínicos; $\mathrm{SI}=$ sem informação. 


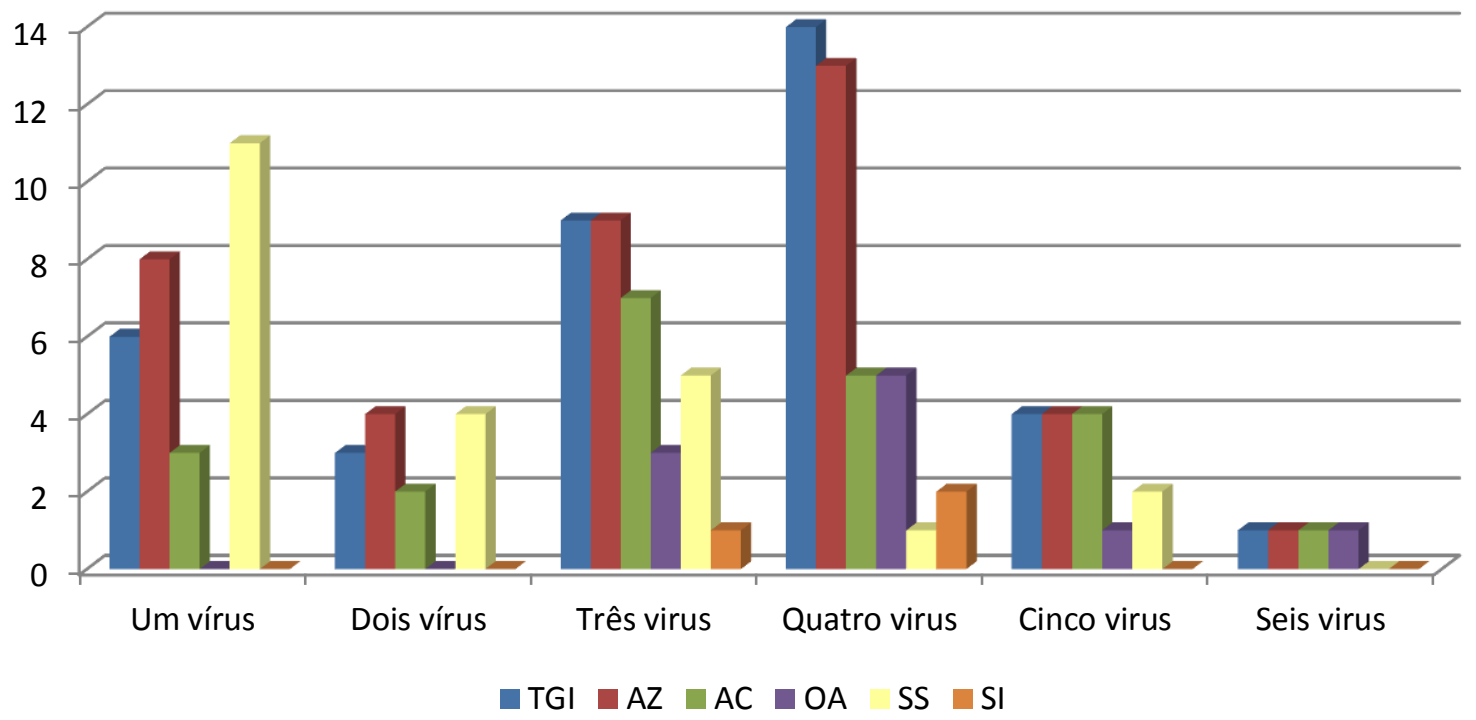

Gráfico 8 - Frequência do tipo de sinal clínico relatado e o número de vírus detectados por amostra 


\section{DISCUSSÃO}

As funções digestivas e absortivas são essenciais ao crescimento, desenvolvimento e saúde do animal, sendo o intestino uma barreira física contra a entrada de patógenos e toxinas no organismo. A interação entre digestão, absorção, função imune do intestino e o controle genético desses processos é fundamental a saúde e produção animal (MITCHELL; MORETÓ, 2006).

Uma grande variedade de agentes infecciosos pode estar associada a casos de enterites em perus, mas pouco se sabe sobre o papel dos vírus envolvidos nas chamadas síndromes entéricas. Reynolds (2003), afirmou: "A patogênese de doenças virais entéricas é uma entidade complexa e que, a etiologia de uma doença entérica é igualmente complexa". Com essa frase, o autor expressa a multiplicidade de agentes que podem ser detectados no intestino de aves acometidas por enterites, bem como a interação destes agentes na patogênese das doenças entéricas.

Desde 1937, quando Pomeroy e Fenstermacher relataram o primeiro caso de enterite em perus, diversos estudos foram conduzidos na tentativa de se relacionar os quadros de enterites a um ou mais agente etiológico (SIEBURTH; JOHNSON, 1957; DESHMUKH et al., 1969; FUJISAKI; KAWAMURA; ANDERSON, 1969; HOFSTAD; ADAMS; FREY, 1969; ADAMS; HOFSTAD, 1971). Diversas ferramentas diagnósticas foram utilizadas para a detecção de agentes como Adenovírus, Astrovírus, Coronavírus, Enterovírus, Picornavírus, Reovírus, Rotavírus, sendo que alguns estudos foram de importância e serviram de referência para este trabalho (SAIF; SAIF; THEIL, 1985; DAY; SPACKMAN; PANTIN-JACKWOOD, 2007; PANTIN-JACKWOOD et al., 2008; JINDAL et al., 2010b). Estudos mais recentes vêm utilizando técnicas moleculares para a detecção viral, pois estas permitem detectar baixas concentrações virais (JINDAL et al., 2010b) quando comparadas aos métodos tradicionais como a microscopia eletrônica (ME), pois além de serem mais sensíveis e específicas do que a ME, possibilitam a caracterização viral através do sequenciamento do material genético detectado.

No Brasil, não há conhecimento dos diferentes vírus envolvidos nos quadros de enterites que ocorrem em perus, bem como sua presença no intestino de aves saudáveis. Dessa forma, foi fundamental a realização de uma triagem com o objetivo de se conhecer os agentes virais encontrados no intestino de lotes de perus 
apresentando ou não sinais de doença entérica. Os resultados do estudo mostraram que a PCR é uma metodologia para o diagnóstico de vírus entéricos nos perus, havendo-se obtido as bandas no peso molecular relatado nas referências internacionais (HESS; RAUE; HAFEZ, 1999; KOCI; SEAL; SCHULTZ-CHERRY, 2000a; CAVANAGH et al., 2002; ALVARADO et al., 2007; DAY; SPACKMAN; PANTIN-JACKWOOD, 2007; PANTIN-JACKWOOD et al., 2008).

A produção de perus no país está distribuída geograficamente em três principais regiões produtoras, a região Sul (Paraná, Santa Catarina e Rio Grande do Sul) na qual o Paraná destaca-se como maior Estado produtor de perus do país com $46 \%$ da produção nacional, a região Sudeste (Minas Gerais) e a região CentroOeste (Goiás). Estes Estados respondem por 100\% da produção nacional de perus demonstrando sua importância na produção avícola no Brasil (RELATÓRIO ANUAL DA UNIÃO BRASILEIRA DE AVICULTURA, 2009), o que reflete a distribuição das amostras avaliadas neste estudo.

Observou-se neste estudo um elevado número de amostras positivas para pelo menos um agente viral estudado (93,4\%), e apenas 6,6\% de amostras negativas, o que concorda com o estudo de prevalência de vírus entéricos realizado nos Estados Unidos, em 1985, por Saif, Saif e Theil que demonstraram por ME e PAGE que $93 \%$ das amostras intestinais estudadas eram positivas. Outros estudos empregando PCR mostraram 100\% amostras positivas para pelo menos um vírus (PANTIN-JACKWOOD et al., 2008; JINDAL et al., 2010b).

Os sinais clínicos mais relatados nas fichas clínicas deste estudo foram os entéricos, como presença de diarreia, fezes com muco e/ou sanguinolentas; e as alterações zootécnicas, como redução no ganho de peso, diminuição do consumo de ração, presença de aves refugas e/ou mortalidade nos lotes estudados. Estes relatos condizem com os sinais clínicos presentes nas síndromes entéricas descritas por diversos autores acometendo perus (POMEROY; SIEBURTH, 1953; SIEBURTH; JOHNSON, 1957; GROSS; MOORE, 1967; YU et al., 2000; CARVER et al., 2001; CAVANAGH, 2005).

Os dados demonstraram a ocorrência de vírus entéricos ao longo de todo o processo produtivo, ou seja, desde a primeira semana até o abate. O estudo de Jindal et al. (2010a) foi conduzidos até a 9a semana, e o de Pantin-Jackwood et al. (2007) até a $12^{-}$semana de idade, e estes demonstraram a presença de vírus no intestino das aves nas idades estudadas. 
Na fase inicial de criação (1 a 4 semanas) houve a detecção de mais de um vírus por amostra, sendo encontrada média de 3,20 vírus por amostra e todos os lotes apresentaram sinais clínicos, enquanto que na fase de terminação (5 a 18 semanas), se encontrou a média de 2,41 vírus por amostra e menos de metade dos lotes apresentou sinais clínicos (25 amostras do total de 56 da fase de terminação).

O número de vírus detectados em cada fase de criação e a frequência de detecção de cada agente encontrado neste estudo reflete uma maior suscetibilidade dos perus aos vírus entéricos nas primeiras semanas de vida, quando o epitélio intestinal ainda está imaturo, como já foi demonstrado por diversos autores (REYNOLDS; SAIF; THEIL, 1987a; ISMAIL; TANG; SAIF, 2003; SAIF, 2008; JINDAL et al., 2009). No período inicial o intestino da ave passa um período de maturação intestinal onde há a adaptação do epitélio e desenvolvimento de imunidade local e da flora bacteriana comensal. Essa maturação ocorre porque, o organismo da ave que antes digeria e absorvia somente lipídeos e proteínas (componentes da gema), passa a receber rações comerciais ricas em carboidratos, lipídeos e também proteínas (UNI, 2006), ocorrendo acelerado crescimento no tamanho e número das vilosidades intestinais, sendo que em frangos, o duodeno termina seu desenvolvimento aos sete dias de idade, e o jejuno e íleo somente aos 14 dias (UNI; NOY; SKLAN, 1995, 1999). Ao nível celular observou-se que os enterócitos da ave, no momento da eclosão, são todos proliferativos ao longo da vilosidade, reduzindo para $50 \%$ aos dois ou três dias de vida e continua diminuindo mais lentamente até que sua concentração seja restrita à região das criptas (UNI; PLATIN; SKLAN, 1998).

Verificou-se que em lotes na fase de terminação, houve menor detecção dos vírus estudados, sendo exceção o Reovírus e o TAV, e houve 28 amostras sem relatos de sinais clínicos.

Os resultados encontrados mostraram que $81,6 \%$ das amostras foram positivas para Astrovírus (TAstV-1, TAstV-2 e/ou ANV), semelhante ao que PantinJackwood et al. observaram nos Estados Unidos (89,5\%) em 2007. No ano de 2008, Pantin-Jackwood et al. determinaram 100\% de positividade para Astrovírus em amostras de perus comerciais. No entanto, quanto ao tipo de Astrovírus detectado com maior frequência há diferença entre os resultados deste estudo e aqueles da literatura. Neste estudo, o TAstV-1 foi encontrado com maior frequência, ou seja, em $64,5 \%$ das amostras e o TAstV-2 em $44,7 \%$ destas, enquanto no estudo de Pantin- 
Jackwood et al. (2008) TAstV-1foi detectado em 28,1\% das amostras, e o TAstV-2 em $71,9 \%$, sendo este agente o mais detectado também nos estudos conduzidos por Jindal et al. (2010b).

O ANV foi observado em $35,5 \%$ das amostras, o que confirma os dados da literatura sobre a presença desse agente em lotes de perus, pois que em granjas dos Estados Unidos este agente foi relatado em 12,5\% das amostras (PANTINJACKWOOD et al., 2008). Embora a presença de TAstV-2 tenha sido relacionada a quadros de PEMS em perus (REYNOLDS, SAIF, THEIL, 1987b; BARNES GUY, 1997; ISMAIL, TANG; SAIF, 2003), o papel de TAstV-1 ou ANV no desenvolvimento de enterites em perus ainda não é conhecido. Neste estudo, os Astrovírus foram os vírus mais prevalentes entre aqueles estudados e isto está de acordo com outros autores (SAIF; SAIF; THEIL, 1985; REINOLDS; SAIF, 1986; REINOLDS; SAIF; THEIL, 1987a; PANTIN-JACKWOOD et al., 2008).

Neste estudo, os Astrovírus (TAstV-1, TAstV-2 ou ANV) foram detectados isoladamente em apenas 9 amostras, sendo que em 53 amostras foram detectados em associação com outros agentes, ou ainda em associação com os diferentes tipos de Astrovírus (36 em 76 amostras ou 47,4\%), ou seja, estas associações foram mais freqüentes do que as $27,9 \%$ encontradas por Pantin-Jackwood et al. (2008).

A maioria das amostras apresentava a presença de mais de um vírus $(69,7 \%)$ e se verificou que Astrovírus estiveram presentes em todas as amostras onde ocorreram associação de vírus. A elevada frequência de associação de vírus entéricos está de acordo com a literatura (SAIF; SAIF; THEIL, 1985; PANTINJACKWOOD et al., 2008; JINDAL et al., 2009; JINDAL et al., 2010b) e demonstra a circulação destes vírus nos lotes de perus nas regiões estudadas.

O TCoV foi detectado neste estudo em 55,3\% das amostras, portanto em um índice menor do que aqueles descritos por Villarreal et al. (2006) e Silva et al. (2009) que detectaram, respectivamente, em $80 \%$ e $78,9 \%$ das amostras. No entanto, estes autores estudaram amostras provenientes de aves acometidas por enterites, especialmente PEMS, enquanto que neste estudo foram estudadas amostras obtidas de de aves com ou sem sinais clínicos. Outros autores também relataram a presença do TCoV em aves acometidas por PEMS (KOCI; SEAL; SCHULTZCHERRY, 2000b; VILLARREAL et al., 2006; SILVA et al., 2009). Nos Estados Unidos, Pantin-Jackwood et al. $(2007,2008)$ não detectaram o TCoV em lotes de 
aves sem sinais clínicos, assim como Jindal et al. (2010b) não detectaram o vírus em aves acometidas pela síndrome da enterite dos perus (PES).

TCoV foi detectado em associação com um ou mais vírus em 39 amostras, sendo que nestas havia a presença de Astrovírus. O vírus foi observado isoladamente em apenas três amostras. Yu et al. (2000) demonstraram que a inoculação concomitante de Astrovírus e TCoV induzia a uma maior intensidade de sinais clínicos e elevada mortalidade quando comparado com as infecções individuais realizadas com cada agente. Nos casos de PEMS, a infecção concomitante por esses dois agentes pode ser uma causa da mortalidade elevada observada nos lotes acometidos por essa síndrome (YU et al., 2000; BARNES; GUY, 2003).

A presença de TAstV-2 e TCoV nas amostras com sinais clínicos deste estudo demonstram a importância destes vírus no desenvolvimento de enterites como a PEMS, no entanto o TCoV também foi detectado em $28,6 \%$ de amostras sem sinais clínicos, este resultado não foi encontrado por Pantin-Jackwood et al. (2008) e Jindal et al. (2010a). Foi demonstrado que a imunidade adaptativa para este vírus com secreção de IgA está presente nas aves por até seis (06) meses (POMEROY et al., 1975). Já Loa et al. (2002) observaram a presença de imunidade protetora ( $\lg A)$ por nove (09) semanas no intestino de aves inoculadas com TCoV aos 10 dias de idade. As amostras sem sinais clínicos (todas em fase de terminação) onde a detecção de TAstV-2 e TCoV foi menor, poderia ser consequência da presença de Imunoglobulinas A $(\lg A)$ específicas contra esse agente secretadas no intestino de aves, o que poderia impedir o desenvolvimento de infecção.

Astrovírus (TAstV-1, TAstV-2 e ANV) foram detectados em todas as fases de criação, desde a inicial até a terminação. Pantin-Jackwood et al. (2007) e Jindal et al. (2010a) demonstraram a presença intermitente de astrovírus até a $12^{\underline{a}}$ semana de idade. O TCoV foi detectado nas quatro (04) primeiras semanas de idade em 85\% das amostras, enquanto que na fase de terminação foi detectado em 44,6\% dos lotes. Este vírus pode ser encontrado em aves de todas as idades (GUY, 1998), sendo mais comum o desenvolvimento de sinais clínicos em perus nas primeiras semanas de vida (YU et al., 2000; CARVER et al., 2001; ISMAIL; TANG; SAIF, 2003). O sistema imunológico da ave também passa por um período de adaptação logo após a eclosão. Beal et al. (2006) sugeriram que as aves seriam capazes de se 
defender de patógenos entéricos somente quando o tecido linfoide associado ao intestino (GALT) estivesse completamente desenvolvido. As placas de Peyer, um dos componentes do GALT são visualizadas no intestino das aves somente a partir de duas semanas de vida, alcançando o número máximo de cinco placas nas 16 semanas de idade (BEFUS et al., 1980). Além disso, apesar da Bursa de Fabricius (órgão linfoide primário) desenvolver linfócitos $B$ no final do estágio embrionário e nos primeiros dias de vida da ave (BEAL et al., 2006), estudo experimental com antígeno administrado por via oral demonstrou que este induzia uma resposta imune adaptativa, através da produção de anticorpos, a partir da segunda semana de vida (BAR-SHIRA; SKLAN; FRIEDMAN, 2003).

Além disso, no momento da eclosão, a lâmina própria contém pouco estroma e linfócitos, sendo que apenas aos 17 dias de vida da ave há um aumento do estroma, linfócitos, células mononucleares e eosinófilos (YASON; SUMMERS; SCHAT, 1987). Vervelde e Jeurissen, 1993 demonstraram que o número de linfócitos no epitélio intestinal aumentava com a idade conforme seriam liberados pelo timo, sendo que a maior concentração de linfócitos ocorria oito (08) semanas após a eclosão. A dificuldade de desenvolvimento de uma resposta imune, tanto inata como adaptativa, nas primeiras semanas de vida da ave poderia ter contribuído para que ocorresse uma maior infecção das aves e desenvolvimento de sinais clínicos na fase inicial de criação como ocorreu na detecção deste vírus.

Rotavírus foram detectados em $52,6 \%$ das amostras, este resultado corrobora com os de Pantin-Jackwood et al. (2008) que detectaram o vírus em 69,7\% das amostras de perus. No entanto, Jindal et al. (2010b) encontraram uma elevada positividade deste agente (93\%) em aves acometidas por PES, sugerindo que Rotavírus estivesse envolvido nesta síndrome. Rotavírus foram detectados com maior frequência nos lotes até a quarta semana de idade (55\%), no entanto, também foi encontrado em $51,8 \%$ dos lotes na fase de terminação, sendo detectado com alta frequência nos lotes com e sem sinais clínicos. Pantin-Jackwood et al. (2007) observaram que, apesar de uma menor frequência, o Rotavírus foi detectado em perus com mais de seis (06) semanas de idade, sem sinais clínicos, sugerindo que, como neste estudo, o período de infecção é maior do que até a sexta semana de idade como também foi relatado por outros autores (WOOLCOCK; SHIVAPRASAD, 2008; JINDAL et al., 2009). A sua detecção nas aves mais velhas e sem sinais clínicos pode ser consequência da presença de microbiota comensal no intestino 
das aves capazes de realizar uma proteção do intestino, assim, o vírus pode estar presente mas não ocorre o desenvolvimento da doença, no entanto, o mesmo não ocorre em aves logo após a eclosão que não apresentam microbiota local, possibilitando a entrada de patógenos (NURMI; RANTALA, 1973).

Dentre as 40 amostras positivas para Rotavírus em apenas seis o vírus foi detectado isoladamente, sendo que nas demais este foi observado em associação com outros agentes. Yason e Schat (1986) demonstraram que a inoculação experimental de Rotavírus propagados em células, que haviam sido isolados de aves acometidas por diarreia e mortalidade a campo, foi capaz de causar diarreia nas aves, mas não ocorreu um aumento de mortalidade, sugerindo que outros vírus poderiam estar associados a uma intensificação dos sinais clínicos.

Reynolds, Saif e Theil (1987b) sugerem que a associação entre Astrovírus e Rotavirus pode ter papel importante no desenvolvimento de enterites em perus devido a elevada positividade desses agentes nos lotes de aves doentes, sendo essa associação a mais frequente entre aquelas encontradas por alguns autores (REYNOLDS; SAIF; THEIL, 1987a; JINDAL et al., 2010a). Em nosso estudo ela foi a segunda mais encontrada (34 amostras), e foram observadas ainda 27 associações Astrovírus/TCoV/Rotavírus, sendo esta a mais frequente no Estado de Santa Catarina (9/43 amostras), onde houve a maior média de número de vírus encontrados (3,14 vírus), podendo-se sugerir um maior desafio na região do que em Goiás, onde a média foi de 1,73 vírus encontrados nas amostras. Neste Estado as amostras eram provenientes de lotes sem sinais clínicos e de aves na fase de terminação (5 a 18 semanas), o que explica o menor número médio de vírus detectados.

Não foi realizado um estudo temporal ao longo de alguns anos, mas a maior detecção viral observada nos meses de Outono e Inverno corrobora com os resultados de maior detecção de TCoV e Astrovírus relatada por Silva et al. (2009) como sendo maior nos meses de inverno em amostras da região Sudeste brasileira. Os autores sugerem que a baixa humidade do ar, que produz maior quantidade de partículas em suspensão, pode permitir maior dispersão dos vírus presentes nas fezes na cama das aves.

O pequeno número de amostras recebidas de Minais Gerais (7) não possibilitou a identificação de um padrão de associação mais encontrado na região. 
$\mathrm{Na}$ fase terminação houve a maior frequência de detecção de um único vírus por amostra $(26,8 \%)$, além de menor média de número de vírus por amostra, enquanto que na fase inicial foi observado maior número de vírus em associação por amostra e maior percentual de detecção de cada agente individualmente. Este comportamento pode estar associado à maturidade intestinal, que após a quarta semana de idade deveria ter atingido seu funcionamento completo, e onde, o revestimento de mucina (SMIRNOV; SKLAN; UNI, 2004; SMIRNOV et al., 2005), a presença de IgA (MUKIIBI-MUKA; JONES, 1999), as bactérias residentes (NURMl; RANTALA, 1976), e a atividade do sistema imune intestinal (BARSHIRA;FRIEDMAN, 2003), proporcionam não só uma barreira física como imunológica para garantir o equilíbrio intestinal, e evitar a aderência e invasão deste meio por agentes patogênicos.

Embora Reovírus tenham sido detectados nos Estados Unidos em 40\% e $45,5 \%$ das amostras estudadas, respectivamente, por Jindal et al. (2010b) e PantinJackwood et al. (2008), respectivamente, no presente estudo, somente $7,9 \%$ das amostras foram positivas. Nenhuma amostra apresentou o Reovírus sozinho e isto está de acordo com Pantin-Jackwood et al. (2008). Pantin-Jackwood et al. (2007) não detectaram Reovírus em nenhuma amostra estudada oriunda de aves sem sinais clínicos, e Jindal et al. (2010a) detectaram o vírus em percentual semelhante ao deste estudo $(10,4 \%)$ no entanto em aves sem sinais clínicos. No entanto, Jindal et al. (2010b) observaram a alta positividade para este agente em lotes de aves com sinais de PES e Pantin-Jackwood et al. (2008) de amostras aleatórias recebidas do campo em diferentes localidade dos Estados Unidos e sem informação sobre o estado de saúde das aves.

Em 1969, Reovírus foram isolados e inoculados em aves que tiveram sinais clínicos da doença de Bluecomb, hoje denominada de PEMS, presumindo que este vírus seria um dos causadores da enfermidade (DESHMUKH et al., 1969; WOOLEY; GRATZEK, 1969). O método de observação até então utilizado era a ME, e como foi demonstrado por Jindal et al. (2010b) esse método não era sensível como o RTPCR na detecção de vírus entéricos, e identificava grande número de amostras como falsas negativas para determinados vírus. Dessa forma, pode-se levantar a hipótese de que na década de 60, as amostras continham apenas Reovírus, poderiam conter outros agentes que contribuiriam para o desenvolvimento de PEMS. Assim, ainda não foi demonstrada a participação do Reovírus como um agente 
primário da doença ou, quando associado a outros vírus, permitiria a intensificação dos sinais clínicos da enfermidade.

Todas as amostras com sinais clínicos tiveram a presença de pelo menos um dos vírus estudados, havendo maior concentração de amostras com a detecção de três a quatro vírus. Os resultados também demonstraram a presença de vírus em lotes de aves sem sinais clínicos e concordam com os dados de literatura (REYNOLDS; SAIF; THEIL, 1987a; PANTIN-JACKWOOD et al., 2008; JINDAL et al., 2010a). Nas amostras provenientes de lotes sem sinais clínicos houve menor número de vírus detectados em associação, sendo que em 11 delas, de um total de 23 amostras positivas, houve a detecção de um agente por amostra.

Esses dados corroboram com os resultados de Jindal et al. (2010a) que observaram $61,1 \%$ de amostras positivas em lotes de perus sem sinais clínicos, e destas amostras 59,3\% tiveram a detecção de um agente, sendo que a maioria apresentava TAstV-2 ou rotavírus isoladamente. Em outro estudo, utilizando aves acometidas por PES, Jindal et al. (2010b) verificaram que 81,4\% das amostras estudadas foram positivas para dois (02) ou três (03) vírus. Embora Jindal et al. (2010a, b) tenham estudado somente TAstV-2, TCoV, Reovírus e Rotavírus, os resultados sugerem que a associação de diferentes agentes pode ser relevante no desenvolvimento e maior severidade dos sinais clínicos nas aves (SAIF; SAIF; THEIL, 1985; JINDAL et al., 2010a). Além disso, em seis amostras foram encontrados cinco vírus e em duas, seis vírus, sugerindo que essa multiplicidade de agentes encontrados em nosso estudo pode provocar um efeito aditivo nos sinais clínicos, como citado por Jindal et al. (2009).

O TAstV-1 foi o mais detectado tanto em aves com e sem sinais clínicos e ainda nas diferentes fases de criação, sugerindo uma persistência do agente nas diferentes fases e que, individualmente, não é capaz de causar sinais clínicos nas aves, podendo agir como agente secundário na infecção. A presença de Reovírus nas amostras sem sinais clínicos confirmam os resultados de Jindal et al. (2010a). Além disso, Reynolds, Saif e Theil (1987a) também verificaram a presença de Astrovirus e Rotavírus tanto em aves com sinais clínicos como em aves normais, os autores usaram microscopia eletrônica na detecção viral, não sendo possível determinar o tipo de Astrovírus observado. Mais tarde, Jindal et al. (2010a) verificou que a associação única de Rotavírus e TAstV-2 não foi capaz de causar sinais clínicos em diferentes idades, sendo necessária a ocorrência de um agente iniciando 
a infecção. As amostras foram coletadas somente uma vez em cada lote, não sendo possível determinar se o organismo das aves sem sinais clínicos já haviam controlado a infecção e estavam eliminando o vírus ou se, recentemente, haviam sido infectadas e ainda não apresentavam sinais clínicos. Outra hipótese é a que a presença de anticorpos específicos contra os vírus pode prevenir o aparecimento de sinais clínicos. Mukiibi-Muka e Jones (1999) observaram que aves de uma (01) semana de idade inoculadas com Reovírus por via oral não foram capazes de produzir quantidade significativa de $\lg A$, já aves de três (03) semanas de idade tiveram aumento de $\lg A$ específica no intestino. No entanto, estudos experimentais onde se relaciona proteção contra patógenos e idade da ave são escassos.

TCoV e Rotavírus replicam-se na porção apical do vilo intestinal, causando a destruição das vilosidades intestinais, e, como consequência, ocorre má-absorção de nutrientes e diarreia (NAQI; PANIGRAPHY; HALL, 1972; YASON; SCHAT, 1986). Astrovírus se replicam na porção basal do vilo e mais raramente nas criptas, e são capazes de causar diarreia osmótica (BEHLING-KELLY et al., 2002; REYNOLDS; SCHULTZ-CHERRY, 2003). Além disso, há relatos da ocorrência de depressão de órgãos linfóides (timo, Bursa de Fabricius e baço) em aves acometidas por infecções virais entéricas (TEIXEIRA et al., 2007; JINDAL et al., 2009). Dessa forma, as alterações podem permitir a entrada de patógenos secundários presentes no meio ambiente e ainda comprometer respostas vacinais devido ao comprometimento imune.

As associações de diferentes agentes na mesma amostra corroboram com os relatos de outros autores que ao estudar alguns destes vírus puderam observar a sua associação e ainda a presença de algumas bactérias. Adams e Hofstad (1972) verificaram que Streptococcus sp aumentaram a severidade de enterites em perus acometidos pela doença de Bluecomb. Além disso, a associação entre astrovírus e TCoV pode predispor o organismo da ave ao surgimento de infecções oportunistas por outros patógenos, como E. coli e Salmonella spp (BARNES; GUY, 1999; GUY et al., 2000; QURESHI; YU; SAIF, 2000; BARNES; GUY, 2003). No entanto, ainda não foi demonstrado se as bactérias exerceriam algum papel primário nas infecções entéricas virais ou apenas seriam agentes secundários que prolongariam e agravariam os problemas entéricos (JINDAL et al., 2009). Segundo Beal et al. (2006) alterações no perfil dos linfócitos presentes na lâmina própria e ao longo do epitélio, 
que podem ser influenciadas pela idade, genótipo, estado de saúde e dieta da ave, podem predispor o organismo da ave ao desenvolvimento de infecções secundárias.

Adenovírus do grupo 1 foram detectados em 5,3\% das amostras, no entanto não se sabe o papel desses agentes em enterites, e não foram detectados em amostras intestinais de perus nos Estados Unidos por Pantin-Jackwood et al. (2007). Os Adenovírus do grupo 2 (HEV) não foram detectados nas amostras de perus estudadas, este resultado corrobora os encontrados por Pantin-Jackwood et al. (2008). O número de amostras positivas para TAV foi um pouco maior na fase de terminação, no entanto o pequeno número de amostras positivas dificultou a análise desses dados, assim não foi possível relacionar à idade de maior ocorrência, ou à presença de sinais clínicos.

O período de maturação intestinal pode ter implicações diretas na resistência a infecções entéricas já que há menor barreira física contra a entrada de patógenos (UNI, 2006). Além disso, problemas no manejo, condições nutricionais, composição da dieta e flora intestinal podem afetar a dinâmica da mucina. Um atraso na primeira alimentação da ave pode resultar em demora na maturação do epitélio intestinal como foi demonstrado por Yamauchi, Kamisoyama e Isshiki (1996) e Geyra, Uni e Sklan (2001) onde menor comprimento das vilosidades intestinais, menor tamanho de cripta, menos criptas por vilo e menor taxa migração de enterócitos para o ápice do vilo ocorreu em aves que sofreram 24-48 horas de atraso na primeira alimentação. Uni, Smirnov e Sklan (2003) relataram menor numero de enterócitos e aumento de densidade nas células caliciformes no jejuno e íleo, que pode ser devido a um aumento da síntese ou diminuição da secreção da mucina, que se acumula em seu interior da célula já que o epitélio está imaturo. Além disso, interferência na síntese proteica, como em casos de problemas no fornecimento de alimento para a ave ou fatores que levem à má-nutrição pode induzir uma alteração na constituição da camada de mucina (SHARMA et al., 1997; LANGHOUT et al., 1999). Se essa mucina não é secretada há comprometimento da proteção intestinal mecânica e por parte da microbiota comensal que usa essa estrutura como substrato para a fermentação, como o Lactobacillus spp. (GUSILS et al., 2003).

As adaptações que o organismo da ave sofre no período inicial de criação podem estar relacionadas na maior suscetibilidade aos vírus entéricos demonstrada neste trabalho, demonstrando a necessidade de controle das medidas de biossegurança, manejo e nutrição a fim de se evitar a entrada de patógenos 
intestinais. Em ambiente experimental, Pantin-Jackwood et al. (2007) observaram aumento de peso de 0,23 $\mathrm{Kg}$ em aves de cinco (05) semanas de idade e melhor conversão alimentar quando comparado às aves em criações comerciais.

Além disso, os sinais clínicos podem ser discretos e algumas vezes pouco visíveis no ambiente de produção, e que, apesar de não causar aumento de mortalidade, podem induzir perdas produtivas significativas (JINDAL et al., 2010a). A ausência de informações sobre a presença de sinais clínicos, como diarreia, pode ter como uma possível causa aves com diarreia e fezes de consistência muito líquida, que podem não apresentar emplastramento de cloaca, sendo excretadas sem adesão nas penas e rapidamente absorvidas quando em contato com a cama (TRAMPEL et al., 1983).

A multiplicidade de agentes que afetam o intestino das aves dificulta a compreensão do papel exato de cada agente no desenvolvimento de enterites. Diversos estudos têm focado a descrição desses agentes, principalmente utilizandose ferramentas de biologia molecular (VILLAREAL et al., 2006; PANTINJACKWOOD et al., 2007; SILVA et al., 2008; JINDAL et al., 2010a). O uso da metagenômica é o método mais recentemente divulgado capaz de mostrar todos os agentes que podem ser encontrados no ambiente entérico, através de sequenciamento global do material genético presente (DAY et al., 2010). No entanto, ainda são necessários estudos experimentais para se entender o mecanismo de desenvolvimento e intensificação dos sinais clínicos pelos vírus em particular ou isoladamente nas denominadas síndromes entéricas. 


\section{CONCLUSÕES}

D Os vírus entéricos TAstV-1, TCoV, Rotavírus e TAstV-2 foram os mais detectados.

$>$ O estudo demonstrou que a maioria dos vírus detectados estavam associados.

> As associações de Astrovírus e TCoV; e de Astrovírus e Rotavírus foram as mais encontradas neste estudo.

> As aves em fase inicial de criação (1 a 4 semanas) mostraram-se mais suscetíveis a infecção viral ou enterite.

> Independente da idade das aves observou-se a detecção de vírus entéricos.

> Reovírus e TAV foram detectados com baixa frequência nas amostras e sempre estavam associados a outros vírus.

> TAstV-1 e TCoV foram os vírus mais frequentes nas amostras provenientes de lotes com sinais clínicos.

$>$ HEV não foi detectado em nenhuma amostra estudada. 


\section{REFERÊNCIAS}

ADAIR, B. M.; FITZGERALD, S. D. Group I adenovirus infections. In: SAIF, Y. M.; BARNES, H. J.; GLISSON, J. R.; FADLY, A. M.; MCDOUGALD, L. R.; SWAYNE, D. E. Diseases of poultry. 12th ed. Ames: lowa State University Press, 2008. p. 252266.

ADAMS, N. R.; HOFSTAD, M. S. Isolation of transmissible enteritis agent of turkeys in avian embryos. Avian Diseases, v. 15, p. 426-433, 1971.

ADAMS, N. R.; HOFSTAD, M. S. Transmissible enteritis infection in germfree and monocontaminated turkey poults. American Journal of Veterinary Research, v. 33, p. 1001-1005, 1972.

ALFIERI, A. F.; RESENDE, M.; RESENDE, J. S.; ALFIERI, A. Atypical rotavirus infections among broiler chickens in Brazil. Arquivos Brasileiros de Medicina Veterinaria e Zootecnia, v. 41, p. 81-82, 1989.

ALVARADO, I. R.; VILLEGAS, P.; El-ATTRACHE, J.; JENSEN, E.; ROSALES, G.; PEROZO, F.; PURVIS, L. B. Genetic characterization, pathogenicity, and protection studies with Avian Adenovirus isolate associated with inclusion body hepatitis. Avian Diseases, v. 51, p. 27-32, 2007.

ANDRAL, B.; TOQUIN, D. Observations et isolements de pseudopicornavirus a partir de dindonneaux malades. Avian Pathology, v. 13, p. 377-388, 1984.

BAR-SHIRA; E.; FRIEDMAN, A. Ontogeny of gut assocated immune competence in the chick. Israel Journal of Veterinary Medicine, v.60, p. 42-50, 2005.

BAR-SHIRA, E.; SKLAN, D.; FRIEDMAN, A. Establishment of immune competence in the avian GALT during the immediate post-hatch period. Developmental and Comparative Immunology, v. 27, p. 147-157, 2003.

BARNES, H. J. Viral enteric infections. In: CALNEK, B. W.; BARNES, H. J.; BEARD, C. W.; MCDOUGALD, L. R.; SAIF, Y. F. Diseases of poultry. 10th ed. Ames: lowa State University Press, 1997. p. 685-686.

BARNES, H. J.; GUY, J. S. Poult enteritis-mortality syndrome ("spiking mortality") of turkeys. In: CALNEK, B. W.; BARNES, H. J.; BEARD, C. W.; MCDOUGALD, L. R.; 
SAIF, Y. F. Diseases of poultry. 10th ed. Ames: lowa State University Press, 1997. p. 1025-1031.

BARNES, H. J.; GUY, J. S. Clinicopathologic findings in turkeys with severe form of poult enteritis mortality syndrome. Journal of the American Veterinary Medical Association, v. 215, p. 1675, 1999.

BARNES, H. J.; GUY, J. S. Poult enteritis-mortality syndrome. In: SAIF, Y. M.; BARNES, H. J.; GLISSON, J. R.; FADLY, A. M.; MCDOUGALD, L. R.; SWAYNE, D. E. Diseases of poultry. 11th ed. Ames: lowa State University Press, 2003. p. 320326.

BEAL, R. K.; POWERS, C.; DAVISON, T. F.; SMITH, A. L. Immunological development for the avian gut. In: PERRY, G. C. Avian gut function in health and disease. Wallingford: CABI, 2006. p. 85-103.

BEFUS, A. D.; JOHNSTON, N.; LESLIE, G. A.; BIENENSTOCK, J. Gut-associated lymphoid tissue in the chicken. I. Morphology, ontogeny, and some functional characteristics of Peyer's patches. Journal of Immunology, v. 125, p. 2626-2632, 1980.

BEHLING-KELLY, E.; SCHULTZ-CHERRY, S.; KOCI, M.; KELLEY, L.; LARSEN, D.; BROWN, C. Localization of astrovirus in experimentally infected turkeys as determined by in situ hybridization. Veterinary Pathology, v. 39, p. 595-598, 2002.

BERGELAND, M. E.; MCADARAGH, J. P.; STOTZ, I. Rotaviral enteritis in turkey poults. In: WESTERN POULTRY DISEASE CONFERENCE, 26.; POULTRY HEALTH SYMPOSIUM, 11., 1977, Davis. Proceedings...Davis: University of California, 1977. p. 129-130.

BLALOCK, H. G.; SIMMONS, D. G.; MUSE, K. E.; GRAY, J. G.; DERIEUX, W. T. Adenovirus respiratory infection in turkey poults. Avian Diseases, v. 19, p. 707-716, 1975.

BUNGER, A. N. D.; CHACÓN, J. L.; JONES, R. C.; FERREIRA, A. J. P. Detection and molecular characterization of gene 3 and 5 of turkey coronavirus from turkeys with severe enteritis in Brazil. Avian Diseases, v. 53, p. 356-362, 2009.

CARLSON, H. C.; AL-SHEIKHLY, F.; PETTIT, J. R.; SEAWRIGHT, G. L. Virus particles in spleen and intestines of turkeys with hemorrhagic enteritis. Avian Diseases, v. 18, p. 67-73, 1974. 
CARVER, D. K.; VAILLANCOURT, J. P.; STRINGHAM M.; GUY, J. S.; BARNES, H. J. Mortality patterns associated with poult enteritis mortality syndrome (PEMS) and coronaviral enteritis in turkey flocks raised in PEMS-affected regions. Avian

Diseases, v. 45, p. 985-991, 2001.

CASTRO, A. E.; MOORE, J.; HAMMAMI, S.; MANALAC, R. B.; CHIN, R. P. Direct isolation of rotaviruses from turkeys in embryonating chicken eggs. Veterinary Record, v. 130, p. 379-380, 1992.

CAVANAGH, D. Coronaviruses in poultry and other birds. Avian Pathology, v. 34, p. 439-448, 2005.

CAVANAGH, D.; MAWDITT, K.; WELCHMAN, D. B.; BRITTON, P.; GOUGH, R. E. Coronavíruses from pheasants (Phasianus colchicus) are genetically closely related to Coronavíruses of domestic fowl (Infectious Bronquitis Virus) and turkeys. Avian Pathology, v. 31, p. 81-93, 2002.

CHAPPELL, J. D.; DUCAN, R.; MERTENS, P. P. C.; DERMODY, T. S. Orthoreovirus. In: FAUQUET; C. M.; MAYO, M. A.; MANILOFF, J.; DESSELBERGER, U.; BALL, L. A. Virus taxonomy: eighth report of the international comittee on the taxonomy of viruses. San Diego: Elsevier Academic Press, 2005. p. 464-474.

$\mathrm{CHO}, \mathrm{B}$. R. An adenovirus from a turkey pathogenic to both chicks and turkey poults. Avian Diseases, v. 20, p. 714-723, 1976.

CONNOR, T. J.; MCNEILLY, F.; MCFERRAN, J. B.; MCNULTY, M. S. A survey of avian sera from northern Ireland for antibody to avian nephritis virus. Avian

Pathology, v. 16, p. 15-20, 1987.

COWEN, B. S. Chicken embryo propagation of type I avian adenoviruses. Avian Diseases, v. 32, p. 347-352, 1988.

DAVISON, A. J.; BENKO, M.; HARRACH, B. Genetic content and evolution of adenoviruses. Journal of General Virology, v. 84, n. 11, p. 2895-2908, 2003.

DAWSON, G. J.; ORSI, L. N.; YATES, V. J.; CHANG, P. W.; PRONOVOST, A. D. An Enzyme-linked immunosorbent assay for detection of antibodies to avian adenovirus and avian adenovirus-associated virus in chickens. Avian Diseases, v. 24, p. 393402, 1980. 
DAY, J. M.; BALLARD, L. L.; DUKE, M. V.; SCHEFFLER, B. E.; ZSAK, L. Metagenomic analysis of the turkey gut RNA virus community. Virology Journal, v. 7, p. 313-320, 2010.

DAY, J. M.; SPACKMAN, E.; PANTIN-JACKWOOD, M. A multiplex RT-PCR test for the differential identification of turkey astrovirus type 1, turkey astrovirus type 2, chicken astrovirus, avian nephritis virus, and rotavirus. Avian Diseases, v. 51, p. 681-684, 2007.

DEA, S.; GARZON, S.; TIJSSEN, P. Isolation and trypsin-enhanced propagation of turkey enteric (bluecomb) coronaviruses in a continuous human rectal adenocarcinoma cell line. American Journal of Veterinary Research, v. 50, p. 1310-1318, 1989.

DEA, S.; MARSOLAIS, G.; BEAUBIEN, J.; RUPPANNER, R. Coronaviruses associated with outbreaks of transmissible enteritis of turkeys in Quebec: Hemagglutination properties and cell cultivation. Avian Diseases, v. 30, p. 319-320, 1986.

DEA, S.; TIJSSEN, P. Detection of turkey enteric coronavirus by enzyme-linked immunosorbent assay and differentiation from other coronaviruses. American Journal of Veterinary Research, v. 50, p. 226-231, 1989.

DESHMUKH, D. R.; LARSEN, C. T.; DUTTA, S. K.; POMEROY, B. S. Characterization of pathogenic filtrate and viruses isolated from turkeys with bluecomb. American Journal of Veterinary Research, v. 30, p. 1019-1025, 1969.

DESHMUKH, D. R.; LARSEN, C. T.; POMEROY, B. S. Survival of bluecomb agent in embryonating turkey eggs and cell cultures. American Journal of Veterinary Research, v. 34, p. 673-675, 1973.

DEVITT, C. M.; REYNOLDS, D. L. Characterization of a group D rotavirus. Avian Diseases, v. 37, p. 749-755, 1993.

DOMERMUTH, C. H.; GROSS, W. B. Hemorrhagic enteritis of turkeys. Antiserum: Efficacy, preparations, and use. Avian Diseases, v. 19, p. 657-665, 1975.

DOMERMUTH, C. H.; GROSS, W. B.; DOUGLASS, C. S.; DUBOSE, R. T.; HARRIS, J. R.; DAVIS, R. B. Vaccination for hemorrhagic enteritis of turkeys. Avian Diseases, v. 21, p. 557-565, 1977. 
DOMERMUTH, C. H.; GROSS, W. B.; DUBOSE, R. T. Microimmunodiffusion test for hemorrhagic enteritis of turkeys. Avian Diseases, v. 17, p. 439-444, 1973.

DOMERMUTH, C. H.; GROSS, W. B.; DUBOSE, R. T.; DOUGLASS, C. S.; REUBUSH JR., C. B. Agar gel diffusion precipitin test for hemorrhagic enteritis of turkeys. Avian Diseases, v. 16, p. 852-857, 1972.

DOMERMUTH, C. H.; GROSS, W. B.; DUBOSE, R. T.; MALLINSON, E. T. Experimental reproduction and antibody inhibition of marble spleen disease of pheasant. Journal of Wildlife Diseases, v. 11, p. 338-342, 1975.

DUKE, G. E.; DZIUK, H. E.; EVANSON, O. A. Fluxes of ions, glucose, and water in isolated jejuna segments in normal and bluecomb diseased turkeys. Poultry Science, v. 48, p. 2114-2123, 1969.

DZIUK, H. E.; EVANSON, O. A.; LARSEN, C. T. Physiologic effects of fasting and bluecomb in turkeys. American Journal of Veterinary Research, v. 30, p. 10451056, 1969.

ESTES, M. K.; KAPIKIAN, A. Z. Rotaviruses. In: KNIPE, D. M.; HOWLEY, P. M. Fields virology. 5th ed. Baltimore: Lippincott Willians \& Wilkins, 2007. p. 1918-1974.

FUJISAKI, Y.; KAWAMURA, H.; ANDERSON, D. P. Reoviruses isolated from turkeys with bluecomb. American Journal of Veterinary Research, v. 30, p. 1035-1043, 1969.

GEYRA, A.; UNI, Z.; SKLAN, D. Enterocyte dynamics and mucosal development in the posthatch chick. Poultry Science, v. 80, p. 776-782, 2001.

GOMAA, M. H.; BARTA, J. R.; OJKIC, D.; YOO, D. Complete genomic sequence of turkey coronavirus. Virus Research, v. 135, p. 237-246, 2008.

GOODWIN, M.; DEKICH, M.; LATIMER, K.; FLETCHER, O. Quantitation of the intestinal D-xylose absorption in normal broilers with pale bird syndrome. Avian Diseases, v. 29, p. 630-639, 1984a.

GOODWIN, M.; NERSESSIAN, B.; BROWN, J.; FLETCHER, O. Gastrintestinal transit times in normal and reovirus-inoculated turkeys. Avian Diseases, v. 29, p. 920-928, 1984b. 
GOUVEA, V. S.; SCHNITZER, T. J. Polymorphism of the genomic RNAs among the avian reoviruses. Journal of General Virology, v. 61, p. 87-91, 1982a.

GOUVEA, V. S.; SCHNITZER, T. J. Polymorphism of the migration of doublestranded RNA genome segments of the avian reoviruses. Journal of Virology, v. 43, p. 465-471, 1982b.

GROSS, W. B.; MOORE, W. E. C. Hemorrhagic enteritis of turkeys. Avian Diseases, v. 11, p. 296-307, 1967.

GUSILS, C.; OPPEZZO, O.; PIZARRO, R.; GONZALEZ, S. Adhesion of probiotic Lactobacilli to chick intestinal mucus. Canadian Journal of Microbiology, v. 49, p. 472-478, 2003.

GUY, J. S. Turkey coronavirus is more closely related to avian bronchitis virus than to mammalian coronaviruses: a review. Avian Pathology, v. 29, p. 207-212, 2000.

GUY, J. S. Virus infections of the gastrointestinal tract of poultry. Poultry Science, v. 77, p. 1166-1175, 1998.

GUY, J. S.; LEVY, M. G.; LEY, D. H.; BARNES, H. J.; GERIG, T. M. Experimental reproduction of enteritis in bobwhite quail (colinus virginianus) with Cryptosporidium and reovirus. Avian Diseases, v. 31, p. 713-722, 1987.

GUY, J. S.; SMITH, L. G.; BRESLIN, J. J.; VAILLANCOURT, J. P.; BARNES, H. J. High mortality and growth depression experimentally produced in young turkeys by dual infection with enteropathogenic Escherichia coli and turkey coronavirus.

Avian Diseases, v. 44, p. 105-113, 2000.

HEGGEN-PEAY, C. L.; QURESHI, M. A.; EDENS, F. W.; SHERRY, B.; WAKENELL, P. S.; O'CONNELL, P. H.; CHAT, K. A. Isolation of Reovirus from poult enteritis and mortality syndrome and its pathogenicity in turkey poults. Avian Diseases, v. 46, p. 32-47, 2002.

HESS, M.; RAUE, R.; HAFEZ, H. M. PCR for specific detection of haemorrhagic enteritis virus of turkeys, an avian adenovirus. Journal of Virological Methods, $v$. 81, p. 199-203, 1999. 
HIERONYMUS, D. R. K.; VILLEGAS, P.; KLEVEN, S. H. Identification and serological differentiation of several reovirus strains isolated from chickens with suspected malabsorption syndrome. Avian Diseases, v. 27, p. 246-254, 1983.

HOFSTAD, M. S.; ADAMS, N.; FREY, M. L. Studies on a filtrable agent associated with infectious enteritis (bluecomb) of turkeys. Avian Diseases, v. 13, p. 386-393, 1969.

HOLMES, K. V.; LAI, M. M. C. Coronaviridae: The viruses and their replication. In: FIELDS, B. N.; KNIPE, D. M.; HAWLEY, P. M. Fields virology. 3rd ed. Philadelphia: Lippincott-Raven Publishers, 1996. p. 1075-1103.

IMADA, T.; YAMAGUCHI, S.; KAWAMURA, H. Pathogenicity for baby chicks of the G-4260 strain of the picornavirus "avian nephritis virus". Avian Diseases, v. 23, p. 582-588, 1979.

IMADA, T.; YAMAGUCHI, S.; MASE, M.; TSUKAMOTO, K.; KUBO, M.; MOROOKA, A. Avian nephritis virus (ANV) as a new member of the family Astroviridae and construction of infectious ANV cDNA. Journal of Virology, v. 74, n. 18, p. 84878493, 2000.

ISMAIL, M. M.; TANG, Y.; SAIF, Y. M. Pathogenicity of turkey coronavirus in turkeys and chickens. Avian Diseases, v. 47, p. 515-522, 2003.

ITO, H.; SUGIYAMA, M.; MASUBUCHI, K.; MORI, Y.; MINAMOTO, N. Complete nucleotide sequence of a group $A$ avian rotavirus genome and a comparison with its counterparts of mammalian rotaviruses. Virus Research, v. 75, p. 123-138, 2001.

JINDAL, N.; PATNAYAK, D. P.; CHANDER, Y.; ZIEGLER, A. F.; GOYAL, S. M. Detection and molecular characterization of enteric viruses in breeder turkeys. Avian Pathology, v. 39, p. 53-61, 2010a.

JINDAL, N.; PATNAYAK, D. P.; CHANDER, Y.; ZIEGLER, A. F.; GOYAL, S. M. Detection and molecular characterization of enteric viruses from poult enteritis syndrome in turkeys. Poultry Science, v. 89, p. 217-226, 2010 b.

JINDAL, N.; PATNAYAK, D. P.; ZIEGLER, A. F.; LAGO, A.; GOYAL, S. M. Experimental reproduction of poult enteritis syndrome: clinical findings, growth response, and microbiology. Poultry Science, v. 88, p. 949-958, 2008. 
JINDAL, N.; PATNAYAK, D. P.; ZIEGLER, A. F.; LAGO, A.; GOYAL, S. M. A retrospective study on poult enteritis syndrome in Minnesota. Avian Diseases, v. 53, p. 268-275, 2009.

KANG, S. Y.; NAGARAJA, K. V.; NEWMAN, J. A. Electropherotyping analysis of rotaviruses isolated from turkeys. Avian Diseases, v. 30, p. 794-801, 1986.

KAPCZYNSKI, D. R.; SELLERS, H. S.; SIMMONS, V.; SCHULTZ-CHERRY, S. Sequence analysis of the $S 3$ gene froma turkey reovirus. Virus Genes, v. 25, n. 1, p. 95-100, 2002.

KAWAMURA, H.; SHIMIZU, F.; MAEDA, M.; TSUBAHARA, H. Avian reovirus: Its properties and serological classification. National Institute of Animal Health Quarterly, v. 5, n. 3, p. 115-124, 1965.

KERR, K. M.; OLSON, N. O. Pathology of chickens experimentally inoculated or contact-infected with an arthritis-producing virus. Avian Diseases, v. 13, p. 729-745, 1969.

KOCI, M. D.; MOSER, L. A.; KELLEY, L. A.; LARSEN, D.; BROWN, C. C.; SCHULTZ-CHERRY, S. Astrovirus induces diarrhea in the absence of inflammation and cell death. Journal of Virology, v. 77, n. 21, p. 11798-11808, 2003.

KOCI, M. D.; SEAL, B. S.; SCHULTZ-CHERRY, S. Development of an RT-PCR diagnostic test for an avian astrovirus. Journal of Virological Methods, v. 90, p. 7983, 2000a.

KOCI, M. D.; SEAL, B. S.; SCHULTZ-CHERRY, S. Molecular characterization of an avian astrovirus. Journal of Virology, v. 74, n. 13, p. 6173-6177, $2000 \mathrm{~b}$.

LANGHOUT, D. J.; SCHUTTE, J. B.; VAN LEEUWEN, P. V.; WIEBENGA, J.;

TAMMINGA, S. Effect of dietary high-and low-methylated citrus pectin on the activity of the ileal microflora and morphology of the small intestinal wall of broiler chicks.

British Poultry Science, v. 40, p. 340-347, 1999.

LIU, H. J.; GIAMBRONE, J. J. In situ detection of reovirus in formalin-fixed, paraffinembedded chicken tissues using a digoxigenin-labeled cDNA probe. Avian

Diseases, v. 41, p. 447-451, 1997. 
LIU, H. J.; GIAMBRONE, J. J.; NIELSEN, B. L. Molecular characterization of avian reoviruses using nested PCR and nucleotide sequence analysis. Journal of Virological Methods, v. 65, p. 159-167, 1997.

LOA, C. C.; LIN, T. L.; WU, C. C.; BRYAN, T.; HOOPER, T.; SCHRADER, D. Specific mucosal IgA immunity in turkey poults infected with turkey coronavirus. Veterinary Immunology and Immunopathology, v. 88, p. 57-64, 2002.

LOZANO, L. F.; HAMMAMI, S.; CASTRO, A. E.; OSBURN, B. Comparision of electron microscopy and polyacrylamide gel electrophoresis in the diagnosis of avian reovirus and rotavirus infections. Avian Diseases, v. 36, p. 183-188, 1992.

MADELEY, C. R.; COSGROVE, B. P. $28 \mathrm{~nm}$ particles in faeces in infantile gastroenteritis. Lancet, v. 2, p. 451-452, 1975.

MCFERRAN, J. B. Adenovirus infections. In: CALNEK, B. W.; BARNES, H. J.; BEARD, C. W.; MCDOUGALD, L. R.; SAIF, Y. F. Diseases of poultry. 10th ed. Ames: lowa state University Press, 1997. p. 607-620.

MCFERRAN, J. B.; ADAIR, B.; CONNOR, T. J. Adenoviral antigens (CELO, QBV, GAL). American Journal of Veterinary Research, v. 36, p. 527-529, 1975.

MCNULTY, M. S. Rotavirus infections. In: CALNEK, B. W.; BARNES, H. J.; BEARD, C. W.; MCDOUGALD, L. R.; SAIF, Y. F. Diseases of poultry. 10th ed. Ames: lowa state University Press, 1997. p. 692-701.

MCNULTY, M. S. Rotavirus infections. In: SAIF, Y. M.; FADLY, A. M.; GLISSON, J. R.; MCDOUGALD, L. R.; NOLAN, L. K.; SWAYNE, D. E. Disease of poultry. 11th ed. Ames: lowa State University Press, 2003. p. 308-320.

MCNULTY, M. S.; ALLAN, G. M.; STUART, J. C. Rotavirus infection in avian species. Veterinary Record, v. 30, p. 319-320, 1978.

MCNULTY, M. S.; ALLAN, G. M.; TODD, D.; MCFERRAN, J. B. Isolation and cell propagation of rotaviruses from turkeys and chickens. Archives of Virology, v. 61, p. 13-21, 1979.

MCNULTY, M. S.; ALLAN, G. M.; TODD, D.; MCFERRAN, J. B.; MCCRACKEN, R. $M$. Isolation from chickens of a rotavirus lacking the rotavirus group antigen. Journal of General Virology, v. 55, p. 405-413, 1981. 
MCNULTY, M. S.; CURRAN, W. L.; MCFERRAN, J. B. Detection of astroviruses in turkey faeces by direct electron microscopy. Veterinary Record, v. 106, p. 561, 1980.

MÉNDEZ, E.; ARIAS, C. F. Astroviruses. In: KNIPE, D. M.; HOWLEY, P. M. Fields virology. 5th ed. Baltimore: Lippincott Willians \& Wilkins, 2007. p. 982-1000.

MEULEMANS, G.; BOSCHMANS, M.; VAN DEN BERG, T. P.; DECAESSTECKER, $M$. Polymerase chain reaction combined with restriction enzyme analysis for detection and differentiation of fowl adenoviruses. Avian Pathology, v. 30, p. 655660, 2001.

MITCHELL, M. A.; MORETÓ, M. Absorptive function of the small intestine: adaptations meeting demand. In: PERRY, G. C. Avian gut function in health and disease. Wallingford: $\mathrm{CABI}$, 2006. p. 43-64.

MONTOGOMERY, R. D.; VILLEGAS, P.; DAWE, D. L.; BROWN, J. Effect of avian reoviruses on lymphoid organ weights and antibody response in chickens. Avian Diseases, v. 29, p. 552-560, 1985.

MORAN JR., E. T. Digestion and absorption of carbohydrates in fowl and events through prenatal development. Journal of Nutrition, v. 115, p. 665-674, 1985.

MUKIIBI-MUKA, G.; JONES, R. C. Local and systemic IgA and IgG responses of chicks to avian reoviruses: effects of age of chick, route of infection and virus strain. Avian Pathology, v. 28, p. 54-60, 1999.

MUNFORD, V. Diversidade sorológica e molecular de rotavirus identificados em humanos em São Paulo, Brasil. 2007. 141f. Tese (Doutorado em Ciências) Instituto de Ciências Biomédicas, Universidade de São Paulo, São Paulo, 2007.

NAGARAJA, K. V.; POMEROY, B. S. Coronaviral Enteritis of Turkeys (Bluecomb Disease). In: CALNEK, B. W.; BARNES, H. J.; BEARD, C. W.; MCDOUGALD, L. R.; SAIF, Y. F. Diseases of poultry. 10th ed. Ames: lowa state University Press, 1997. p. 686-691.

NAQI, S. A.; PANIGRAPHY, B.; HALL, C. F. Bursa of Fabricius, a source of bluecomb infectious agent. Avian Diseases, v. 16, p. 937-939, 1972. 
NICHOLAS, R. A. J.; GODDARD, R. D.; LUFF, P. R. Prevalence of avian nephritis virus in England. Veterinary Record, v. 123, p. 398, 1988.

NURMI, E.; RANTALA, M. New aspects of Salmonella infection in broiler production. Nature, v. 241, p. 210-211, 1973.

OTTO, P.; LIEBLER-TENORIO, E. M.; ELSCHNER, M.; REETZ, J.; LOHREN, U.; DILLER, R. Detection of rotaviruses and intestinal lesions in broiler chicks from flocks with runting and stunting syndrome (RSS). Avian Diseases, v. 50, p. 411-418, 2006.

PANIGRAPHY, B.; NAQI, S. A.; HALL, C. F. Isolation and characterization of viruses associated with transmissible enteritis (bluecomb) of turkeys. Avian Diseases, v. 17, p. 430-438, 1973.

PANTIN-JACKWOOD, M. J.; DAY, J. M.; JACKWOOD, M. W.; SPACKMAN, E. Enteric viruses detected by molecular methods in commercial chicken and turkey flocks in the United States between 2005 and 2006. Avian Diseases, v. 52, p. 235244, 2008.

PANTIN-JACKWOOD, M. J.; SPACKMAN, E.; DAY, M. Pathogenesis of type 2 turkey astroviruses with variant capsid genes in 2-day-old specific pathogen free poults. Avian Pathology, v. 37, p. 193-201, 2008.

PANTIN-JACKWOOD, M. J.; SPACKMAN, E.; DAY, J. M.; RIVES, D. Periodic monitoring of commercial turkeys for enteric viruses indicates continuous presence of astrovirus and rotavirus on the farms. Avian Diseases, v. 51, p. 674-680, 2007.

PATEL, B. L.; DESHMUKH, D. R.; POMEROY, B. S. Fluorescent antibody test for rapid diagnosis of coronaviral enteritis of turkeys (bluecomb). American Journal of Veterinary Research, v. 36, p. 1265-1267, 1975.

PATEL, B. L.; POMEROY, B. S.; GONDER, E.; CRONKITE, C. E. Indirect fluorescent antibody test for the diagnosis of coronaviral enteritis of turkeys (bluecomb). American Journal of Veterinary Research, v. 37, p. 1111-1112, 1976.

PETERSON, E. H.; HYMAS, T. A. Antibiotics in the treatment of an unfamiliar turkey disease. Poultry Science, v. 30, p. 466-468, 1951. 
PHELPS, P. V.; EDENS, F. W.; GILDERSLEEVE, R. P. The post hatch physiology of the turkey poult. III. Yolk depletion and serum metabolites. Comparative

Biochemical Physiology, v. 87, p. 409-415, 1987.

PIERSON, F. W.; FITZGERALD, S. D. Hemorrhagic enteritis and related infections. In: SAIF, Y. M.; FADLY, A. M.; GLISSON, J. R.; MCDOUGALD, L. R.; NOLAN, L. K.; SWAYNE, D. E. Diseases of poultry. 12th ed. Ames: lowa State University Press, 2008. p. 276-286.

PITCOVSKI, J.; MUALEM, M.; REI-KOREN, Z.; KRISPEL, S.; SHMUELI, E.; PERETZ, Y.; GUTTER, B.; GALLILI, G. E.; MICHAEL, A.; GOLDBERG, D. The complete DNA sequence and genome organization of the avian adenovirus, hemorrhagic enteritis virus. Virology, v. 249, p. 307-315, 1998.

POMEROY, B. S.; FENSTERMACHER, R. Hemorrhagic enteritis in turkeys. Poultry Science, v. 16, p. 378-382, 1937.

POMEROY, B. S.; LARSEN, C. T.; DESHMUKL, D. R.; PATEL, B. L. Immunity to transmissible (coronaviral) enteritis of turkeys (bluecomb). American Journal of Veterinary Research, v. 36, p. 553-555, 1975.

POMEROY, B. S.; SIEBURTH, J. M. Bluecomb disease of turkeys. In: ANNUAL MEETING OF THE AMERICAN VETERINARY MEDICAL ASSOCIATION, 90., 1953, Cincinnati. Proceedings... Cincinnati, 1953. p. 321-327.

PORTER, R. E. Bacterial enteritides of poultry. Poultry Science, v. 77, n. 8, p. 11591165, 1998.

QURESHI, M. A.; YU, M.; SAIF, Y. M. A novel "small round virus" inducing poult enteritis and mortality syndrome and associated immune alterations. Avian

Diseases, v. 44, p. 275-283, 2000.

RAMIG, R. F.; CIARLET, M.; MERTENS, P. P. C.; DERMODY, T. S. Rotavirus. In: FAUQUET, C. M.; MAYO, M. A.; MANILOFF, J.; DESSELBERGER, U.; BALL, L. A. Virus taxonomy: eighth report of the international comittee on the taxonomy of viruses. San Diego: Elsevier Academic Press, 2005. p. 493-496.

RELATÓRIO ANUAL DA UNIÃO BRASILEIRA DE AVICULTURA, 2009. Disponível em: <http://www.abef.org.br>. Acesso em: 12 Jan. 2011. 
REYNOLDS, D. L. Multicausal enteric diseases. In: SAIF, Y. M.; FADLY, A. M.; GLISSON, J. R.; MCDOUGALD, L. R.; NOLAN, L. K.; SWAYNE, D. E. Disease of poultry. 11th ed. Ames: lowa State University Press, 2003. p. 1169-1171.

REYNOLDS, D. L.; SAIF, Y. M. Astrovirus: a cause of an enteric disease in turkey poults. Avian Diseases, v. 30, p. 728-735, 1986.

REYNOLDS, D. L.; SAIF, Y. M.; THEIL, K. W. A survey of enteric viruses of turkey poults. Avian Diseases, v. 31, p. 89-98, 1987 a.

REYNOLDS, D. L.; SAIF, Y. M.; THEIL, K. W. Enteric viral infections of turkey poults: incidence of infection. Avian Diseases, v. 31, p. 272-276, 1987b.

REYNOLDS D. L.; SCHULTZ-CHERRY S. L. Astrovirus infections. SAIF, Y. M.; FADLY, A. M.; GLISSON, J. R.; MCDOUGALD, L. R.; NOLAN, L. K.; SWAYNE, D. E. Disease of poultry. 11th ed. Ames: lowa State University Press, 2003. p. 320-326

RITCHIE, A. E.; DESHMUKH, D. R.; LARSEN, C. T.; POMEROY B. S. Electron microscopy of coronavirus-like particles characteristic of turkey bluecomb disease. Avian Diseases, v. 17, p. 546-558, 1973.

ROSENBERGER, J. K.; FRIES, P. A.; CLOUD, S. S.; WILSON, R. A. In vitro and in vivo characterization of Escherichia coli. II. Factors associated with pathogenicity. Avian Diseases, v. 29, p. 1094-1107, 1986.

ROSENBERGER, J. K.; OLSON, N. O. Viral Arthritis. In: CALNEK, B. W.; BARNES, H. J.; BEARD, C. W.; MCDOUGALD, L. R.; SAIF, Y. F. Diseases of poultry. 10th ed. Ames: lowa state University Press, 1997. p. 711-719.

RUFF, M. D.; ROSENBERGER, J. K. Concurrent infections with reoviruses and coccidian in broilers. Avian Diseases, v. 29, p. 465-478, 1985.

SAHU, S. P.; OLSON, N. O. Comparison of the characteristics of avian reoviruses isolated from the digestive and respiratory tracts, with viruses isolated from the synovia. American Journal of Veterinary Research, v. 36, p. 847-850, 1975.

SAIF, Y. M. Viral Enteric Infections. In: SAIF, Y. M.; FADLY, A. M.; GLISSON, J. R.; MCDOUGALD, L. R.; NOLAN, L. K.; SWAYNE, D. E. Diseases of poultry. 12th ed. Ames: lowa State University Press, 2008. p. 329-330. 
SAIF, Y. M.; SAIF, L. J.; HOFACRE, C. L.; HAYHOW, C.; SWAYNE, D. E.; DEARTH, R. N. A small round virus associated with enteritis in turkey poults. Avian Diseases, v. 34, p. 762-764, 1990.

SAIF, L. J.; SAIF, Y. M.; THEIL, K. W. Enteric viruses in diarrheic turkey poults. Avian Diseases, v. 29, p. 798-811, 1985.

SCHNITZER, T. J. Protein coding assignment of the $\mathrm{S}$ genes of the avian reovirus S1133. Virology, v. 141, p. 167-170, 1985.

SCOTT, M.; MCFERRAN, J. B. Isolation of adenoviruses from turkeys. Avian Diseases, v. 16, p. 413-420, 1972.

SELLERS, H. S.; KOCI, M. D.; LINNEMANN, E.; KELLEY, L. A.; SCHULTZCHERRY, S. Development of a multiplex reverse transcription-polymerase chain reaction diagnostic test specific for turkey astrovirus and coronavirus. Avian Diseases, v. 48, p. 531-539, 2004.

SHARMA, J. M. Response of specific-pathogen-free turkeys to vaccines derived from marble spleen disease virus and hemorrhagic enteritis virus. Avian Diseases, v. 38, p. 523-530, 1994.

SHARMA, R.; FERNANDEZ, F.; HILTON, M.; SCHUMACHER, U. The influence of diet on the mucin carbohydrates in the chick intestinal tract. Cellular and Molecular Life Sciences, v. 53, p. 935-942, 1997.

SHATKLIN, A. J.; SIPE, J. D.; LOH, P. Separation of ten reovirus genome segments by polyacrylamide gel electrophoresis. Journal of Virology, v. 2, n. 10, p. 986-991, 1968.

SHIVAPRASAD, H. L.; WOOLCOCK, P. R.; MCFARLAND, M. D. Group I avian adenovirus and avian adeno-associated virus in turkey poults with inclusion body hepatitis. Avian Pathology, v. 30, p. 661-666, 2001.

SIEBURTH, J. MCN.; JOHNSON, E. P. Transmissible enteritis of turkeys (bluecomb disease) 1. Preliminary studies. Poultry Science, v. 36, p. 256-261, 1957.

SIEBURTH, J. MCN.; POMEROY M. S. Bluecomb disease in turkeys III. Preliminary studies on etiology. In: ANNUAL MEETING OF THE AMERICAN 
VETERINARY MEDICAL ASSOCIATION, 92., 1955, Cincinatti. Proceedings... Cincinnati, 1955. p. 301-306.

SILIM, A.; THORSEN, J. Hemorrhagic enteritis: virus distribution and sequential development of antibody in turkeys. Avian Diseases, v. 25, p. 444-453, 1981.

SILVA, S. E. L.; BONETTI, A. M.; PETROCELLI, A. T. M.; FERRARI, H. F.; LUVIZOTTO, M. C. R.; CARDOSO, T. C. Detection of turkey astrovirus in young poults affected with poult enteritis complex in Brazil. The Journal of Veterinary Medical Science, v. 70, n. 6, p. 629-631, 2008.

SILVA, S. E. L.; BONETTI, A. M.; PETROCELLI, A. T. M.; FERRARI, H. F.; LUVIZOTTO, M. C. R.; CARDOSO, T. C. Epidemiological aspects of astrovirus and coronavirus in poults in the south eastern region of Brazil. Brazilian Journal of Microbiology, v. 40, p. 248-253, 2009.

SIMMONS, D. G.; MILLER, S. E.; GRAY, J. G.; BLALOCK, H. G.; COLWELL, W. M. Isolation and identification of a turkey respiratory adenovirus. Avian Diseases, v. 20, p. 65-74, 1976.

SMIRNOV, A.; PEREZ, R.; AMIT-ROMACH, E.; SKLAN, D.; UNI, Z. Mucin dynamics and microbial populations in chicken small intestine are changed by dietary probiotic and antibiotic growth promoter supplementation. Journal of Nutrition, v. 135, p. 187-192, 2005.

SMIRNOV, A.; SKLAN, D.; UNI, Z. Mucin dynamics in the chick small intestine are altered by starvation. Journal of Nutrition, v. 134, p. 736-742, p. 2004.

SPAAN, W. J. M.; BRIAN, D.; CAVANAGH, D.; DE GROOT, R. J.; ENJUANES, L.; GORBALENYA, A. E.; HOLMES, K. V.; MASTERS, P.; ROTTIER, P.; TAGUCHI, F.; TALBOT, P. Coronaviridae. In: FAUQUET; C. M.; MAYO, M. A.; MANILOFF, J.; DESSELBERGER, U.; BALL, L. A. Virus taxonomy: eighth report of the international comittee on the taxonomy of viruses. San Diego: Elsevier Academic Press, 2005. p. 956-973.

SPACKMAN, E.; KAPCZYNSKI, D.; SELLERS, H. Multiplex real-time reverse transcription-polymerase chain reaction for the detection of three viruses associated with poult enteritis complex: turkey astrovirus, turkey coronavirus, and turkey reovirus. Avian Diseases, v. 49, p. 86-91, 2005. 
SURESH, M.; SHARMA, J. M. Pathogenesis of type II avian adenovirus infection in turkeys: In vivo immune cell tropism and tissue distribution of the virus. Journal of Virology, v. 70, p. 30-36, 1996.

SUTJIPTO, S.; MILLER, S. E.; SIMMONS, D. G.; DILLMAN, R. C. Physicochemical Characterization and pathogenicity studies of two turkey adenovirus isolants. Avian Diseases, v. 21, p. 549-556, 1977.

TAMEHIRO, C. Y.; ALFIERI, A. F.; ALFIERI, A. A. Infecções entéricas de origem viral. In: REVOLLEDO, L.; FERREIRA, A. J. P. Patologia aviária. Barueri: Manole, 2009. p. 245-257.

TANG, Y.; MURGIA, A. M.; SAIF, Y. M. Molecular characterization of the capsid gene of two serotypes of turkey astroviruses. Avian Diseases, v. 49, p. 514-519, 2005.

TEIXEIRA, M. C. B.; LUVIZOTTO, M. C. R.; FERRARI, H. F.; MENDES, A. R.; SILVA, S. E. L.; CARDOSO, T. C. Detection of turkey coronavirus in commercial turkey poults in Brazil. Avian Pathology, v. 36, p. 29-33, 2007.

THE UNIVERSAL VIRUS DATABASE OF THE INTERNATIONAL COMMITTEE ON TAXONOMY OF VIRUSES. Version 3, 2004. Disponível em: <http://www.ictvdb.org/>. Acesso em: 06 Jan. 2011.

THOUVENELLE, M. L.; HAYNES, J. S.; REYNOLDS, D. L. Astrovirus infection in hatchling turkeys: histologic, morphometric, and ultrastructural findings. Avian Diseases, v. 39; p. 328-336, 1995.

THOUVENELLE, M. L.; HAYNES, J. S.; SELL, J. L.; REYNOLDS, D. L. Astrovirus infection in hatchling turkeys: alterations in intestinal maltase activity. Avian Diseases, v. 39, p. 343-348, 1995.

TODD, D.; MCNULTY, M. S. Electrophoretic variation of avian rotavirus RNA in polyacrylamide gels. Avian Pathology, v. 15, p. 149-159, 1986.

TOLIN, S. A.; DOMERMUTH, C. H. Enteritis of turkeys: electron microscopy of the causal virus. Avian Diseases, v. 19, p. 118-125, 1975.

TRAMPEL, D. W.; KINDEN, D. A.; SOLORZANO, R. F.; STOGSDILL, P. L. Parvovirus-like enteropathy in Missouri turkeys. Avian Diseases, v. 27, p. 49-54, 1983. 
TRUSCOTT, R. B. Transmissible enteritis of turkeys: disease reproduction. Avian Diseases, v. 12, p. 239-245, 1968.

TUMLIN, J. T.; POMEROY, B. S. Bluecomb disease of turkeys. V. Preliminary studies on parenteral immunity and serum neutralization. American Journal of Veterinary Research, v. 19, p. 725-728, 1958.

UILIANA, G.; VILLAREAL, L. Y. B.; VALENZUELA, C.; BRANDÃO, P. E.; JEREZ, J. A.; FERREIRA, A. J. P. Detecção e isolamento de rotavirus aviário em células MA104 de aves com e sem diarreia. Conferência Apinco de Ciência e Tecnologia Avícolas, São Paulo, p. 216, 2006. Suplemento 8.

UNI, Z. Early development of small intestinal function. In: PERRY, G. C. Avian gut function in health and disease. Wallingford: CABI, 2006. p. 29-42.

UNI, Z.; NOY, Y.; SKLAN, D. Posthatch changes in morphology and function of the small intestines in heavy-and light -strain chicks. Poultry Science, v. 74, p. 1622 1629, 1995.

UNI, Z.; NOY, Y.; SKLAN, D. Posthatch development of small intestinal function in the poult. Poultry Science, v. 78, p. 215-222, 1999.

UNI, Z.; PLATIN, R.; SKLAN, D. Cell proliferation in chicken intestinal epithelium occurs both in the crypt and along the villus. Journal of Comparative Physiology (B), v. 168, p. 241-247, 1998.

UNI, Z.; SMIRNOV, A.; SKLAN, D. Pre-and posthatch development of goblets cells in the broiuler small intestine: effect of delayed access to feed. Poultry Science, v. 82, p. 320-327, 2003.

UNITED STATES DEPARTAMENT OF AGRICULTURE. 2010. Disponível em: $<$ http://www.fas.usda.gov/dlp/circular/2010/livestock_poultryfull101510.pdf>. Acesso em: 12 Jan. 2011.

VAN DEN HURK, J. V. Efficacy of avirulent hemorrhagic enteritis virus propagated in turkey leukocyte cultures for vaccination against hemorrhagic enteritis in turkeys.

Avian Diseases, v. 34, p. 26-35, 1990. 
VERVELDE, L.; JEURISSEN, S. H. Postnatal development of intra-epithelial leukocytes in the chicken digestive tract: phenotypical characterization in situ. Cell and Tissue Research, v. 274, p. 295-301, 1993.

VILLARREAL, L. Y. B.; ASSAYAG, M. S.; BRANDÃO, P. E.; CHACÓN, J. L. V.; BUNGER, A. N. D.; ASTOLFI-FERREIRA, C. S.; GOMES, C. R.; JONES, R. C.; FERREIRA, A. J. P. Identification of turkey astrovirus and turkeys coronavirus in an outbreak of poult enteritis and mortality syndrome. Brazilian Journal of Poultry Science, v. 8, n. 2, p. 131-135, 2006.

WANI, S. A.; BHAT, M. A.; ISHAQ, S. M.; ASHRAFI, M. A.; BUCHH, A. S.; HAQ, M. Detection of a mammalian-like group $A$ rotavirus in diarrhoeic chicken. Veterinary Microbiology, v. 94, p. 13-18, 2003.

WIGAND, R.; BARTHA, R. S.; CREIZIN, R. S.; ESCHE, H.; GINSBERG, H. S.; GREEN, M.; HIERHOLZER, J. C.; KALTER, S. S.; MCFERRAN, J. B.; PETTERSSON, U.; RUSSELL, W. C.; WADELL, G. Adenoviridae: Second Report. Intervirology, v. 18, p. 169-176, 1982.

WOOD, G. W.; NICHOLAS, R. A. J.; HEBERT, C. N.; THORNTON, D. H. Serological comparisons of avian reoviruses. Journal of Comparative Pathology, v. 90, p. 2938, 1980.

WOOLCOCK, P. R.; SHIVAPRASAD, H. L. Electron microscopic identification of viruses associated with poult enteritis in turkeys grown in California 1993-2003.

Avian Diseases, v. 52, p. 209-213, 2008.

WOOLEY, R. E.; GRATZEK, J. B. Certain characteristics of viruses isolated from turkeys with Bluecomb. American Journal of Veterinary Research, v. 30, p. 10271033, 1969.

XIE, Z.; FADL, A. A.; GIRSHICK, T.; KHAN, M. I. Detection of avian adenoviruses. Avian Diseases, v. 43, p. 98-105, 1999.

YAMAUCHI, K.; KAMISOYAMA, H.; ISSHIKI, Y. Effects of fastng and re-feeding on structures of the intestinal villi and epithelial cells in White Leghorn hens. British Poultry Science, v. 37, p. 909-921, 1996.

YASON, C. V.; SCHAT, K. A. Pathogenesis of rotavirus infection in turkey poults. Avian Pathology, v. 15, p. 421-435, 1986. 
YASON, C. V.; SUMMERS, B. A.; SCHAT, K. A. Pathogenesis of rotavirus infection in various age groups of chickens and turkeys: pathology. American Journal of Veterinary Research, v. 48, p. 927-938, 1987.

YU, M.; ISMAIL, M. M.; QURESHI, M. A.; DEARTH, R. N.; BARNES, H. J.; SAIF, Y. $M$. Viral agents associated with poult enteritis and mortality syndrome : the role of a small round virus and a turkey coronavirus. Avian Diseases, v. 44, p. 297-304, 2000. 


\section{APÊNDICE A}

Preparação da Solução Salina Fostatada (PBS)

\begin{tabular}{|l|c|}
\hline \multicolumn{1}{|c|}{ Reagentes } & Quantidades \\
\hline Fosfato bipotássico $\left(\mathrm{K}_{2} \mathrm{HPO}_{4}\right)$ & $0,165 \mathrm{~g}$ \\
\hline Dihidrogenofosfato de monopotássio $\left(\mathrm{KH}_{2} \mathrm{PO}_{4}\right)$ & $0,8445 \mathrm{~g}$ \\
\hline Cloreto de sódio & $8,7664 \mathrm{~g}$ \\
\hline Água ultra-pura & $1000 \mathrm{~mL}$ \\
\hline
\end{tabular}

Homogeneizar todos os reagente até que os sais estejam completamente dissolvidos. Armazenar a $25^{\circ} \mathrm{C}$.

Preparação do Tampão Tris HCl - EDTA pH 8,0 (TE)

\begin{tabular}{|l|l|}
\hline \multicolumn{1}{|c|}{ Reagentes } & \multicolumn{1}{c|}{ Quantidades } \\
\hline EDTA 0,5 M & $0,4 \mathrm{~mL}$ \\
\hline Tris HCl 1 M & $2 \mathrm{~mL}$ \\
\hline Água ultra pura & $197,6 \mathrm{~mL}$ \\
\hline
\end{tabular}

Homogeneizar todos os reagentes e armazenar a solução sob refrigeração a 8ํㅡ. 


\section{APÊNDICE B}

Dados constantes nas fichas clínicas e resultados obtidos na detecção viral por RT-PCR.

\begin{tabular}{|c|c|c|c|c|c|c|c|c|c|c|c|c|}
\hline Amostra & Idade & Localidade & $\begin{array}{l}\text { Data da } \\
\text { coleta }\end{array}$ & Sinais clínicos & TAV & HEV & $\begin{array}{c}\text { TAstV } \\
-1\end{array}$ & $\begin{array}{c}\text { TAstV } \\
-2\end{array}$ & ANV & TCoV & Reovirus & Rotavirus \\
\hline $\begin{array}{c}\text { P1 } \\
\text { 252-04 } \\
\text { Fêmeas }\end{array}$ & 14 dias & Uberlândia-MG & $27 / 01 / 2004$ & $\begin{array}{c}\text { Diarreia, sem } \\
\text { resposta à } \\
\text { medicação com } \\
\text { antibióticos, } \\
\text { mortalidade (5\%) } \\
\text { e enterite } \\
\text { severa. Sinais } \\
\text { clínicos ao redor } \\
\text { do } 7^{\circ} \text { dia de vida. }\end{array}$ & - & - & - & + & - & - & - & - \\
\hline $\begin{array}{c}\text { P1 } \\
30217 / 03 \\
\text { Fêmeas }\end{array}$ & 14 dias & Uberlândia-MG & $27 / 01 / 2004$ & $\begin{array}{l}\text { Diarreia, sem } \\
\text { resposta à } \\
\text { medicação com } \\
\text { antibióticos, } \\
\text { mortalidade (5\%) } \\
\text { e enterite } \\
\text { severa. Sinais } \\
\text { clínicos ao redor } \\
\text { do } 7^{\circ} \text { dia de vida. }\end{array}$ & - & - & - & - & - & - & - & + \\
\hline $\begin{array}{c}\mathrm{P1} \\
\text { 30150/03 } \\
\text { Am.1 }\end{array}$ & 19 dias & Sem informação & $27 / 01 / 2004$ & $\begin{array}{c}\text { Diarreia, sem } \\
\text { resposta à } \\
\text { medicação com } \\
\text { antibióticos, } \\
\text { mortalidade (5\%) } \\
\text { e enterite } \\
\text { severa. Sinais } \\
\text { clínicos ao redor } \\
\text { do } 7^{00} \text { dia de vida. }\end{array}$ & - & - & + & - & - & - & - & - \\
\hline
\end{tabular}


(Continuação)

\begin{tabular}{|c|c|c|c|c|c|c|c|c|c|c|c|c|}
\hline Amostra & Idade & Localidade & $\begin{array}{c}\text { Data da } \\
\text { coleta }\end{array}$ & Sinais clínicos & TAV & HEV & $\begin{array}{c}\text { TAstV } \\
-1 \\
\end{array}$ & $\begin{array}{c}\text { TAstV } \\
-2 \\
\end{array}$ & ANV & TCoV & Reovirus & Rotavirus \\
\hline $\begin{array}{c}\text { P1 } \\
\text { 30150/03 } \\
\text { Am.2 } \\
\text { Fêmeas }\end{array}$ & 19 dias & Uberlândia-MG & 27/01/2004 & $\begin{array}{l}\text { Diarreia, sem } \\
\text { resposta à } \\
\text { medicação com } \\
\text { antibióticos, } \\
\text { mortalidade (5\%) } \\
\text { e enterite } \\
\text { severa. Sinais } \\
\text { clínicos ao redor } \\
\text { do } 7^{\circ} \text { dia de vida. }\end{array}$ & - & - & + & + & - & + & - & + \\
\hline $\begin{array}{c}\text { P2 } \\
173 A\end{array}$ & 7 semanas & Chapecó-SC & 02/02/2004 & $\begin{array}{c}\text { Diarreia, perda } \\
\text { de peso, penas } \\
\text { eriçadas, } \\
\text { prostração, } \\
\text { inflamação de } \\
\text { seringe e olhos, } \\
\text { asas caídas } \\
\text { (aves refugos) }\end{array}$ & + & - & + & + & + & + & - & + \\
\hline $\begin{array}{c}\text { P2 } \\
173 B\end{array}$ & 6 semanas & Chapecó-SC & 02/02/2004 & $\begin{array}{l}\text { Diarreia, perda } \\
\text { de peso, penas } \\
\text { eriçadas, } \\
\text { prostração, } \\
\text { inflamação de } \\
\text { seringe e olhos, } \\
\text { asas caídas } \\
\text { (aves refugos) }\end{array}$ & - & - & + & + & - & + & - & + \\
\hline $\begin{array}{c}\mathrm{P} 2 \\
174\end{array}$ & 7 semanas & Chapecó-SC & 03/02/2004 & $\begin{array}{c}\text { Diarreia, } \\
\text { prostração, } \\
\text { penas eriçadas, } \\
\text { cabeça inchada, } \\
\text { agitacao, } \\
\text { candidiase, TGI } \\
\text { com conteúdo } \\
\text { liq. e gás }\end{array}$ & - & - & + & + & - & + & - & - \\
\hline
\end{tabular}




\begin{tabular}{|c|c|c|c|c|c|c|c|c|c|c|c|c|}
\hline & & & & & & & & & & & & Continuação) \\
\hline Amostra & Idade & Localidade & $\begin{array}{c}\text { Data da } \\
\text { coleta }\end{array}$ & Sinais clínicos & TAV & HEV & $\begin{array}{c}\text { TAstV } \\
-1 \\
\end{array}$ & $\begin{array}{c}\text { TAstV } \\
-2 \\
\end{array}$ & ANV & TCoV & Reovirus & Rotavirus \\
\hline $\begin{array}{c}\text { P2 } \\
175\end{array}$ & 51 dias & Chapecó-SC & 03/02/2004 & Diarreia, enterite & - & - & + & + & - & - & - & + \\
\hline $\begin{array}{c}\text { P3 } \\
\text { NP06 } \\
\text { 10/03 } \\
\text { Amostra } \\
\text { A }\end{array}$ & 19 dias & Guatambú-SC & 04/05/2004 & $\begin{array}{c}\text { Apatia, } \\
\text { diminuição do } \\
\text { consumo de } \\
\text { ração, aves } \\
\text { encorujadas, } \\
\text { buscam fonte de } \\
\text { calor, diarreia } \\
\text { aquosa. }\end{array}$ & - & - & + & + & + & + & - & + \\
\hline $\begin{array}{c}\text { P4 } \\
\text { lote12/04 } \\
\text { Am.B }\end{array}$ & 10 dias & Guatambú-SC & $04 / 05 / 2004$ & $\begin{array}{c}\text { Prostração, } \\
\text { anorexia, } \\
\text { agitação, fezes } \\
\text { com grumos e } \\
\text { presença de } \\
\text { muco } \\
\end{array}$ & - & - & + & + & - & + & - & + \\
\hline $\begin{array}{c}\text { P6 } \\
\text { lote12/04 } \\
\text { Am.D }\end{array}$ & 19 dias & Guatambú-SC & $11 / 05 / 2004$ & $\begin{array}{l}\text { Comportamento } \\
\text { alterado, frio, } \\
\text { baixo consumo } \\
\text { de ração, } \\
\text { prostração, } \\
\text { refugagem, } \\
\text { diarreia aquosa. }\end{array}$ & - & - & - & + & - & + & - & - \\
\hline $\begin{array}{c}\text { P7 } \\
04 / 04 \\
\text { Am.2 }\end{array}$ & $\begin{array}{c}13 \\
\text { semanas }\end{array}$ & Guatambú-SC & $24 / 05 / 2004$ & $\begin{array}{c}\text { Enterite } \\
\text { inespecífica há } \\
19 \text { dias, } \\
\text { refugagem, } \\
\text { candidíase após } \\
\text { redução da } \\
\text { mortalidade, } \\
\text { reações } \\
\text { respiratórias e } \\
\text { aerossaculite. }\end{array}$ & - & - & + & - & + & + & - & - \\
\hline
\end{tabular}




\begin{tabular}{|c|c|c|c|c|c|c|c|c|c|c|c|c|}
\hline & & & & & & & & & & & & Continuação) \\
\hline Amostra & Idade & Localidade & $\begin{array}{c}\text { Data da } \\
\text { coleta }\end{array}$ & Sinais clínicos & TAV & HEV & $\begin{array}{c}\text { TAstV } \\
-1\end{array}$ & $\begin{array}{c}\text { TAstV } \\
-2\end{array}$ & ANV & TCoV & Reovirus & Rotavirus \\
\hline $\begin{array}{c}\text { P8 } \\
\text { lote03/04 } \\
\text { amostra1 }\end{array}$ & $\begin{array}{c}13 \\
\text { semanas }\end{array}$ & Guatambú-SC & $24 / 05 / 2004$ & $\begin{array}{c}\text { Enterite } \\
\text { inespecífica há } \\
19 \text { dias, } \\
\text { refugagem, } \\
\text { candidíase após } \\
\text { redução da } \\
\text { mortalidade, } \\
\text { reações } \\
\text { respiratórias e } \\
\text { aerossaculite. }\end{array}$ & + & - & + & - & + & + & - & - \\
\hline $\begin{array}{c}\mathrm{P9} \\
16 \mathrm{P} \\
\text { (fêmeas) }\end{array}$ & 7 semanas & Guatambú-SC & 07/07/2004 & Monitoria & - & - & + & - & - & - & - & - \\
\hline $\begin{array}{c}\text { P9 } \\
16 \mathrm{P} \\
\text { (machos) } \\
\end{array}$ & 7 semanas & Guatambú-SC & 07/07/2004 & Monitoria & - & - & + & - & - & - & - & + \\
\hline $\begin{array}{c}\mathrm{P} 10 \\
17 \mathrm{P} \\
\text { (machos) }\end{array}$ & 8 semanas & Guatambú-SC & $16 / 07 / 2004$ & $\begin{array}{l}\text { Diarreia, } \\
\text { prostração, } \\
\text { diminuição } \\
\text { consumo de } \\
\text { ração } \\
\end{array}$ & - & - & - & + & - & - & - & - \\
\hline $\begin{array}{c}\text { P10 } \\
17 P \\
\text { (fêmeas) }\end{array}$ & 8 semanas & Guatambú-SC & $16 / 07 / 2004$ & $\begin{array}{c}\text { Diarreia, } \\
\text { prostração, } \\
\text { diminuição } \\
\text { consumo de } \\
\text { ração }\end{array}$ & - & - & - & + & - & + & - & + \\
\hline $\begin{array}{c}P 11 \\
(24) \\
0196834\end{array}$ & 80 dias & Uberlândia-MG & $11 / 06 / 2005$ & $\begin{array}{c}\text { Diarreia, } \\
\text { prostração, } \\
\text { fraqueza e } \\
\text { manqueira, } \\
\text { enterite, fígado } \\
\text { esverdeado e } \\
\text { artrite }\end{array}$ & - & - & + & + & + & - & - & - \\
\hline
\end{tabular}




\begin{tabular}{|c|c|c|c|c|c|c|c|c|c|c|c|c|}
\hline & & & & & & & & & & & & Continuação \\
\hline Amostra & Idade & Localidade & $\begin{array}{c}\text { Data da } \\
\text { coleta }\end{array}$ & Sinais clínicos & TAV & HEV & $\begin{array}{c}\text { TAstV } \\
-1 \\
\end{array}$ & $\begin{array}{c}\text { TAstV } \\
-2\end{array}$ & ANV & TCoV & Reovirus & Rotavirus \\
\hline $\begin{array}{c}P 11 \\
(23) \\
0195417\end{array}$ & 100 dias & Uberlândia-MG & $11 / 06 / 2005$ & $\begin{array}{c}\text { Diarreia intensa } \\
\text { c/ coloração } \\
\text { caramelada, } \\
\text { figado e ceco } \\
\text { aumentados }\end{array}$ & - & - & - & + & - & + & + & + \\
\hline $\begin{array}{c}P 11 \\
(22) \\
0195416\end{array}$ & 104 dias & Uberlândia-MG & $11 / 06 / 2005$ & $\begin{array}{l}\text { Baixo ganho de } \\
\text { peso, apatia, } \\
\text { diarreia, figado } \\
\text { aumentado e } \\
\text { mucosa } \\
\text { intestinal } \\
\text { edemaciada }\end{array}$ & - & - & + & + & + & + & - & - \\
\hline 97D M14 & 4 semanas & Guatambú-SC & $27 / 06 / 2006$ & $\begin{array}{c}\text { Apatia, agitação, } \\
\text { diarreia, } \\
\text { aumento de } \\
\text { mortalidade }\end{array}$ & - & - & + & - & - & + & - & + \\
\hline $\begin{array}{c}\text { 97D } \\
14 / 06\end{array}$ & 4 semanas & Guatambú-SC & 27/06/2006 & $\begin{array}{c}\text { Apatia, agitação, } \\
\text { diarreia, } \\
\text { aumento de } \\
\text { mortalidade }\end{array}$ & - & - & + & + & - & + & - & + \\
\hline $239-1$ & 28 dias & Guatambú-SC & $15 / 06 / 2007$ & $\begin{array}{c}\text { Diarreia, } \\
\text { refugagem, } \\
\text { desidratação, } \\
\text { mortalidade e } \\
\text { fezes aquosas e } \\
\text { sanguinolentas }\end{array}$ & - & - & + & + & - & + & - & + \\
\hline $239-2$ & 18 dias & Guatambú-SC & $15 / 06 / 2007$ & $\begin{array}{c}\text { Diarreia, } \\
\text { refugagem, } \\
\text { baixo consumo } \\
\text { de ração, aves } \\
\text { "encorujadas" e } \\
\text { fezes aquosas e } \\
\text { sanguinolentas }\end{array}$ & - & - & + & - & - & + & - & + \\
\hline
\end{tabular}




\begin{tabular}{|c|c|c|c|c|c|c|c|c|c|c|c|c|}
\hline & & & & & & & & & & & & Continuação \\
\hline Amostra & Idade & Localidade & $\begin{array}{c}\text { Data da } \\
\text { coleta }\end{array}$ & Sinais clínicos & TAV & HEV & $\begin{array}{c}\text { TAstV } \\
-1\end{array}$ & $\begin{array}{c}\text { TAstV } \\
-2\end{array}$ & ANV & TCoV & Reovirus & Rotavirus \\
\hline $239-3$ & 33 dias & Guatambú-SC & $15 / 06 / 2007$ & $\begin{array}{c}\text { Diarreia, } \\
\text { refugagem, } \\
\text { baixo consumo } \\
\text { de ração, aves } \\
\text { "encorujadas" e } \\
\text { fezes aquosas e } \\
\text { sanguinolentas }\end{array}$ & - & - & + & + & + & + & - & + \\
\hline $239-4$ & 26 dias & Guatambú-SC & $15 / 06 / 2007$ & $\begin{array}{c}\text { Diarreia, } \\
\text { refugagem, } \\
\text { baixo consumo } \\
\text { de ração, aves } \\
\text { "encorujadas" e } \\
\text { fezes aquosas e } \\
\text { sanguinolentas }\end{array}$ & - & - & + & - & - & + & - & + \\
\hline $264-1$ & 8 semanas & Guatambú-SC & 05/12/2007 & $\begin{array}{c}\text { Prostração, } \\
\text { queda no } \\
\text { consumo de } \\
\text { água e ração, } \\
\text { diarreia, } \\
\text { claudicação e } \\
\text { fezes } \\
\text { sanguinolentas }\end{array}$ & + & - & + & + & + & + & - & + \\
\hline $264-2$ & 8 semanas & Guatambú-SC & 05/12/2007 & $\begin{array}{c}\text { Prostração, } \\
\text { queda no } \\
\text { consumo de } \\
\text { água e ração, } \\
\text { diarreia, e fezes } \\
\text { sanguinolentas }\end{array}$ & + & - & - & - & + & + & - & + \\
\hline $267-1$ & $\begin{array}{c}6 \text { e } 7 \\
\text { semanas }\end{array}$ & Guatambú-SC & 20/12/2007 & $\begin{array}{l}\text { Diminuição do } \\
\text { consumo de } \\
\text { ração, diarreia, } \\
\text { agitação, fezes } \\
\text { aquosas }\end{array}$ & - & - & + & - & + & + & - & + \\
\hline
\end{tabular}




\begin{tabular}{|c|c|c|c|c|c|c|c|c|c|c|c|c|}
\hline & & & & & & & & & & & & Continuação) \\
\hline Amostra & Idade & Localidade & $\begin{array}{c}\text { Data da } \\
\text { coleta }\end{array}$ & Sinais clínicos & TAV & HEV & $\begin{array}{c}\text { TAstV } \\
-1\end{array}$ & $\begin{array}{c}\text { TAstV } \\
-2\end{array}$ & ANV & TCoV & Reovirus & Rotavirus \\
\hline $267-2$ & $\begin{array}{c}6 \text { e } 7 \\
\text { semanas }\end{array}$ & Sem informação & $20 / 12 / 2007$ & Sem informação & - & - & + & - & + & + & - & + \\
\hline $267-3$ & $\begin{array}{c}12 \\
\text { semanas }\end{array}$ & Sem informação & $20 / 12 / 2007$ & Sem informação & - & - & + & - & + & - & - & + \\
\hline $267-4$ & $\begin{array}{c}12 \\
\text { semanas }\end{array}$ & Guatambú-SC & 20/12/2007 & $\begin{array}{l}\text { Diminuição do } \\
\text { consumo de } \\
\text { ração, diarreia e } \\
\text { fezes aquosas }\end{array}$ & - & - & + & + & + & + & - & - \\
\hline $267-5$ & $\begin{array}{c}12 \\
\text { semanas }\end{array}$ & Guatambú-SC & 20/12/2007 & & - & - & + & - & + & + & - & + \\
\hline $269-1$ & 44 dias & Chapecó-SC & $13 / 01 / 2008$ & $\begin{array}{c}\text { Cama } \\
\text { emplastada e } \\
\text { diarreia }\end{array}$ & - & - & + & - & + & + & - & + \\
\hline $269-2$ & 59 dias & Chapecó-SC & $13 / 01 / 2008$ & $\begin{array}{c}\text { Cama } \\
\text { emplastada e } \\
\text { diarreia }\end{array}$ & - & - & - & + & - & + & - & - \\
\hline $269-3$ & 14 dias & Chapecó-SC & $13 / 01 / 2008$ & $\begin{array}{c}\text { Diarreia, } \\
\text { refugagem, } \\
\text { baixo consumo } \\
\text { de ração e aves } \\
\text { "encorujadas" }\end{array}$ & - & - & + & - & + & + & + & + \\
\hline $269-4$ & 21 dias & Chapecó-SC & $13 / 01 / 2008$ & $\begin{array}{l}\text { Diminuição do } \\
\text { consumo de } \\
\text { ração, diarreia, } \\
\text { fezes } \\
\text { sanguinolentas e } \\
\text { aquosas e muita } \\
\text { agitação. }\end{array}$ & - & - & + & + & + & + & + & - \\
\hline $273-1$ & 119 dias & Chapecó-SC & 29/02/2008 & $\begin{array}{l}\text { Aves prostradas } \\
\text { com diarreia } \\
\text { fétida }\end{array}$ & - & - & + & - & - & + & - & - \\
\hline
\end{tabular}




\begin{tabular}{|c|c|c|c|c|c|c|c|c|c|c|c|c|}
\hline Amostra & Idade & Localidade & $\begin{array}{c}\text { Data da } \\
\text { coleta }\end{array}$ & Sinais clínicos & TAV & HEV & $\begin{array}{c}\text { TAstV } \\
-1\end{array}$ & $\begin{array}{c}\text { TAstV } \\
-2\end{array}$ & ANV & TCoV & Reovirus & Rotavirus \\
\hline $273-2$ & 45 dias & Chapecó-SC & 29/02/2008 & $\begin{array}{l}\text { Aves prostradas, } \\
\text { diminuição do } \\
\text { consumo de } \\
\text { ração, fezes } \\
\text { aquosas }\end{array}$ & - & - & - & - & - & + & - & - \\
\hline $273-3$ & 26 dias & Guatambú-SC & 29/02/2008 & $\begin{array}{c}\text { Aves } \\
\text { "encorujadas", } \\
\text { diminuição do } \\
\text { consumo de } \\
\text { ração, } \\
\text { refugagem e } \\
\text { diarreia }\end{array}$ & - & - & + & + & - & + & - & - \\
\hline $342-1$ & $\begin{array}{c}18 \\
\text { semanas }\end{array}$ & Goiás & $26 / 05 / 2009$ & Sem sinais & - & - & - & - & - & + & - & - \\
\hline $342-4$ & $\begin{array}{c}18 \\
\text { semanas }\end{array}$ & Goiás & 26/05/2009 & Sem sinais & - & - & + & - & + & - & + & - \\
\hline $342-7$ & $\begin{array}{c}18 \\
\text { semanas }\end{array}$ & Goiás & $26 / 05 / 2009$ & Sem sinais & - & - & + & - & - & + & + & - \\
\hline $342-10$ & $\begin{array}{c}18 \\
\text { semanas }\end{array}$ & Goiás & $26 / 05 / 2009$ & Sem sinais & - & - & + & - & - & + & + & - \\
\hline $342-13$ & $\begin{array}{c}18 \\
\text { semanas }\end{array}$ & Goiás & 26/05/2009 & Sem sinais & - & - & + & - & - & - & - & - \\
\hline $342-16$ & $\begin{array}{c}18 \\
\text { semanas }\end{array}$ & Goiás & 26/05/2009 & Sem sinais & - & - & - & - & + & - & - & - \\
\hline $342-19$ & $\begin{array}{c}18 \\
\text { semanas }\end{array}$ & Goiás & 26/05/2009 & Sem sinais & - & - & - & - & + & - & - & - \\
\hline $343-1$ & $\begin{array}{c}18 \\
\text { semanas } \\
\end{array}$ & Goiás & $26 / 05 / 2009$ & Sem sinais & - & - & - & - & - & + & - & - \\
\hline $343-4$ & $\begin{array}{c}18 \\
\text { semanas }\end{array}$ & Goiás & 26/05/2009 & Sem sinais & - & - & - & - & - & - & - & - \\
\hline $343-7$ & $\begin{array}{c}18 \\
\text { semanas }\end{array}$ & Goiás & 26/05/2009 & Sem sinais & - & - & - & - & - & - & - & - \\
\hline $343-10$ & $\begin{array}{c}18 \\
\text { semanas }\end{array}$ & Goiás & 26/05/2009 & Sem sinais & - & - & - & - & - & - & - & - \\
\hline
\end{tabular}




\begin{tabular}{|c|c|c|c|c|c|c|c|c|c|c|c|c|}
\hline Amostra & Idade & Localidade & $\begin{array}{c}\text { Data da } \\
\text { coleta }\end{array}$ & Sinais clínicos & TAV & HEV & $\begin{array}{c}\text { TAstV } \\
-1 \\
\end{array}$ & $\begin{array}{c}\text { TAstV } \\
-2 \\
\end{array}$ & ANV & TCoV & Reovirus & Rotavirus \\
\hline $343-13$ & $\begin{array}{c}18 \\
\text { semanas }\end{array}$ & Goiás & 26/05/2009 & Sem sinais & - & - & - & + & - & - & - & - \\
\hline $343-16$ & $\begin{array}{c}18 \\
\text { semanas }\end{array}$ & Goiás & 26/05/2009 & Sem sinais & - & - & - & - & - & - & - & - \\
\hline $343-19$ & $\begin{array}{c}18 \\
\text { semanas }\end{array}$ & Goiás & 26/05/2009 & Sem sinais & - & - & - & + & + & - & - & - \\
\hline $347-1$ & $\begin{array}{c}18 \\
\text { semanas }\end{array}$ & Goiás & $26 / 05 / 2009$ & Sem sinais & - & - & + & - & + & + & - & + \\
\hline $347-2$ & $\begin{array}{c}18 \\
\text { semanas }\end{array}$ & Goiás & $26 / 05 / 2009$ & Sem sinais & - & - & + & - & - & - & - & + \\
\hline $347-4$ & $\begin{array}{c}18 \\
\text { semanas }\end{array}$ & Goiás & 26/05/2009 & Sem sinais & - & - & + & + & + & + & - & + \\
\hline $347-6$ & $\begin{array}{c}18 \\
\text { semanas }\end{array}$ & Goiás & 26/05/2009 & Sem sinais & - & - & + & + & + & + & - & + \\
\hline $\begin{array}{c}\text { 350-1A } \\
\text { (intestino } \\
\text { ) }\end{array}$ & 80 dias & Chapecó-SC & 02/06/2009 & Mortalidade alta & - & - & + & + & - & - & - & + \\
\hline $\begin{array}{l}\text { 350-1B } \\
\text { (fezes) }\end{array}$ & 80 dias & Chapecó-SC & 02/06/2009 & Mortalidade alta & - & - & + & + & - & + & - & + \\
\hline $\begin{array}{c}\text { 350-2A } \\
\text { (intestino } \\
\text { ) }\end{array}$ & 80 dias & Chapecó-SC & 02/06/2009 & Mortalidade alta & - & - & + & - & - & - & - & + \\
\hline $\begin{array}{l}350-2 B \\
\text { (fezes) }\end{array}$ & 80 dias & Chapecó-SC & 02/06/2009 & Mortalidade alta & - & - & + & + & - & - & - & - \\
\hline $\begin{array}{c}\text { 350-3A } \\
\text { (intestino } \\
\text { ) }\end{array}$ & 80 dias & Chapecó-SC & 02/06/2009 & Mortalidade alta & - & - & - & - & - & - & - & + \\
\hline $\begin{array}{l}350-3 \mathrm{~B} \\
\text { (fezes) }\end{array}$ & 80 dias & Chapecó-SC & 02/06/2009 & Mortalidade alta & - & - & + & - & - & - & - & + \\
\hline $\begin{array}{c}\text { 350-4A } \\
\text { (intestino } \\
\text { ) }\end{array}$ & 80 dias & Chapecó-SC & 02/06/2009 & Mortalidade alta & - & - & - & + & + & - & - & + \\
\hline $\begin{array}{l}350-4 \mathrm{~B} \\
\text { (fezes) }\end{array}$ & 80 dias & Chapecó-SC & 02/06/2009 & Mortalidade alta & - & - & - & + & - & - & - & - \\
\hline
\end{tabular}




\begin{tabular}{|c|c|c|c|c|c|c|c|c|c|c|c|c|}
\hline Amostra & Idade & Localidade & $\begin{array}{c}\text { Data da } \\
\text { coleta }\end{array}$ & Sinais clínicos & TAV & HEV & $\begin{array}{c}\text { TAstV } \\
-1\end{array}$ & $\begin{array}{c}\text { TAstV } \\
-2\end{array}$ & ANV & TCoV & Reovirus & Rotavirus \\
\hline $351-1 A$ & 13 dias & Chapecó-SC & 02/06/2009 & $\begin{array}{c}\text { Emagrecimento } \\
\text { progressivo, } \\
\text { diarreia, } \\
\text { fragilidade } \\
\text { intestinal }\end{array}$ & - & - & + & + & + & + & - & - \\
\hline $351-1 B$ & 13 dias & Chapecó-SC & 02/06/2009 & $\begin{array}{c}\text { Emagrecimento } \\
\text { progressivo, } \\
\text { diarreia, } \\
\text { fragilidade } \\
\text { intestinal }\end{array}$ & - & - & + & + & + & + & - & - \\
\hline $352-1$ & $\begin{array}{c}18 \\
\text { semanas }\end{array}$ & Goiás & 03/06/2009 & Sem sinais & - & - & - & - & - & - & - & + \\
\hline $352-4$ & $\begin{array}{c}18 \\
\text { semanas }\end{array}$ & Goiás & 03/06/2009 & Sem sinais & - & - & - & - & - & - & - & - \\
\hline $352-5$ & $\begin{array}{c}18 \\
\text { semanas }\end{array}$ & Goiás & 03/06/2009 & Sem sinais & - & - & + & + & - & - & - & - \\
\hline $352-9$ & $\begin{array}{c}18 \\
\text { semanas } \\
\end{array}$ & Goiás & 03/06/2009 & Sem sinais & - & - & - & - & - & - & - & + \\
\hline $352-12$ & $\begin{array}{c}18 \\
\text { semanas }\end{array}$ & Goiás & 03/06/2009 & Sem sinais & - & - & + & - & - & + & - & + \\
\hline $352-13$ & $\begin{array}{c}18 \\
\text { semanas }\end{array}$ & Goiás & 03/06/2009 & Sem sinais & - & - & - & - & - & - & - & + \\
\hline $352-16$ & $\begin{array}{c}18 \\
\text { semanas }\end{array}$ & Goiás & 03/06/2009 & Sem sinais & - & - & - & - & - & - & - & + \\
\hline $352-20$ & $\begin{array}{c}18 \\
\text { semanas }\end{array}$ & Goiás & 03/06/2009 & Sem sinais & - & - & + & - & - & - & - & + \\
\hline
\end{tabular}

